Published in final edited form as:

Cochrane Database Syst Rev. ; (2): CD003281. doi:10.1002/14651858.CD003281.pub3.

\title{
Stimulation of the wrist acupuncture point P6 for preventing postoperative nausea and vomiting
}

\author{
Anna Lee ${ }^{1}$ and Lawrence TY Fan ${ }^{1}$ \\ ${ }^{1}$ Department of Anaesthesia and Intensive Care, The Chinese University of Hong Kong, Shatin, \\ Hong Kong
}

\section{Abstract}

Background-Postoperative nausea and vomiting (PONV) are common complications following surgery and anaesthesia. Drugs to prevent PONV are only partially effective. An alternative approach is to stimulate the P6 acupoint on the wrist. This is an update of a Cochrane review first published in 2004.

Objectives-To determine the efficacy and safety of P6 acupoint stimulation in preventing PONV.

Search strategy-We searched CENTRAL (The Cochrane Library, Issue 3, 2008), MEDLINE (January 1966 to September 2008), EMBASE (January 1988 to September 2008), ISI Web of Science (January 1965 to September 2008), the National Library of Medicine publication list of acupuncture studies, and reference lists of articles.

Selection criteria-All randomized trials of techniques that stimulated the P6 acupoint compared with sham treatment or drug therapy for the prevention of PONV. Interventions used in these trials included acupuncture, electro-acupuncture, transcutaneous nerve stimulation, laser stimulation, capsicum plaster, an acu-stimulation device, and acupressure in patients undergoing surgery. Primary outcomes were the risks of nausea and vomiting. Secondary outcomes were the need for rescue antiemetic therapy and adverse effects.

Data collection and analysis-Two review authors independently assessed trial quality and extracted the data. We collected adverse effect information from the trials. We used a randomeffects model and reported relative risk (RR) with associated 95\% confidence intervals (95\% CI).

Main results-We included 40 trials involving 4858 participants; four trials reported adequate allocation concealment. Twelve trials did not report all outcomes. Compared with sham treatment P6 acupoint stimulation significantly reduced: nausea (RR 0.71, 95\% CI 0.61 to 0.83 ); vomiting (RR $0.70,95 \%$ CI 0.59 to 0.83 ), and the need for rescue antiemetics (RR $0.69,95 \%$ CI 0.57 to

Copyright $(92011$ The Cochrane Collaboration. Published by John Wiley \& Sons, Ltd.

Contact address: Anna Lee, Department of Anaesthesia and Intensive Care, The Chinese University of Hong Kong, Prince of Wales Hospital, Shatin, Hong Kong. annalee@ cuhk.edu.hk.

CONTRIBUTIONS OF AUTHORS

Anna Lee (AL) initiated and designed the review, extracted the data, conducted statistical analyses, wrote the first draft of the review, and incorporated comments from Mary Done, Anesthesia and Analgesia, and Cochrane peer reviewers into the final version (Lee 2004). Lawrence Fan provided comments on data extraction forms, extracted the data, and commented on all drafts of this updated review.

DECLARATIONS OF INTEREST

None known

DIFFERENCES BETWEEN PROTOCOL AND REVIEW

This updated review also assesses the differences in risk of PONV after combination P6 acupoint stimulation and antiemetic drugs with sham treatment 
$0.83)$. Heterogeneity among trials was moderate. There was no clear difference in the effectiveness of P6 acupoint stimulation for adults and children; or for invasive and noninvasive acupoint stimulation. There was no evidence of difference between P6 acupoint stimulation and antiemetic drugs in the risk of nausea (RR $0.82,95 \%$ CI 0.60 to 1.13 ), vomiting (RR $1.01,95 \%$ CI 0.77 to 1.31 ), or the need for rescue antiemetics (RR $0.82,95 \%$ CI 0.59 to 1.13). The side effects associated with P6 acupoint stimulation were minor. There was no evidence of publication bias from contour-enhanced funnel plots.

Authors' conclusions-P6 acupoint stimulation prevented PONV. There was no reliable evidence for differences in risks of postoperative nausea or vomiting after P6 acupoint stimulation compared to antiemetic drugs.

\section{Medical Subject Headings (MeSH)}

*Acupuncture Points; *Wrist; Antiemetics [therapeutic use]; Postoperative Nausea and Vomiting [*prevention \& control]; Randomized Controlled Trials as Topic

\section{MeSH check words}

Humans

\section{PLAIN LANGUAGE SUMMARY}

\section{P6 acupoint stimulation prevents postoperative nausea and vomiting with few side effects}

Postoperative nausea and vomiting (PONV) are two of the most common complications after anaesthesia and surgery. Drugs are only partially effective in preventing PONV and may cause adverse effects. Alternative methods, such as stimulating an acupuncture point on the wrist (P6 acupoint stimulation), have been studied in many trials. The use of P6 acupoint stimulation can reduce the risk of nausea and vomiting after surgery, with minimal side effects. The risks of postoperative nausea and vomiting were similar after P6 acupoint stimulation and antiemetic drugs.

\section{SUMMARY OF FINDINGS FOR THE MAIN COMPARISON [Explanation]}

\begin{tabular}{|c|c|c|c|c|c|c|}
\hline \multicolumn{7}{|c|}{ Acupoint P6 stimulation versus sham to prevent postoperative nausea and vomiting } \\
\hline \multicolumn{7}{|c|}{ Patient or population: patients with a desire to prevent postoperative nausea and vomiting } \\
\hline \multicolumn{7}{|l|}{ Settings: Surgery } \\
\hline \multicolumn{7}{|c|}{ Intervention: Acupoint P6 stimulation versus sham } \\
\hline \multirow[t]{3}{*}{ Outcomes } & \multicolumn{2}{|c|}{ Illustrative comparative risks ${ }^{*}(95 \% \mathrm{CI})$} & \multirow{2}{*}{$\begin{array}{l}\text { Relative effect } \\
(95 \% \text { CI })\end{array}$} & \multirow{2}{*}{$\begin{array}{l}\text { No of } \\
\text { Participants } \\
\text { (studies) }\end{array}$} & \multirow{2}{*}{$\begin{array}{l}\text { Quality of } \\
\text { the evidence } \\
\text { (GRADE) }\end{array}$} & \multirow[t]{2}{*}{ Comments } \\
\hline & Assumed risk & Corresponding risk & & & & \\
\hline & Control & $\begin{array}{l}\text { Acupoint P6 } \\
\text { stimulation versus } \\
\text { sham }\end{array}$ & & & & \\
\hline \multirow[t]{4}{*}{ Nausea - All trials } & Low risk popu & & \multirow{4}{*}{$\begin{array}{l}\text { RR 0.71 } \\
(0.61 \text { to } 0.83)\end{array}$} & \multirow{4}{*}{$\begin{array}{l}2962 \\
(27)\end{array}$} & \multirow{4}{*}{$\begin{array}{l}\oplus \oplus \oplus \bigcirc \\
\text { moderate }^{2}\end{array}$} & \\
\hline & 100 per 1000 & $\begin{array}{l}71 \text { per } 1000 \\
(61 \text { to } 83)\end{array}$ & & & & \\
\hline & \multicolumn{2}{|c|}{ High risk population ${ }^{l}$} & & & & \\
\hline & 400 per 1000 & $\begin{array}{l}\mathbf{2 8 4} \text { per } \mathbf{1 0 0 0} \\
(244 \text { to } 332)\end{array}$ & & & & \\
\hline
\end{tabular}




\begin{tabular}{|c|c|c|c|c|c|}
\hline \multirow{4}{*}{$\begin{array}{l}\text { Vomiting - All } \\
\text { trials }\end{array}$} & \multicolumn{2}{|c|}{ Low risk population ${ }^{1}$} & \multirow{4}{*}{$\begin{array}{l}\text { RR } \mathbf{0 . 7} \\
(0.59 \text { to } 0.83)\end{array}$} & \multirow{4}{*}{$\begin{array}{l}3385 \\
(32)\end{array}$} & \multirow{4}{*}{$\begin{array}{l}\oplus \oplus \oplus \bigcirc \\
\text { moderate }^{2}\end{array}$} \\
\hline & 100 per 1000 & $\begin{array}{l}\mathbf{7 0} \text { per } \mathbf{1 0 0 0} \\
(59 \text { to } 83)\end{array}$ & & & \\
\hline & \multicolumn{2}{|c|}{ High risk population ${ }^{l}$} & & & \\
\hline & 400 per 1000 & $\begin{array}{l}\mathbf{2 8 0} \text { per } 1000 \\
(236 \text { to } 332)\end{array}$ & & & \\
\hline \multirow[t]{2}{*}{ Rescue antiemetics } & \multicolumn{2}{|c|}{ Medium risk population } & \multirow{2}{*}{$\begin{array}{l}\text { RR 0.69 } \\
(0.57 \text { to } 0.83)\end{array}$} & \multirow{2}{*}{$\begin{array}{l}2661 \\
(26)\end{array}$} & \multirow{2}{*}{$\begin{array}{l}\oplus \oplus \oplus \bigcirc \\
\text { moderate }^{2}\end{array}$} \\
\hline & 363 per 1000 & $\begin{array}{l}\text { 250 per } 1000 \\
(207 \text { to } 301)\end{array}$ & & & \\
\hline Adverse effects $^{3}$ & See comment & See comment & Not estimable ${ }^{3}$ & - & See comment \\
\hline \multicolumn{6}{|c|}{$\begin{array}{l}\text { The basis for the assumed risk (e.g. the median control group risk across studies) is provided in footnotes. The } \\
\text { corresponding risk (and its } 95 \% \text { confidence interval) is based on the assumed risk in the comparison group and the } \\
\text { relative effect of the intervention (and its } 95 \% \mathrm{CI} \text { ). }\end{array}$} \\
\hline \multicolumn{6}{|c|}{ CI: Confidence interval; RR: Risk ratio; } \\
\hline \multicolumn{6}{|c|}{ GRADE Working Group grades of evidance } \\
\hline \multirow{2}{*}{\multicolumn{6}{|c|}{$\begin{array}{l}\text { High quality: Further research is very unlikely to change our confidence in the estimate of effect. } \\
\text { Moderate quality: Further research is likely to have an important impact on our confidence in the estimate of effect and } \\
\text { may change the estimate. }\end{array}$}} \\
\hline & & & & & \\
\hline \multicolumn{6}{|c|}{$\begin{array}{l}\text { Low quality: Further research is very likely to have an important impact on our confidence in the estimate of effect and is } \\
\text { likely to change the estimate. }\end{array}$} \\
\hline \multicolumn{6}{|c|}{ Very low quality: We are very uncertain about the estimate. } \\
\hline \multicolumn{6}{|c|}{$\begin{array}{l}1 \text { No risk factors for postoperative nausea and vomiting typically have control rates of } 10 \% \text {; most studies in this systematic } \\
\text { review had high risk patients with two or more risk factors for postoperative nausea and vomiting, therefore we assumed a } \\
\text { risk of } 40 \% \text {. }\end{array}$} \\
\hline \multicolumn{6}{|c|}{${ }^{2}$ Unexplained moderate heterogeneity among trials even after subgroup analyses. } \\
\hline
\end{tabular}

\section{BACKGROUND}

Postoperative nausea and vomiting (PONV) are common complaints after general, regional, or local anaesthesia (Watcha 1992), with incidences up to 80\% (Sadhasivam 1999). Drug therapy is only partially effective in preventing or treating PONV (Gin 1994). A systematic review of antiemetic drugs for PONV (Carlisle 2006) showed that eight drugs effectively prevented PONV when compared to placebo: droperidol, metoclopramide, ondansetron, tropisetron, dolasetron, dexamethasone, cyclizine, and granisetron. The relative risks varied between 0.60 and 0.80, depending on the drug and the outcome (Carlisle 2006). Evidence for side effects was sparse: droperidol was sedative (RR 1.32) and headache was more common after ondansetron (RR 1.16) (Carlisle 2006). More recently, a multidisciplinary panel of experts produced guidelines for the prevention or minimization of PONV using prophylactic or rescue therapy, either separately or in combination (Gan 2007).

As anaesthetists continue to search for more cost-effective approaches to improving patient outcomes, attention has focused on simple, inexpensive, and non-invasive methods to prevent PONV. Concern about the cost and side effects of drugs has led to interest in the use of alternative approaches to preventing emesis.

Various non-pharmacological techniques have been examined in trials as alternatives to antiemetic drugs; these include acupuncture, electro-acupuncture, laser acupuncture, transcutaneous electrical nerve stimulation (TENS), acupoint stimulation, acupressure, and 
capsicum plaster. Most non-pharmacological studies have focused on stimulation of the wrist at the 'Pericardium (P6) acupuncture point' to reduce nausea and vomiting. The P6 acupoint lies between the tendons of the palmaris longus and flexor carpi radialis muscles, 4 $\mathrm{cm}$ proximal to the wrist crease (Yang 1993). The mechanism by which P6 acupoint stimulation prevents PONV has not been established. Other acupoints believed to prevent PONVinclude Shenmen (H7) (Ming 2002) and Shang Wen (CV13) (Somri 2001).

Both the role and efficacy of P6 acupoint stimulation in the prevention of PONV are unclear. For example, P6 acupoint stimulation significantly reduced the risk of PONV in some studies (Amir 2007; Butkovic 2005; Ho 1996; Rusy 2002; Turgut 2007; Wang 2002) but not in others (Agarwal 2000; Allen 1994; Barsoum 1990; Misra 2005; Shenkman 1999). One systematic review (Vickers 1996), using a 'vote counting' approach, suggested that acupuncture may not be effective in the prevention of PONV. However, the vote counting approach is not considered an acceptable method of summarizing the results of a systematic review (Petitti 1994).

Our previous systematic review of trials (Lee 1999), including trials published up to 1997, showed no difference between P6 acupoint stimulation and commonly used antiemetic drugs in preventing PONV after surgery. This review also indicated that the technique was more effective than placebo (sham treatment or no treatment) in preventing PONV in adults but not in children. However, these results in children were questionable as they were based largely on trials in which P6 acupoint stimulation occurred while the central nervous system was depressed by general anaesthesia (White 1999). Another major limitation of our earlier review was that we included both no treatment and sham treatment groups. Therefore, we may have overestimated the treatment effect of P6 acupoint stimulation.

In the earlier version of this Cochrane review (Lee 2004) of 26 trials $(n=3347)$, we showed that there were significant reductions in the risks of nausea (RR 0.72 , $95 \% \mathrm{CI} 0.59$ to 0.89 ), vomiting (RR 0.71, 95\% CI 0.56 to 0.91), and the need for rescue antiemetics (RR 0.76, $95 \%$ CI 0.58 to 1.00) in the P6 acupoint stimulation group compared with the sham treatment group. Publication bias may have affected the RR estimated for postoperative nausea but not for vomiting (Lee 2006).

\section{OBJECTIVES}

To assess the prevention of nausea, vomiting, or requirement for rescue antiemesis (PONV) by acupoint stimulation.

We assessed whether the risks of PONV were different:

1. after P6 acupoint stimulation compared to sham treatment, where 'sham treatment' was defined as either a device applied in a non-P6 location, or any attempt to imitate (give the illusion of) P6 acupoint stimulation;

2. after P6 acupoint stimulation for adults compared with children;

3. for invasive P6 acupoint stimulation compared with noninvasive stimulation, where 'invasive P6 acupoint stimulation' was defined as penetration of the skin at P6 acupoint (with manual rotation of acupuncture needle, electrical stimulation of acupuncture needle) and 'noninvasive P6 acupoint stimulation' was defined as techniques that did not require skin penetration at the P6 acupoint (acupressure, transcutaneous electrical stimulation, laser directed at P6 acupoint, capsicum plaster at $\mathrm{P6}$ acupoint);

4. after P6 acupoint stimulation in trials with low risk of bias compared with unclear or high risk of bias; 
5. after P6 acupoint stimulation compared with antiemetic drugs;

6. after a combination of $\mathrm{P} 6$ acupoint stimulation and antiemetic drug compared with sham treatment.

We assessed these effects because the National Institutes of Health (NIH) issued a statement that 'acupuncture may be useful as an adjunct treatment or an acceptable alternative or included in a comprehensive management program for many medical conditions' (NIH 1997).

\section{METHODS}

\section{Criteria for considering studies for this review}

Types of studies-All randomized controlled trials (RCTs) of techniques intended to stimulate the P6 acupoint, compared with either sham treatment or antiemetic drugs, for the prevention of PONV. 'Sham treatment' was defined as a device applied in a non-P6 location, or any attempt to imitate (give the illusion of) P6 acupoint stimulation. Therefore, for trials that assessed acupressure wristbands, wristbands without studs placed at the P6 acupoint were considered as adequate sham treatment and these trials were included in the review.

Types of participants-All surgical patients without age limitation. The age limits for children were defined by each study.

Types of interventions-Techniques intended to stimulate the P6 acupoint: acupuncture, electro-acupuncture, laser acupuncture, transcutaneous electrical stimulation, an acustimulation device, acupressure, and capsicum plaster; versus sham treatment or drug therapy for the prevention of PONV. These diverse techniques were considered as one entity in the main analysis, consistent with the concept that stimulating the correct acupuncture point is more important than the nature of the stimulus (Mann 1987). There was no restriction on the duration of P6 acupoint stimulation or when it was applied.

Types of outcome measures-We did separate meta-analyses for each of the following primary and secondary outcomes. Trials could report more than one primary or secondary outcome.

\section{Primary outcomes}

1. Risk of postoperative nausea.

2. Risks of postoperative vomiting. This was defined as either retching or vomiting, or both.

Postoperative nausea and vomiting were not combined as we could not be certain that patients who vomited were also nauseated. If the authors reported several incidences of the outcome measure (for example 0 to 6 hours, 6 to 24 hours, 0 to 24 hours), the longest cumulative follow-up data from the end of surgery were used (in this case, 0 to 24 hours).

\section{Secondary outcomes}

1. Risk of patients requiring a rescue antiemetic drug.

2. Risk of side effects.

\section{Search methods for identification of studies}

Electronic searches-We searched the following for relevant trials. 
- The Cochrane Central Register of Controlled Trials (CENTRAL) (The Cochrane Library, Issue 3, 2008), in Appendix 1.

- Electronic databases: MEDLINE (January 1966 to September 2008), in Appendix 2; EMBASE (January 1988 to September 2008), in Appendix 3; ISI Web of Science (January 1965 to September 2008), in Appendix 4; and National Library of Medicine publication list of acupuncture studies (http://www.nlm.nih.gov/pubs/cbm/acupuncture.html).

- Reference lists of relevant articles, reviews, and trials.

We combined the following MeSH and text words with the filters for identifying randomized controlled trials: 'postoperative complications', 'nausea and vomiting', 'acupuncture', 'acupuncture therapy', 'acupuncture points', 'acupressure', 'transcutaneous electric nerve stimulator', and 'electro-acupuncture'.

There was no language restriction. We excluded studies of P6 acupoint stimulation to treat established PONV, or to prevent intraoperative nausea or vomiting.

Searching other resources-We did not search for conference proceedings or seek unpublished trials. Grey literature has not been peer-reviewed and there is some evidence that it is of lower quality than published studies (McAuley 2000).

\section{Data collection and analysis}

We selected trials identified by our search that fulfilled our inclusion criteria. There was no disagreement between authors about inclusion and exclusion of studies for this review. We examined all selected trials for duplicate data; where we found duplication, we used the results of the main trial report. We extracted data independently, using a standardized data collection form, and we resolved any discrepancies in data extraction by discussion. We assessed the quality of the included trials independently, under open conditions. We graded the risk of bias for each study in the domains of sequence generation; allocation concealment; blinding of participants, healthcare providers, and outcome assessors; incomplete outcome data; selective outcome reporting; and comparison of baseline characteristics for each group in a 'Risk of bias' table (Higgins 2008). We graded each domain as yes (low risk of bias), no (high risk of bias), or unclear (uncertain risk of bias) according to the criteria outlined in the Cochrane Handbook for Systematic Reviews of Interventions (Higgins 2008).

We collected data on the type, duration, and timing of P6 acupoint stimulation, as well as the type and dose of prophylactic antiemetic drug. We recorded details of the patient population and type of surgery. We did not consider factors such as the severity of PONV or the number of episodes of vomiting.

We used the random-effects model to combine data, as we expected that the treatments and conditions in these trials would be heterogeneous. This model incorporates both betweenstudy (different treatment effects) and within-study (sampling error) variability (Mosteller 1996). We calculated the pooled relative risk (RR) and 95\% confidence interval (95\% CI), and analysed heterogeneity using the $\mathrm{I}^{2}$ statistic as a measure of the proportion of total variation in the estimates of treatment effect that is due to heterogeneity between studies. We conducted sensitivity analyses to estimate the robustness of results according to sequence generation, allocation concealment, blinding of outcome assessor (adequate versus inadequate or unclear), selective reporting (adequate versus inadequate or unclear), and control event rate $(\leq 20 \%,>20 \%)$. We undertook exploratory a priori subgroup analyses, which included trials in adults versus trials in children and trials according to type of P6 
acupoint stimulation (invasive versus noninvasive). To test whether the subgroups were different from one another, we tested the interaction using the technique outlined by Altman and Bland (Altman 2003).

We used the contour-enhanced funnel plot to differentiate asymmetry due to publication bias from that due to other factors (Peters 2008), using STATA statistical software (Stata Corporation, College Station, Texas, version 10). Contour-enhanced funnel plots display the area of statistical significance on a funnel plot (Peters 2008) to improve the correct identification of the presence or absence of publication bias. This was used in conjunction with the 'trim and fill' method (Duval 2000) to inform the likely location of missing studies, using STATA statistical software (Stata Corporation, College Station, Texas, version 10), as suggested by Peters (Peters 2008). Publication bias would be expected when the usual funnel plot is asymmetrical but assessment of the contour-enhanced funnel plot indicates that missing studies are located where nonsignificant studies would be plotted (Peters 2008).

We estimated the number needed to treat (NNT) for different baseline risk for nausea and vomiting using the RR (Smeeth 1999) to assess whether P6 acupoint stimulation is worthwhile for individuals. We estimated the $95 \% \mathrm{CI}$ around the number needed to treat using the method outlined by Altman (Altman 1998).

\section{RESULTS}

\section{Description of studies}

See: Characteristics of included studies; Characteristics of excluded studies.

The search identified 67 trials of P6 acupoint stimulation for PONV. The flow chart (Figure 1) shows the results of the literature search (the number of hits) and the culling process to reduce the total to 40 included studies.

Included studies-We included 40 trials, involving 4858 participants, conducted between 1986 and 2008. All trials but one (Gieron 1993) were published in English. Most trials recruited healthy adults undergoing elective surgery. Seven trials recruited children (Butkovic 2005; Lewis 1991; Rusy 2002; Schlager 1998; Shenkman 1999; Wang 2002; Yentis 1992). One trial recruited both children and adults (Amir 2007). Most participants had general anaesthesia. Women having elective Caesarean delivery received spinal anaesthesia in four studies (Duggal 1998; Habib 2006; Harmon 2000; Ho 1996).

There were 10 types of P6 acupoint stimulation: needle acupuncture (Dundee 1986; Dundee 1989; Sharma 2007; Streitberger 2004; Yentis 1992); infiltration of dextrose (Tavlan 1996; Wang 2002; Yang 1993); semipermanent needles (Andrzejowski 1996); electrical stimulation of needles (Amir 2007; Dundee 1989; Ho 1989; Rusy 2002); transcutaneous electrical nerve stimulation (Fassoulaki 1993; Gan 2004; Habib 2006; Ho 1989); laser stimulation (Butkovic 2005; Schlager 1998); an acu-stimulation device (White 2002; Zarate 2001); and acupressure (Agarwal 2000; Agarwal 2002; Alkaissi 1999; Alkaissi 2002; Allen 1994; Barsoum 1990; Duggal 1998; Ferrara-Love 1996; Gieron 1993; Harmon 1999;

Harmon 2000; Ho 1996; Klein 2004; Lewis 1991; Samad 2003; Schultz 2003; Turgut 2007). Two studies used conventional peripheral nerve stimulation (Arnberger 2007; Liu 2008). One trial each used: both acupressure and acupuncture (Shenkman 1999); and a capsicum plaster (Misra 2005). The type of surgery; type, timing, and duration of stimulation of the P6 acupoint; and the follow-up time for assessing PONV varied greatly.

P6 stimulation was compared with five antiemetic drugs: metoclopramide (Butkovic 2005; Dundee 1989); cyclizine (Dundee 1989); prochlorperazine (Barsoum 1990; Ho 1989); 
droperidol (Schultz 2003; Wang 2002; Yang 1993; Yentis 1992); and ondansetron (Agarwal 2002; Gan 2004; Misra 2005; Sharma 2007; Tavlan 1996; White 2002).

Excluded studies-We excluded 27 trials. Please see 'Characteristics of excluded studies' for more information.

\section{Risk of bias in included studies}

Allocation sequence was generated using a computer-generated random numbers table (Agarwal 2000; Arnberger 2007; Gan 2004; Harmon 1999; Ho 1996; Klein 2004; Misra 2005; White 2002; Zarate 2001), a table of random numbers (Agarwal 2002; Duggal 1998; Liu 2008; Samad 2003; Schultz 2003), a block design procedure (Rusy 2002), and a yoking randomization based on a computer-generated list (Wang 2002). Four of the 40 trials reported adequate allocation concealment (Arnberger 2007; Gan 2004; Schultz 2003; Streitberger 2004). In 34 trials the allocation concealment was unclear, and in one trial (Ferrara-Love 1996) it was inadequate. Patients were not blinded in one study (Sharma 2007) because acupuncture needles inserted before induction of anaesthesia had to be kept in situ in the operating room in two of the three intervention groups. There was no blinding of healthcare providers in two studies (Arnberger 2007; Sharma 2007). The outcome assessor was not blinded in two studies (Gieron 1993; Sharma 2007). Twelve trials did not report all four outcomes: postoperative nausea, postoperative vomiting, rescue antiemetic drugs, and adverse events in their studies (Alkaissi 1999; Allen 1994; Barsoum 1990; Butkovic 2005; Fassoulaki 1993; Ferrara-Love 1996; Habib 2006; Harmon 2000; Ho 1989; Lewis 1991; Schultz 2003; Yang 1993). All studies except one (Dundee 1989) reported the betweengroup comparisons of baseline characteristics. A 'Risk of bias' graph captures the review authors' judgements about each risk of bias item, presented as percentages across all included trials (Figure 2). A 'Risk of bias' summary captures the review authors' judgements about each risk of bias item for each included trial (Figure 3). There was one study with a low risk of bias (Gan 2004), as all key domains were rated 'Yes'. Of the 16 studies with a high risk of bias (one or more key domains were rated 'No'), 12 of these were due to selective reporting. The risk of bias in the remaining 23 studies was unclear.

\section{Effects of interventions}

See: Summary of findings for the main comparison; Summary of findings 2

\section{P6 acupoint stimulation versus sham treatment}

Nausea: (see Analysis 1.1)

Twenty-seven trials examined P6 acupoint stimulation for the prevention of nausea, in a total of 2962 participants (Analysis 1.1). P6 acupoint stimulation reduced the risk of nausea (RR $0.71,95 \%$ CI 0.61 to 0.83 ) but there was moderate heterogeneity $\left(\mathrm{I}^{2}=60 \%\right.$ ) (Figure 4 ). The 'trim and fill' method did not trim or add any more studies to the contour-enhanced funnel plot (Figure 5). The estimated number needed to treat for different baseline risks of nausea is shown in 'Additional Table 1'.

There was no evidence of an interaction between the estimated effect of P6 stimulation and the sensitivity and subgroup analyses that were prespecified: adequate compared with unclear or inadequate sequence generation (Analyses 1.1.2, 1.1.3: $\mathrm{z}$ statistic $-0.79, \mathrm{P}=$ 0.43 ); allocation concealment (Analyses 1.1.4, 1.1.5: z statistic 0.32, $\mathrm{P}=0.75$ ); blinding of outcome assessor (Analyses 1.1.6, 1.1.7: $\mathrm{z}$ statistic $-1.64, \mathrm{P}=0.10$ ); selective reporting (Analyses 1.1.8, 1.1.9: $\mathrm{z}$ statistic $-0.72, \mathrm{P}=0.47$ ); control event rates $\leq 20 \%$ or more than $20 \%$ (Analyses 1.1.10, 1.1.11: $\mathrm{z}$ statistic $0.70, \mathrm{P}=0.48$ ); children compared with adults 
(Analyses 1.1.12, 1.1.13: $\mathrm{z}$ statistic $-1.13, \mathrm{P}=0.26$ ); invasive compared with noninvasive P6 acupoint stimulation (Analyses 1.1.14, 1.1.15: $\mathrm{z}$ statistic $-0.63, \mathrm{P}=0.53$ ).

Vomiting:(see Analysis 1.2)

Thirty-two trials examined P6 acupoint stimulation for the prevention of vomiting, in 3385 participants. P6 acupoint stimulation reduced the risk of vomiting (RR $0.70,95 \% \mathrm{CI} 0.59$ to 0.83 ) but there was moderate heterogeneity $\left(\mathrm{I}^{2}=53 \%\right)$ (Figure 6). The 'trim and fill' method did not trim or add any more studies to the contour-enhanced funnel plot (Figure 7). The estimated number needed to treat for different baseline risks of vomiting is shown in 'Additional Table 1'.

There was no evidence of an interaction between the estimated effect of P6 stimulation and the prespecified sensitivity and subgroup analyses: adequate compared with unclear or inadequate sequence generation (Analyses 1.1.2, 1.1.3: $\mathrm{z}$ statistic 0.42, $\mathrm{P}=0.68$ ); allocation concealment (Analyses 1.1.4, 1.1.5: $\mathrm{z}$ statistic $0.25, \mathrm{P}=0.80$ ); blinding of outcome assessor (Analyses 1.1.6, 1.1.7: $\mathrm{z}$ statistic $0, \mathrm{P}=1.00$ ); selective reporting (Analyses 1.1.8, 1.1.9: $\mathrm{z}$ statistic $0.24, \mathrm{P}=0.81$ ); control event rates $\leq 20 \%$ or more than $20 \%$ (Analyses 1.1.10, 1.1.11: $\mathrm{z}$ statistic $1.10, \mathrm{P}=0.27$ ); children compared with adults (Analyses 1.1.12, 1.1.13: $\mathrm{z}$ statistic $-0.41, \mathrm{P}=0.68$ ); invasive compared with noninvasive P6 acupoint stimulation (Analyses 1.1.14, 1.1.15, z statistic $-0.85, \mathrm{P}=0.40$ ).

\section{Rescue antiemetic: (Analysis 1.3)}

The risk that a rescue antiemetic was required was less after P6 stimulation than after sham treatment (RR $0.69,95 \%$ CI 0.57 to 0.83 ) (Figure 8). There was moderate heterogeneity (I ${ }^{2}$ $=43 \%$ ). Three trials did not specify the type of rescue antiemetic drug used (Alkaissi 2002; Duggal 1998; Ferrara-Love 1996). We included the data excluded by one trial for persistent vomiting (Fassoulaki 1993).

Side effects: Overall, the side effects associated with P6 acupoint stimulation were minor and self-limiting. No side effects were observed for patients receiving acupuncture (Dundee 1986; Dundee 1989; Sharma 2007); acupressure, in several trials (Agarwal 2000; Agarwal 2002; Gieron 1993; Harmon 1999; Ho 1996; Klein 2004; Lewis 1991); or transcutaneous electro-acupoint stimulation by a peripheral nerve stimulator (Liu 2008). Haematomas occurred in one patient in the acupuncture group and in two patients in the placebo acupuncture group (Streitberger 2004). Although no side effects were reported in associated with an acu-stimulation device (White 2002), another trial reported mild cutaneous irritation (Zarate 2001). Pain was reported at the acupuncture site in one trial (Yang 1993). There was no significant difference in the incidence of redness and irritation at the puncture site between P6 acupoint stimulation and sham treatment groups (Shenkman 1999). Patients complained of feeling tired and sleepy during electro-acupuncture stimulation (Ho 1989). Two trials (Alkaissi 2002; Duggal 1998) reported that acupressure bands felt uncomfortable; produced red indentation; or caused itching, headache and dizziness, swollen wrists, and blistering at the site of the button. One patient complained of mild irritation at the site of capsicum plaster application (Misra 2005).

\section{P6 acupoint stimulation versus antiemetic drug}

Nausea: (Analysis 2.1)

There was no difference in the risk of postoperative nausea for P6 acupoint stimulation compared to pooled antiemetic drugs (Analysis 2.1.6: RR 0.82, 95\% CI 0.60 to 1.13) (Agarwal 2002; Dundee 1989; Gan 2004; Misra 2005; Schultz 2003; Sharma 2007; Tavlan 
1996; Wang 2002; White 2002). There was minor heterogeneity between the trials $\left(\mathrm{I}^{2}=\right.$ $37 \%$ ) (Figure 9). The 'trim and fill' method did not trim or add any more studies to the contour-enhanced funnel plot (Figure 10). The level of sequence generation modified the estimated effect of P6 stimulation on nausea (Analyses 2.1.7, 2.1.8: z statistic 2.02, P = $0.04)$. There was no evidence of any interaction between the estimated effect of P6 stimulation and the prespecified sensitivity and subgroup analyses: allocation concealment (Analyses 2.1.9, 2.1.10: $\mathrm{z}$ statistic 0.27, $\mathrm{P}=0.79$ ); blinding of outcome assessor (Analyses 2.1.11, 2.1.12: $\mathrm{z}$ statistic $-1.03, \mathrm{P}=0.30$ ); selective reporting (Analyses 2.1.13, 2.1.14: $\mathrm{z}$ statistic $0.15, \mathrm{P}=0.88)$.

Vomiting:(Analysis 2.2)

There was no difference in the risk of postoperative vomiting for P6 acupoint stimulation compared to pooled antiemetic drugs (Analysis 2.2.6: RR 1.01, 95\% CI 0.77 to 1.31 ) (Agarwal 2002; Barsoum 1990; Butkovic 2005; Dundee 1989; Gan 2004; Ho 1989; Misra 2005; Schultz 2003; Sharma 2007; Tavlan 1996; Wang 2002; White 2002; Yang 1993; Yentis 1992). Trial results were homogeneous $\left(\mathrm{I}^{2}=0 \%\right)$ (Figure 11). The 'trim and fill' method did not trim or add any more studies to the contour-enhanced funnel plot (Figure 12). There was no evidence of an interaction between the effect of P6 stimulation and the prespecified sensitivity and subgroup analyses: sequence generation (Analyses 2.2.7, 2.2.8: $\mathrm{z}$ statistic -0.04, $\mathrm{P}=0.97$ ); allocation concealment (Analyses 2.2.9, 2.2.10: $\mathrm{z}$ statistic 0.64, $\mathrm{P}$ $=0.52$ ); blinding of outcome assessor (Analyses 2.2.11, 2.2.12: $\mathrm{z}$ statistic $-0.18, \mathrm{P}=0.86$ ); selective reporting (Analyses 2.2.13, 2.2.14: $\mathrm{z}$ statistic $-0.56, \mathrm{P}=0.58$ ).

Rescue antiemetic: (Analysis 2.3)

There was no difference in the risk of requiring rescue antiemetics for P6 acupoint stimulation compared to pooled antiemetic drugs (RR 0.82, 95\% CI 0.59 to 1.13) (Agarwal 2002; Butkovic 2005; Gan 2004; Misra 2005; Sharma 2007; Wang 2002; White 2002). Trial results were homogeneous $\left(\mathrm{I}^{2}=0 \%\right)$ (Figure 13$)$.

Side effects: Restlessness was less frequent in the acupuncture group than after roperidol (RR $0.47,95 \%$ CI 0.26 to 0.87 ) (Yentis 1992).

P6 acupoint stimulation and antiemetic combination versus sham-One trial examined this comparison (Schultz 2003). There was no difference between groups for the risk of nausea (RR 1.19, 95\% CI 0.91 to 1.55 ) and vomiting (RR 1.18, 95\% CI 0.63 to 2.21).

ADDITIONAL SUMMARY OF FINDINGS [Explanation]

\begin{tabular}{|c|c|c|c|c|c|c|}
\hline \multicolumn{7}{|c|}{ Acupoint P6 stimulation versus sham to prevent postoperative nausea and vomiting } \\
\hline \multicolumn{7}{|c|}{ Patient or population: patients with a desire to prevent postoperative nausea and vomiting } \\
\hline \multicolumn{7}{|c|}{ Settings: Surgery } \\
\hline \multicolumn{7}{|c|}{ Intervention: Acupoint P6 stimulation versus antiemetic } \\
\hline \multirow[t]{3}{*}{ Outcomes } & \multicolumn{2}{|c|}{ Illustrative comparative risks ${ }^{*}(95 \% \mathrm{CI})$} & \multirow{2}{*}{$\begin{array}{l}\text { Relative } \\
\text { effect } \\
\text { (95\% } \\
\text { CI) }\end{array}$} & \multirow{2}{*}{$\begin{array}{l}\text { No of } \\
\text { Participants } \\
\text { (studies) }\end{array}$} & \multirow{2}{*}{$\begin{array}{l}\text { Quality of } \\
\text { the } \\
\text { evidence } \\
\text { (GRADE) }\end{array}$} & \multirow[t]{2}{*}{ Comments } \\
\hline & Assumed risk & Corresponding risk & & & & \\
\hline & Control & $\begin{array}{l}\text { Acupoint P6 } \\
\text { stimulation versus } \\
\text { sham }\end{array}$ & & & & \\
\hline
\end{tabular}




\begin{tabular}{|c|c|c|c|c|c|}
\hline \multirow{4}{*}{$\begin{array}{l}\text { Nausea - All } \\
\text { antiemetics } \\
\text { combined }\end{array}$} & \multicolumn{2}{|c|}{ Low risk population ${ }^{l}$} & \multirow{4}{*}{$\begin{array}{l}\text { RR 0.82 } \\
(0.6 \text { to } \\
1.13)\end{array}$} & \multirow{4}{*}{$\begin{array}{l}660 \\
(9)\end{array}$} & \multirow{4}{*}{$\begin{array}{l}\oplus \oplus \oplus \bigcirc \\
\text { moderate }^{2}\end{array}$} \\
\hline & 100 per 1000 & $\begin{array}{l}82 \text { per } 1000 \\
(60 \text { to } 113)\end{array}$ & & & \\
\hline & \multicolumn{2}{|c|}{ High risk population 1} & & & \\
\hline & 400 per 1000 & $\begin{array}{l}\mathbf{3 2 8} \text { per } \mathbf{1 0 0 0} \\
(240 \text { to } 452)\end{array}$ & & & \\
\hline \multirow{4}{*}{$\begin{array}{l}\text { Vomiting - All } \\
\text { antiemetics } \\
\text { combined }\end{array}$} & \multicolumn{2}{|c|}{ Low risk population 1} & \multirow{4}{*}{$\begin{array}{l}\text { RR 1.01 } \\
(0.77 \text { to } \\
1.31)\end{array}$} & \multirow{4}{*}{$\begin{array}{l}1036 \\
(14)\end{array}$} & \multirow{4}{*}{$\begin{array}{l}\oplus \oplus \oplus \bigcirc \\
\text { moderate }^{2}\end{array}$} \\
\hline & 100 per 1000 & $\begin{array}{l}\mathbf{1 0 1} \text { per } \mathbf{1 0 0 0} \\
\text { (77 to } 131)\end{array}$ & & & \\
\hline & \multicolumn{2}{|c|}{ High risk population ${ }^{l}$} & & & \\
\hline & 400 per 1000 & $\begin{array}{l}\mathbf{4 0 4} \text { per } \mathbf{1 0 0 0} \\
(308 \text { to } 524)\end{array}$ & & & \\
\hline \multirow[t]{2}{*}{ Rescue antiemetic } & \multicolumn{2}{|c|}{ Medium risk population } & \multirow{2}{*}{$\begin{array}{l}\text { RR 0.82 } \\
(0.59 \text { to } \\
1.13)\end{array}$} & \multirow{2}{*}{$\begin{array}{l}527 \\
(7)\end{array}$} & \multirow{2}{*}{$\begin{array}{l}\oplus \oplus \bigoplus \bigcirc \\
\text { moderate }^{2}\end{array}$} \\
\hline & 180 per 1000 & $\begin{array}{l}\mathbf{1 4 8} \text { per } 1000 \\
(106 \text { to } 203)\end{array}$ & & & \\
\hline Adverse effects ${ }^{3}$ & 633 per 1000 & $\begin{array}{l}\mathbf{2 9 8} \text { per } \mathbf{1 0 0 0} \\
\text { (165 to } 551)\end{array}$ & $\begin{array}{l}\text { RR 0.47 } \\
(0.26 \text { to } \\
0.87)\end{array}$ & $\begin{array}{l}60 \\
(1)\end{array}$ & \\
\hline
\end{tabular}

The basis for the assumed risk (e.g. the median control group risk across studies) is provided in footnotes. The corresponding risk (and its 95\% confidence interval) is based on the assumed risk in the comparison group and the relative effect of the intervention (and its 95\% CI).

CI: Confidence interval; RR: Risk ratio;

GRADE Working Group grades of evidance

High quality: Further research is very unlikely to change our confidence in the estimate of effect.

Moderate quality: Further research is likely to have an important impact on our confidence in the estimate of effect and may change the estimate.

Low quality: Further research is very likely to have an important impact on our confidence in the estimate of effect and is likely to change the estimate.

Very low quality: We are very uncertain about the estimate.

${ }^{1}$ No risk factors for postoperative nausea and vomiting typically have control rates of $10 \%$; most studies in this systematic review had high risk patients with two or more risk factors for postoperative nausea and vomiting, therefore we assumed a risk of $40 \%$.

2 Total number of events is less than 300

3 Restlessness was more frequent after droperidol group than after acupuncture.

\section{DISCUSSION}

We have shown that P6 acupoint stimulation reduces the risk of PONV compared to sham treatment. P6 acupoint stimulation prevented postoperative nausea, vomiting, and need for antiemetic rescue by similar amounts (RR $0.71,95 \%$ CI 0.61 to 0.83 ; RR $0.70,95 \%$ CI 0.59 to 0.83 ; RR $0.69,95 \%$ CI 0.57 to 0.83 , respectively). Reduction of nausea, vomiting, and need for rescue antiemetics with P6 acupoint stimulation may reduce costs (such as antiemetic drug cost, length of stay in hospital) as well as improve quality of patient care. Although the relative risks for nausea and vomiting in subgroup analyses were not significant for control rates $\leq 20 \%$, but significant for $>20 \%$, the interactions were not significant; this suggests that the P6 acupoint stimulation effect was equal across subgroups. We did not find any interaction between the effect of P6 acupoint stimulation and age (children versus adults); type of P6 acupoint stimulation (invasive versus noninvasive); quality of sequence generation (adequate versus unclear or inadequate); quality of allocation concealment (adequate versus unclear or inadequate); blinding of outcome assessors (adequate versus unclear or inadequate); and selective reporting (free of versus unclear or 
not free of). Therefore, the reasons for the moderate heterogeneity among the trials are not clear. The moderate heterogeneity may be due to differences in the intensity of P6 acupoint stimulation, differences in underlying risk, trials of different sizes (Egger 1997), or the different timing of the outcome measures.

The quality of the included trials was variable. The allocation concealment technique was adequate in only four of 40 trials whilst the generation of allocation sequence was adequate in 17 trials. Whether outcome assessors, investigators, and patients were blinded to the intervention was difficult to assess in four trials because of insufficient information. It is difficult to provide good sham treatments. There may be subtle differences between inactive ReliefBand (Habib 2006; White 2002; Zarate 2001) and SeaBands with studs removed (Barsoum 1990; Duggal 1998; Ferrara-Love 1996; Klein 2004), when placed over the P6 acupoint. Despite possible differences in sham efficacy and intrinsic bias we analysed these sham treatments in one group. Selective reporting was the main bias found in 12 of 40 trials. Althoughmeta-analyses excluding unpublished outcomes are likely to over-estimate P6 acupoint stimulation effects, we did not find any interactions between the effect of P6 acupoint stimulation and level of selective reporting. Therefore, the impact of selective reporting on the point estimates in this Cochrane review are likely to be minimal.

Publication bias may be common for RCTs of traditional Chinese medicine (Tang 1999). The contour-enhanced funnel plots for nausea and vomiting showed no evidence of publication bias. In contrast to our last Cochrane review (Lee 2004), we did not use Egger's test (Egger 1997) for funnel plot asymmetry because it is problematic (Higgins 2008). The addition of another 10 studies examining P6 acupoint stimulation versus sham for postoperative nausea since our previous Cochrane review (Lee 2004) did not change the relative risk estimate. If publication bias and a country effect on the results were present, we would have expected the relative risk of nausea to be no longer significant after adjusting for country effect (Lee 2006). Thus, we are confident that publication bias is minimal in this review.

We did not undertake a dose-response relationship analysis for P6 acupoint stimulation time and intervention effect. Although 18 trials had sufficient data on the duration of P6 acupoint stimulation on outcomes at 24 hours after surgery, none of them randomized participants to one timing (for example 6 hours duration) or another (such as 24 hours duration).

Conclusions about differences in effect due to differences in dose are strongest if participants are randomized within a study to one dose or another and a consistent relationship is found across similar studies Higgins 2008). Also, many meta-regression analyses have low power to detect genuine relationships (Higgins 2008).

Comparing P6 acupoint stimulation to prophylactic antiemetic drugs, our previous Cochrane review (Lee 2004) showed a significant reduction in nausea (RR 0.70, 95\% CI 0.50 to 0.98) but not in vomiting (RR 0.92, 95\% CI 0.65 to 1.29). In this Cochrane review, after adding three small studies (< 100 participants each), we found no reliable evidence for differences in risk of postoperative nausea or vomiting after P6 acupoint stimulation compared to antiemetic drugs. For nausea, the RR was 0.82 (95\% CI 0.60 to 1.13 ). Interestingly, the method of sequence generation modified the P6 acupoint stimulation effect; unclear or inadequate sequence generation over-estimated the effect on nausea. For vomiting, the RR was 1.01 (95\% CI 0.77 to 1.31 ) with no significant risk of bias interactions. The wide confidence intervals around the point estimates for nausea and vomiting in this review suggest that we still have little knowledge about the effect size, and that further information is needed. 
Whether P6 acupoint stimulation is a useful modality within multimodal prophylaxis of PONV remains unclear. This Cochrane review identified only one trial (Schultz 2003) that compared a combination of an antiemetic medication and P6 acupoint stimulation versus sham, with imprecise results.

\section{AUTHORS' CONCLUSIONS}

\section{Implications for practice}

Patients with a very high baseline risk of postoperative nausea and vomiting are more likely to benefit from P6 acupoint stimulation (Table 1). No major side effects were associated with P6 acupoint stimulation. The risks of postoperative nausea and vomiting were similar after P6 acupoint stimulation and antiemetic drugs. P6 acupoint stimulation may be a suitable alternative or addition to antiemetic drugs for preventing postoperative nausea and vomiting.

\section{Implications for research}

Further research is unlikely to reverse the conclusion that P6 acupoint stimulation, versus sham, reduces the risk of PONV but it is likely to alter confidence in the effect, and possibly the point estimate. Further research should investigate whether the duration of P6 acupoint stimulation alters its effect on PONV. Future research should also examine whether combinations of interventions (that is multimodal prophylaxis) works better than each component alone and whether they interact. This updated systematic review found one small study (Schultz 2003) examining the combined effect of P6 acupoint stimulation administered with an antiemetic drug. Compared to sham, there was no significant reduction in PONV associated with the combined effect of P6 acupoint stimulation and droperidol (Schultz 2003). Patients receiving acu-stimulation and ondansetron in combination had a higher quality of recovery than those receiving ondansetron alone but there was no difference in the risk of PONV (White 2002). Therefore, the effect of combining P6 acupoint stimulation with an antiemetic medication is inconclusive and larger, rigorous trials are needed. More importantly, future trials should use adequate allocation concealment and include clinically relevant outcomes, such as quality of recovery, to draw meaningful conclusions.

\section{Supplementary Material}

Refer to Web version on PubMed Central for supplementary material.

\section{Acknowledgments}

We would like to thank John Carlise (content editor), Nathan Pace (statistical editor)Martin Tramèr, Christian Apfel, Scott Strassels, Milli Reddy (peer reviewers), Janet Wale (consumer), Karen Hovhannisyan and Jane Cracknell (CARG editorial office) for their help and editorial advice during the preparation of this updated review.

We would like to acknowledge Mary Done's contribution to the original published review (Lee 2004).

\section{SOURCES OF SUPPORT}

Internal sources

- Department of Anaesthesia and Intensive Care, The Chinese University of Hong Kong, Hong Kong.

External sources

- 2008 Cochrane Complementary Medicine Field Bursary, USA.

This work was partially funded by Grant Number R24 AT001293 from the National Center for Complementary and Alternative Medicine (NCCAM). The contents of this systematic review are solely the 
responsibility of the authors and do not necessarily represent the official views of the NCCAM or the National Institutes of Health.

\section{REFERENCES}

\section{References to studies included in this review}

Agarwal A, Pathak A, Gaur A. Acupressure wristbands do not prevent postoperative nausea and vomiting after urological endoscopic surgery. Canadian Journal of Anaesthesia. 2000; 47:319-324. [PUBMED: 10764175]. [PubMed: 10764175]

Agarwal A, Bose N, Gaur A, Singh U, Gupta MK, Singh D. Acupressure and ondansetron for postoperative nausea and vomiting after laparoscopic cholecystectomy. Canadian Journal of Anesthesia. 2002; 49:554-560. [PUBMED: 12067865]. [PubMed: 12067865]

Alkaissi A, Stalnert M, Kalman S. Effect and placebo effect of acupressure (P6) on nausea and vomiting after outpatient gynaecological surgery. Acta Anaesthesiologica Scandinavica. 1999; 43:270-274. [PUBMED: 10081532]. [PubMed: 10081532]

Alkaissi A, Evertsson K, Johnsson V, Ofenbartl L, Kalman S. P6 acupressure may relieve nausea and vomiting after gynecological surgery: an effectiveness study in 410 women. Canadian Journal of Anesthesia. 2002; 49:1034-1039. [PUBMED: 12477673]. [PubMed: 12477673]

Allen DL, Kitching AJ, Nagle C. P6 acupressure and nausea and vomiting after gynaecological surgery. Anaesthesia and Intensive Care. 1994; 22:691-693. [PUBMED: 7892973]. [PubMed: 7892973]

Amir SH, Bano S, Khan RM, Ahmed M, Zia F, Nasreen F. Electro-stimulation at P6 for prevention of PONV. Journal of Anaesthesiology Clinical Pharmacology. 2007; 23:383-386. [EMBASE: 2007618549].

Andrzejowski J, Woodward D. Semi-permanent acupuncture needles in the prevention of postoperative nausea and vomiting. Acupuncture in Medicine. 1996; 14:68-70. [EMBASE: 1997049450].

Arnberger M, Stadelmann K, Alischer P, Ponert R, Melber A, Greif R, Unibe MME. Monitoring of neuromuscular blockade at the P6 acupuncture point reduces the incidence of postoperative nausea and vomiting. Anesthesiology. 2007; 107:903-908. [PUBMED: 18043058]. [PubMed: 18043058]

Barsoum G, Perry EP, Fraser IA. Postoperative nausea is relieved by acupressure. Journal of the Royal Society of Medicine. 1990; 83:86-89. [PUBMED: 2181138]. [PubMed: 2181138]

Butkovic D, Toljan S, Matolic M, Kralik S, Radesic L. Comparison of laser acupuncture and metoclopramide in PONV prevention in children. Pediatric Anesthesia. 2005; 15:37-40. [PUBMED: 15649161]. [PubMed: 15649161]

Duggal KN, Douglas MJ, Peter EA, Merrick PM. Acupressure for intrathecal narcotic-induced nausea and vomiting after caesarean section. International Journal of Obstetric Anesthesia. 1998; 7:231236. [EMBASE: 1998371495]. [PubMed: 15321185]

Dundee JW, Chestnutt WN, Ghaly RG, Lynas AG. A traditional Chinese acupuncture: a potentially useful antiemetic? British Medical Journal. 1986; 293:583-584. [PUBMED: 3092933]. [PubMed: 3092933]

Dundee JW, Ghaly RG, Bill KM, Chestnutt WN, Fitzpatrick KTJ, Lynas AGA. Effect of stimulation of the P6 antiemetic point on postoperative nausea and vomiting. British Journal of Anaesthesia. 1989; 63:612-618. [PUBMED: 2605083]. [PubMed: 2605083]

Fassoulaki A, Papilas K, Sarantopoulos C, Zotou M. Transcutaneous electrical nerve stimulation reduces the incidence of vomiting after hysterectomy. Anesthesia and Analgesia. 1993; 76:10121014. [PUBMED: 8484499]. [PubMed: 8484499]

Ferrara-Love R, Sekeres L, Bircher NG. Nonpharmacological treatment of postoperative nausea. Journal of Perianesthesia Nursing. 1996; 11:378-383. [PUBMED: 9069860]. [PubMed: 9069860]

Gan TJ, Jiao KR, Zenn M, Georgiade G. A randomized controlled comparison of electro-acupoint stimulation or ondansetron versus placebo for the prevention of postoperative nausea and vomiting. Anesthesia and Analgesia. 2004; 99:1070-1075. [PUBMED: 15385352]. [PubMed: 15385352] 
Gieron C, Wieland B, von der Laage D, Tolksdorf W. Acupressure in the prophylaxis of postoperative nausea and vomiting. Anaesthesist. 1993; 42:221-226. [PUBMED: 8488993]. [PubMed: 8488993]

Habib AS, Itchon-Ramos N, Phillips-Bute BG, Gan TJ. the Duke Women's Anesthesia (DWA) Research Group. Transcutaneous acupoint electrical stimulation with the ReliefBand for the prevention of nausea and vomiting during and after Cesarean delivery under spinal anesthesia. Anesthesia and Analgesia. 2006; 102:581-584. [PUBMED: 16428565]. [PubMed: 16428565]

Harmon D, Gardiner J, Harrison R, Kelly A. Acupressure and the prevention of nausea and vomiting after laparoscopy. British Journal of Anaesthesia. 1999; 82:387-390. [PUBMED: 10434821]. [PubMed: 10434821]

Harmon D, Ryan M, Kelly A, Bowen M. Acupressure and prevention of nausea and vomiting during and after spinal anaesthesia for Caesarean section. British Journal of Anaesthesia. 2000; 84:463467. [PUBMED: 10823097]. [PubMed: 10823097]

Ho RT, Jawan B, Fung ST, Cheung HK, Lee JH. Electro-acupuncture and postoperative emesis. Anaesthesia. 1989; 45:327-329. [PUBMED: 2140030]. [PubMed: 2140030]

Ho CM, Hseu SS, Tsai SK, Lee TY. Effect of P6 acupressure on prevention of nausea and vomiting after epidural morphine for post-Cesarean section pain relief. Acta Anaesthesiologica Scandinavica. 1996; 40:372-375. [PUBMED: 8721471]. [PubMed: 8721471]

Klein AA, Djaiani G, Karski J, Carroll J, Karkouti K, McCluskey S, Poonawala H, Shayan C, Fedorko L, Cheng D. Acupressure wristbands for the prevention of postoperative nausea and vomiting in adults undergoing cardiac surgery. Journal of Cardiothoracic and Vascular Anesthesia. 2004; 18:68-71. [PUBMED: 14973803]. [PubMed: 14973803]

Lewis IH, Pryn SJ, Reynolds PI, Pandit UA, Wilton NCT. Effect of P6 acupressure on postoperative vomiting in children undergoing outpatient strabismus correction. British Journal of Anaesthesia. 1991; 67:73-78. [PUBMED: 1859764]. [PubMed: 1859764]

Liu YY, Duan SE, Cai MX, Zou P, LY, Li YL. Evaluation of transcutaneous electroacupoint stimulation with the train-of-four mode for preventing nausea and vomiting after laparoscopic cholecystectomy. Chinese Journal of Integrative Medicine. 2008; 14:94-97. [PUBMED: 18679598]. [PubMed: 18679598]

Misra MN, Pullani AJ, Mohamed ZU. Prevention of PONV by acustimulation with capsicum plaster is comparable to ondansetron after middle ear surgery. Canadian Journal of Anesthesia. 2005; 52:485-489. [PUBMED: 15872126]. [PubMed: 15872126]

Rusy LM, Hoffman GM, Weisman SJ. Electroacupuncture prophylaxis of postoperative nausea and vomiting following pediatric tonsillectomy with or without adenoidectomy. Anesthesiology. 2002; 96:300-305. [PUBMED: 11818760]. [PubMed: 11818760]

Samad K, Afshan G, Kamal R. Effect of acupressure on postoperative nausea and vomiting in laparoscopic cholecystectomy. Journal of the Pakistan Medical Association. 2003; 53:68-72. [PUBMED: 12705488]. [PubMed: 12705488]

Schlager A, Offer T, Baldissera I. Laser stimulation of acupuncture point P6 reduces postoperative vomiting in children undergoing strabismus surgery. British Journal of Anaesthesia. 1998; 81:529532. [PUBMED: 9924226]. [PubMed: 9924226]

Schultz AA, Andrews AL, Goran SF, Mathew T, Sturdevant N. Comparison of acupressure bands and droperidol for reducing post-operative nausea and vomiting in gynecologic surgery patients. Applied Nursing Research. 2003; 4:256-265. [PUBMED: 14608559]. [PubMed: 14608559]

Sharma S, Goswami U. Evaluation of acupuncture for anti-emetic prophylaxis. Journal of Anaesthesiology Clinical Pharmacology. 2007; 23:401-404. [EMBASE: 2007618554].

Shenkman Z, Holzman RS, Kim C, Ferrari LR, DiCanzio J, Highfield ES, et al. Acupressureacupuncture antiemetic prophylaxis in children undergoing tonsillectomy. Anesthesiology. 1999; 90:1311-1316. [PUBMED: 10319779]. [PubMed: 10319779]

Streitberger K, Diefenbacher M, Bauer A, Conradi R, Bardenheuer H, Martin E, Schneider A, Unnebrink K. Acupuncture compared to placebo-acupuncture for postoperative nausea and vomiting prophylaxis: a randomised placebo-controlled patient and observer blind trial. Anaesthesia. 2004; 59:142-149. [PUBMED: 14725517]. [PubMed: 14725517]

Tavlan A, Baltaci B, Alptekin A, Ceyhan A, Unal N. A comparison of the effect of single dose ondansetron and P6 (neiguan) acupuncture point on postoperative nausea and vomiting for 
gynaecological laparoscopy. European Journal of Anaesthesiology. 1996; Vol. 13:164. [: CN-00258411].

Turgut S, Ozalp G, Dikmen S, Savil S, Tuncel G, Kadiogullari N. Acupressure for postoperative nausea and vomiting in gynaecological patients receiving patient-controlled analgesia. European Journal of Anaesthesiology. 2007; 24:87-91. [PUBMED: 16895618]. [PubMed: 16895618]

Wang SM, Kain ZN. P6 acupoint injections are as effective as droperidol in controlling early postoperative nausea and vomiting in children. Anesthesiology. 2002; 97:359-366. [PUBMED: 12151925]. [PubMed: 12151925]

White PF, Issioui T, Hu J, Jones SB, Coleman JE, Waddle JP, et al. Comparative efficacy of acustimulation (ReliefBand) versus ondansetron (Zofran) in combination with droperidol for preventing nausea and vomiting. Anesthesiology. 2002; 97:1075-1081. [PUBMED: 12411789]. [PubMed: 12411789]

Yang LC, Jawan B, Chen CN, Ho RT, Chang KA, Lee JH. Comparison of P6 acupoint injection with $50 \%$ glucose in water and intravenous droperidol for prevention of vomiting after gynecological laparoscopy. Acta Anaesthesiologica Scandinavica. 1993; 37:192-194. [PUBMED: 8447210]. [PubMed: 8447210]

Yentis SM, Bissonnette B. Ineffectiveness of acupuncture and droperidol in preventing vomiting following strabismus repair in children. Canadian Journal of Anaesthesia. 1992; 39:151-154. [PUBMED: 1544195]. [PubMed: 1544195]

Zarate E, Mingus M, White PF, Chiu JW, Scuderi P, Loskota W, et al. The use of transcutaneous acupoint electrical stimulation for preventing nausea and vomiting after laparoscopic surgery. Anesthesia and Analgesia. 2001; 92:629-635. [PUBMED: 11226090]. [PubMed: 11226090]

\section{References to studies excluded from this review}

Agarwal A, Dhiraaj S, Tandon M, Singh PK, Singh U, Pawar S. Evaluation of capsaicin ointment at the Korean hand acupressure point K-D2 for prevention of postoperative nausea and vomiting. Anaesthesia. 2005; 60:1185-1188. [PUBMED: 16288616]. [PubMed: 16288616]

Al-Sadi M, Newman B, Julious SA. Acupuncture in the prevention of postoperative nausea and vomiting. Anaesthesia. 1997; 52:658-661. [PUBMED: 9244025]. [PubMed: 9244025]

Alkaissi A, Ledin T, Odkvist LM, Kalman S. P6 acupressure increases tolerance to nauseogenic motion stimulation in women at high risk for PONV. Canadian Journal of Anesthesia. 2005; 52:703-709. [PUBMED: 16103382]. [PubMed: 16103382]

Cekmen N, Salman B, Keles Z, Aslan M, Akcabay M. Transcutaneous electrical nerve stimulation in the prevention of postoperative nausea and vomiting after elective laparoscopic cholecystectomy. Journal of Clinical Anesthesia. 2007; 19:49-52. [PUBMED: 17321927]. [PubMed: 17321927]

Chen HM, Chang FY, Hsu CT. Effect of acupressure on nausea, vomiting, anxiety and pain among post-cesarean section women in Taiwan. Kaohsiung Journal of Medical Sciences. 2005; 21:341350. [PUBMED: 16158876]. [PubMed: 16158876]

Coloma M, White PF, Ogunnaike BO, Markowitz SD, Brown PM, Lee AQ, et al. Comparison of acustimulation and ondansetron for the treatment of established postoperative nausea and vomiting. Anesthesiology. 2002; 97:1387-1392. [PUBMED: 12459663]. [PubMed: 12459663]

Dundee JW, Milligan KR, McKay AC. Influence of intraoperative acupuncture and droperidol on postoperative emesis. British Journal of Anaesthesia. 1988; 61:116P-117P.

Dundee JW, Ghaly G. Local anesthesia blocks the antiemetic action of P6 acupuncture. Clinical Pharmacology and Therapeutics. 1991; 50:78-80. [PUBMED: 1855355]. [PubMed: 1855355]

Fan CF, Tanhui E, Joshi S, Trivedi S, Hong Y, Shevde K. Acupressure treatment for prevention of postoperative nausea and vomiting. Anesthesia and Analgesia. 1997; 84:821-825. [PUBMED: 9085965]. [PubMed: 9085965]

Fry ENS. Acupressure and postoperative vomiting. Anaesthesia. 1986; 41:661-662. [PUBMED: 3728942]. [PubMed: 3728942]

Ho CM, Tsai HJ, Chan KH, Tsai SK. P6 acupressure does not prevent emesis during spinal anesthesia for Cesarean delivery. Anesthesia and Analgesia. 2006; 102:900-903. [PUBMED: 16492848]. [PubMed: 16492848] 
Kabalak AA, Akcay M, Akcay F, Gogus N. Transcutaneous electrical acupoint stimulation versus ondansetron in the prevention of postoperative vomiting following pediatric tonsillectomy. Journal of Alternative and Complementary Medicine. 2005; 11:407-413. [PUBMED: 15992223].

Khan RM, Maroof M, Hakim S, Jain D, Ashraf M. Intraoperative stimulation of the P6 point controls postoperative nausea and vomiting following laparoscopic surgery. Canadian Journal of Anesthesia. 2004; 7:740-741. [PUBMED: 15310647]. [PubMed: 15310647]

Kim KS, Koo MS, Jeon JW, Park HS, Seung IS. Capsicum plaster at the Korean hand acupuncture point reduces postoperative nausea and vomiting after abdominal hysterectomy. Anesthesia and Analgesia. 2002; 95:1103-1107. [PUBMED: 12351304]. [PubMed: 12351304]

McMillan CM. Transcutaneous electrical stimulation of Neiguan antiemetic acupuncture point in controlling sickness following opioid analgesia in major orthopaedic surgery. Physiotherapy. 1994; 80:5-9.

Ming JL, Kuo BI, Lin JG, Lin LC. The efficacy of acupressure to prevent nausea and vomiting in postoperative patients. Journal of Advanced Nursing. 2002; 39:343-351. [PUBMED: 12139646]. [PubMed: 12139646]

Phillips K, Gill L. The use of simple acupressure bands reduces post-operative nausea. Complementary Therapies in Medicine. 1994; 2:158-160.

Schneider A, Lowe B, Streitberger K. Perception of bodily sensation as a predictor of treatment response to acupuncture for postoperative nausea and vomiting prophylaxis. Journal of Alternative and Complementary Medicine. 2005; 11:119-125. [PUBMED: 15750370].

Schwager KL, Baines DB, Meyer RJ. Acupuncture and postoperative vomiting in day-stay paediatric patients. Anaesthesia and Intensive Care. 1996; 24:674-677. [PUBMED: 8971315]. [PubMed: 8971315]

Shyr MH, Hsu JC, Wu YW, Hui YL, Tan PPC. P6 acupoint injection reduced postoperative nausea and vomiting. Ma Tsui Hsueh Tsa Chi Anaesthesiologica Sinica. 1990; 28:357-360. [PUBMED: 2277579].

Somri M, Vaida SJ, Sabo E, Yassain G, Gankin I, Gaitini LA. Acupuncture versus ondansetron in the prevention of postoperative vomiting. Anaesthesia. 2001; 56:927-932. [PUBMED: 11576093]. [PubMed: 11576093]

Stein DJ, Birnbach DJ, Danzer BI, Kuroda MM, Grunebaum A, Thys DM. Acupressure versus intravenous metoclopramide to prevent nausea and vomiting during spinal anesthesia for cesarean section. Anesthesia and Analgesia. 1997; 84:342-345. [PUBMED: 9024025]. [PubMed: 9024025]

Weightman WM, Zacharias M, Herbison P. Traditional Chinese acupuncture as an antiemetic. British Medical Journal. 1987; 295:1379-1380. [PUBMED: 3121022]. [PubMed: 3121022]

White PF, Hamza MA, Recart A, Coleman JE, Macaluso AR, Cox L, Jaffer O, Song D, Rohrich R. Optimal timing of acustimulation for antiemetic prophylaxis as an adjunct to ondansetron in patients undergoing plastic surgery. Anesthesia and Analgesia 2005. 2005; 100:367-372. [PUBMED: 15673859].

Windle PE, Borromeo A, Robles H, Ilacio-Uy V. The effects of acupressure on the incidence of postoperative nausea and vomiting in postsurgical patients. Journal of Perianesthesia Nursing. 2001; 16:158-162. [PUBMED: 11395836]. [PubMed: 11395836]

Yentis SM, Bissonnette B. P6 acupuncture and postoperative vomiting after tonsillectomy in children. British Journal of Anaesthesia. 1991; 67:779-780. [PUBMED: 1768550]. [PubMed: 1768550]

Yentis SM, Vashisht S. The effect of timing of P6 acupuncture on post-operative vomiting following major gynaecological surgery. Acupuncture in Medicine. 1998; 16:10-13.

\section{Additional references}

Altman DG. Confidence intervals for the number needed to treat. BMJ. 1998; 317:1309-1312.

[PUBMED: 9804726]. [PubMed: 9804726]

Altman DG, Bland JM. Interaction revisited: the difference between two estimates. BMJ. 2003; 326:219. [PUBMED: 12543843]. [PubMed: 12543843] 
Carlisle JB, Stevenson CA. Drugs for preventing postoperative nausea and vomiting. Cochrane Database of Systematic Reviews. 2006; (Issue 3) CD004125. [DOI: 10.1002/14651858.CD004125.pub2; PUBMED: 16856030].

Duval S, Tweedie R. Trim and fill: a simple funnel-plot-based method of testing and adjusting for publication bias in meta-analysis. Biometrics. 2000; 56:455-463. [PUBMED: 10877304]. [PubMed: 10877304]

Egger M, Davey Smith G, Schneider M, Minder CE. Bias in meta-analysis detected by a simple, graphical test. BMJ. 1997; 315:629-634. [PUBMED: 9310563]. [PubMed: 9310563]

Gan TJ, Meyer T, Apfel CC, Chung F, Davis PJ, Habib AS, et al. Society for ambulatory anesthesia: guidelines for the management of postoperative nausea and vomiting. Anesthesia and Analgesia. 2007; 105:1615-1628. [PUBMED: 18042859]. [PubMed: 18042859]

Gin T. Recent advances in the understanding and management of postoperative nausea and vomiting. Annals of Academic Medicine of Singapore. 1994; 23 Suppl 6:114-119. [PUBMED: 7710220].

Higgins, JPT.; Green, S. Cochrane Handbook for Systematic Reviews of Interventions Version 5.0.0. The Cochrane Collaboration; Cochrane Handbook for Systematic Reviews of Interventions. updated February 2008. Available from www.cochrane-handbook.org

Lee A, Copas JB, Henmi M, Gin T, Chung RCK. Publication bias affected the estimate of postoperative nausea in an acupoint stimulation systematic review. Journal of Clinical Epidemiology. 2006; 59:980-983. [PUBMED: 16895822]. [PubMed: 16895822]

Mann, F. Textbook of acupuncture. London: William Heinemann Medical Books; 1987.

McAuley L, Pham B, Tugwell P, Moher D. Does the inclusion of grey literature influence estimates of intervention effectiveness reported in meta-analyses? Lancet. 2000; 356:1228-1231. [PUBMED: 11072941]. [PubMed: 11072941]

Mosteller F, Colditz GA. Understanding research synthesis (meta-analysis). Annual Review of Public Health. 1996; 17:1-23. [PUBMED: 8724213].

National Institutes of Health. Consensus Statement Online. Vol. Vol. 15. National Institutes of Health; 1997 Nov 3-5. Acupuncture; p. 1-34.

Peters JL, Sutton AJ, Jones DR, Abrams KR, Rushton L. Contour-enhanced meta-analysis funnel plots help distinguish publication bias from other causes of asymmetry. Journal of Clinical Epidemiology. 2008; 61:991-996. [PUBMED: 18538991]. [PubMed: 18538991]

Petitti, DB. Meta-analysis, decision analysis and cost-effectiveness analysis: methods for quantitative synthesis in medicine. New York: Oxford University Press; 1994.

Rusy LM, Hoffman GM, Weisman SJ. Anesthesiology. 2002; 97:1039. [PUBMED: 12357192]. [PubMed: 12357193]

Sadhasivam S, Saxena A, Kathirvel S, Kannan TR, Trikha A, Mohan V. The safety and efficacy of prophylactic ondansetron in patients undergoing modified radical mastectomy. Anesthesia and Analgesia. 1999; 89:1340-1345. [PUBMED: 10589605]. [PubMed: 10589605]

Smeeth L, Haines A, Ebrahim S. Numbers needed to treat derived from meta-analyses - sometimes informative, usually misleading. BMJ. 1999; 318:1548-1551. [PUBMED: 10356018]. [PubMed: 10356018]

Tang JL, Zhan SY, Ernst E. Review of randomised controlled trials of traditional Chinese medicine. BMJ. 1999; 319:160-162. [PUBMED: 10406751]. [PubMed: 10406751]

Vickers AJ. Can acupuncture have specific effects on health? A systematic review of acupuncture antiemesis trials. Journal of the Royal Society of Medicine. 1996; 89:303-311. [PUBMED: 8758186]. [PubMed: 8758186]

Watcha MF, White PF. Postoperative nausea and vomiting: its etiology, treatment and prevention. Anesthesiology. 1992; 77:162-184. [PUBMED: 1609990]. [PubMed: 1609990]

White PF, Watcha MF. Has the use of meta-analysis enhanced our understanding of therapies for postoperative nausea and vomiting? Anesthesia and Analgesia. 1999; 88:1200-1202. [PUBMED: 10357318]. [PubMed: 10357318] 


\section{References to other published versions of this review}

Lee A, Done ML. The use of nonpharmacologic techniques to prevent postoperative nausea and vomiting: a meta-analysis. Anesthesia and Analgesia. 1999; 88:1362-1369. [PUBMED: 10357346]. [PubMed: 10357346]

Lee A, Done ML. Stimulation of the wrist acupuncture point P6 for preventing postoperative nausea and vomiting. Cochrane Database of Systematic Reviews. 2004; (Issue 3) CD 003281. [DOI: 10.1002/14651858.CD003281.pub2; PUBMED: 15266478]. * Indicates the major publication for the study

\section{Appendix 1}

\section{Search strategy for CENTRAL, The Cochrane Library}

\# $\quad 1 \mathrm{MeSH}$ descriptor postoperative complications explode all trees

\# $\quad 2 \mathrm{MeSH}$ descriptor Postoperative Nausea and Vomiting explode all trees

\# $\quad 3 \mathrm{MeSH}$ descriptor nausea explode all trees

\# $\quad 4 \mathrm{MeSH}$ descriptor vomiting explode all trees

\# $\quad$ 5(nausea in All Text or vomiting in All Text)

\# $6(\# 1$ or \#2 or \#3 or \#4 or \#5)

\# $\quad$ 7MeSH descriptor acupuncture explode all trees

\# $\quad 8 \mathrm{MeSH}$ descriptor acupuncture therapy explode all trees

\# $\quad 9 \mathrm{MeSH}$ descriptor acupuncture points explode all trees

\# $\quad 10 \mathrm{MeSH}$ descriptor acupressure explode all trees

\# $\quad 11 \mathrm{MeSH}$ descriptor Transcutaneous Electric Nerve Stimulation explode all trees

\# $\quad 12 \mathrm{MeSH}$ descriptor electroacupuncture explode all trees

\# 13(electroacupuncture in All Text or electro-acupuncture in All Text)

\# 14acupressure in All Text

\# 15acupunct* in All Text

\# $\quad$ 16(nerve in All Text near/6 stimulat* in All Text)

$\# \quad 17(\# 7$ or \#8 or \#9 or \#10 or \#11 or \#12 or \#13 or \#14 or \#15 or \#16) \#18(\#6 and \#17)

\section{Appendix 2}

\section{Search strategy for SilverPlatter MEDLINE (WebSPIRS)}

\# $\quad 1$ explode Postoperative Complications / all subheadings

\# $\quad 2$ explode Postoperative Nausea / all subheadings and Vomiting

\# 3 explode nausea / all subheadings

\# 4 explode vomiting/ all subheadings\#5 nausea or vomiting or emesis

\# $6 \# 1$ or \#2 or \#3 or \#4 or \#5

\# $\quad 7$ explode acupuncture / all subheadings 


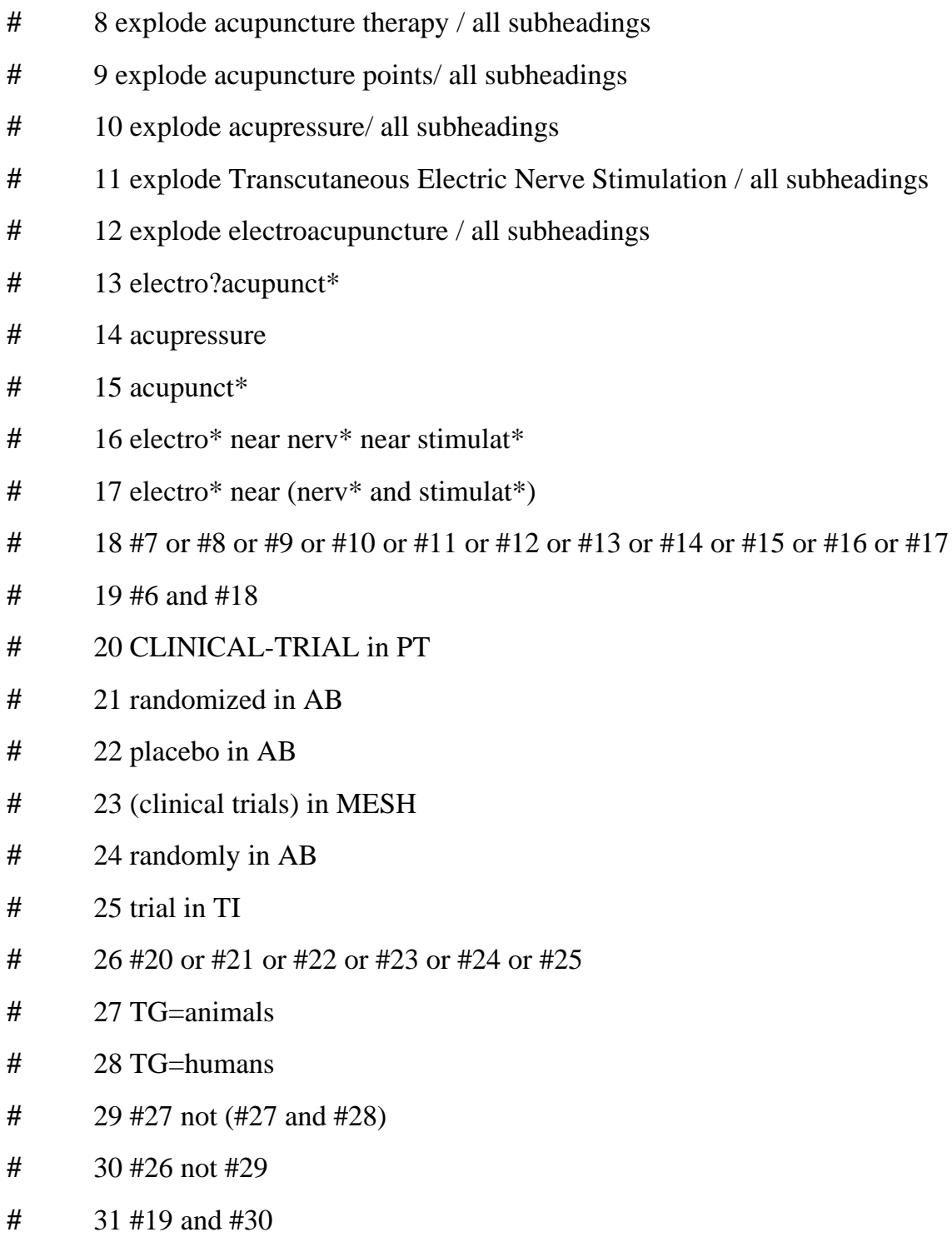

\section{Appendix 3}

\section{Search strategy for SilvePlatter EMBASE (WebSPIRS)}

\# 1 explode postoperative complication / all subheadings

\# $\quad 2$ explode postoperative nausea / all subheadings

\# 3 explode postoperative nausea / all subheadings and vomiting

\# 4 explode postoperative vomiting / all subheadings

\# 5 explode nausea / all subheadings

\# 6 explode vomiting / all subheadings

\# $\quad 7$ explode nausea / all subheadings and vomiting

\# 8 nausea or vomiting or emesis 


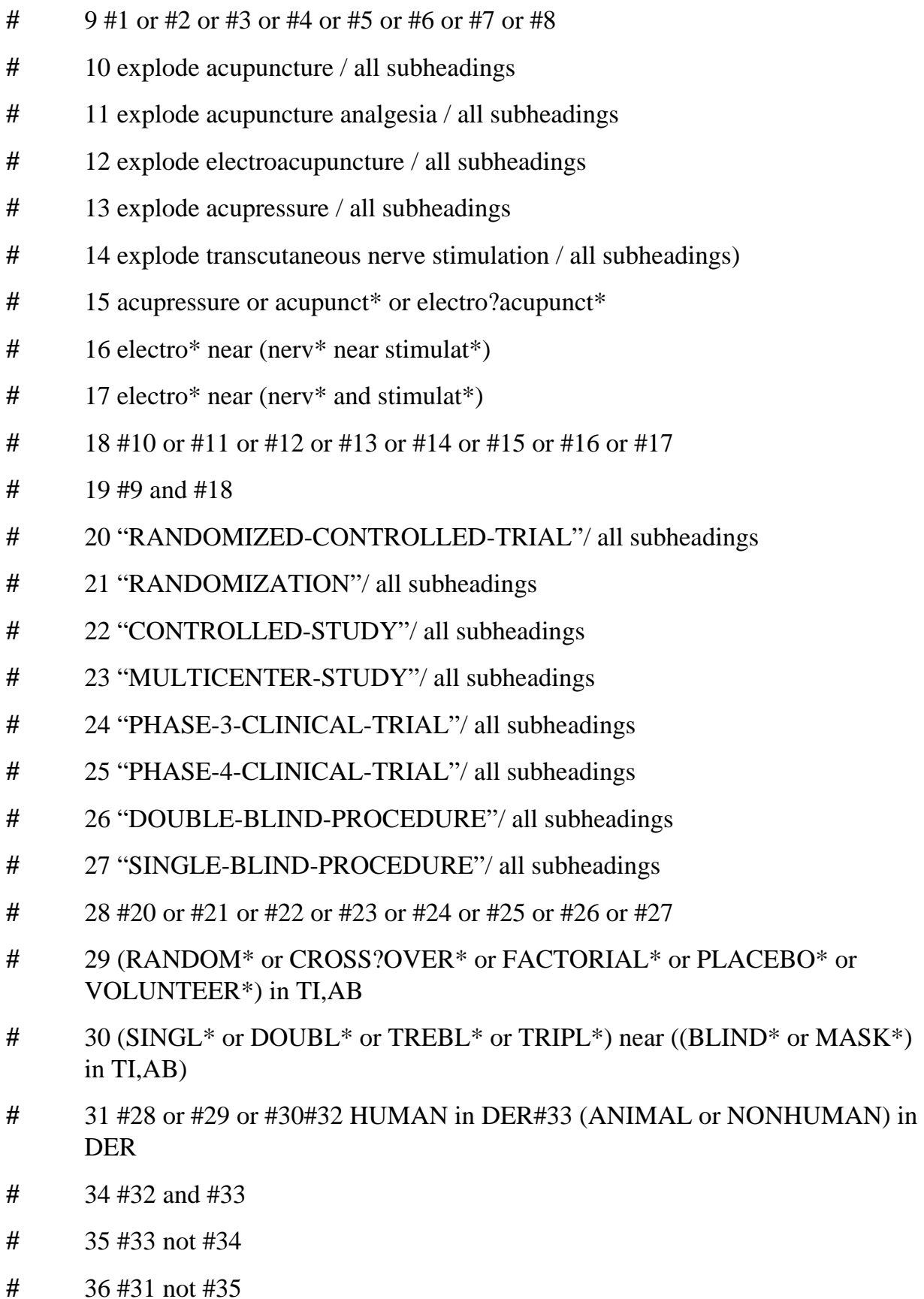

\title{
Appendix 4
}

\section{Search strategy for ISI Web of Science}

\author{
\# $\quad$ 1.TS=pos\$toperative complication* \\ \# 2.TS=nausea OR TS=vomiting OR TS=emesis \\ \# 3. \#2 OR \#1 \\ \# 4.TS=acupunct* OR TS=electro $\$$ acupunct* or TS=acupressure
}




\begin{tabular}{|c|c|}
\hline \# & 5.TS $=($ electro $*$ OR transcutaneous $)$ AME TS $=($ nerv* AND stimulat $*)$ \\
\hline \# & 6.\#5 OR \#4 \\
\hline \# & $\begin{array}{l}\text { 7.TS }=(\text { random* or clinical or control* or multi } \$ \text { cent } *) \text { SAME TS }=(\text { trial } * \text { or } \\
\left.\text { stud }^{*}\right)\end{array}$ \\
\hline \# & $\begin{array}{l}\text { 8.TS }=\left(\operatorname{singl} * \text { or doubl } * \text { or trebl* or tripl }{ }^{*}\right) \text { SAME TS }=\left(\text { blind }^{*} \text { or mask } * \text { or }\right. \\
\left.\text { method }^{*}\right)\end{array}$ \\
\hline \# & $\begin{array}{l}\text { 9.TS }=(\text { random* or allocat* or compar* or factorial } * \text { or follow } \$ \text { up or placebo* or } \\
\text { prospective }\end{array}$ \\
\hline \# & 10.\#9 OR \#8 OR \#7 \\
\hline \# & 11. \#10 AND \#6 AND \#3 \\
\hline
\end{tabular}




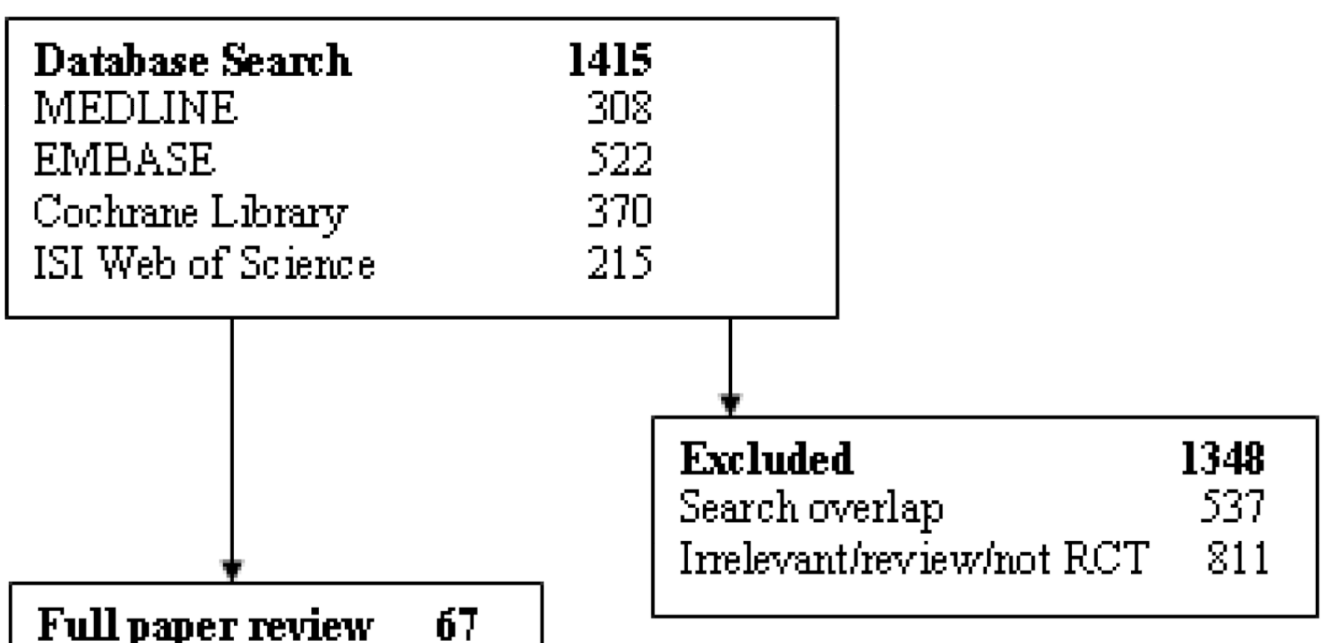

\section{Excluded}

Vot RCT

Fatients not relevart

Interventions not relevart

\section{Included}

P'6 acupoint stirnulation $\mathrm{W}$ sharr

\section{0 trials}

P6 acupoint stirnulation $w$ s antiernetics

34

14

Wurber of trials by outcome

Postoperative nausea

31

Fostoperative vorniting

39

Fescue artiernetic

Bdverse events

27

Figure 1.

Searching results 
Adequate sequence generation? Allocation concealment?

Incomplete outcome data addresed?

Free of selective reporting?

Free of other bias?

Blinding of patients

Blinding of healthcare providers

Blinding of outcome assessor
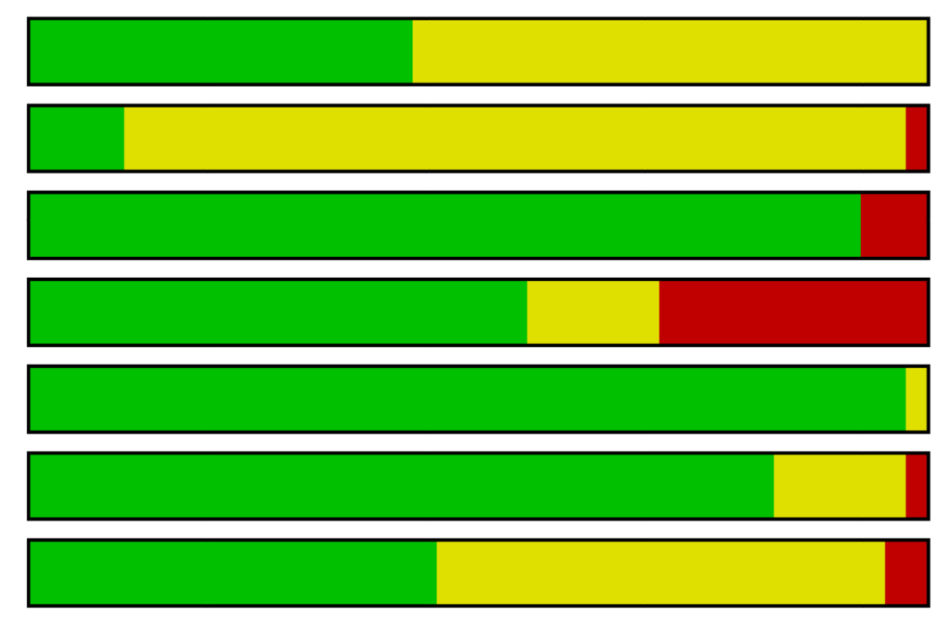

Bor outcome assessor

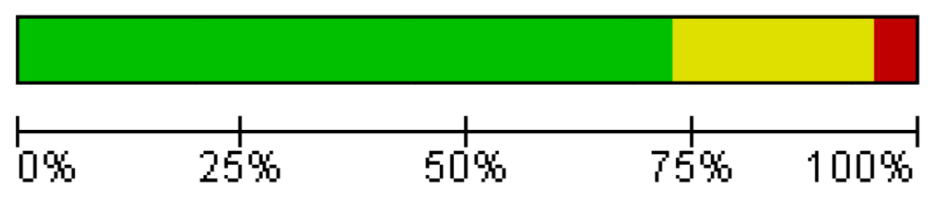

\begin{tabular}{|ll|}
\hline Yes (low risk of bias) $\quad \square$ Unclear \\
\hline
\end{tabular}

Figure 2.

Methodological quality graph: review authors' judgements about each methodological quality item presented as percentages across all included studies. 


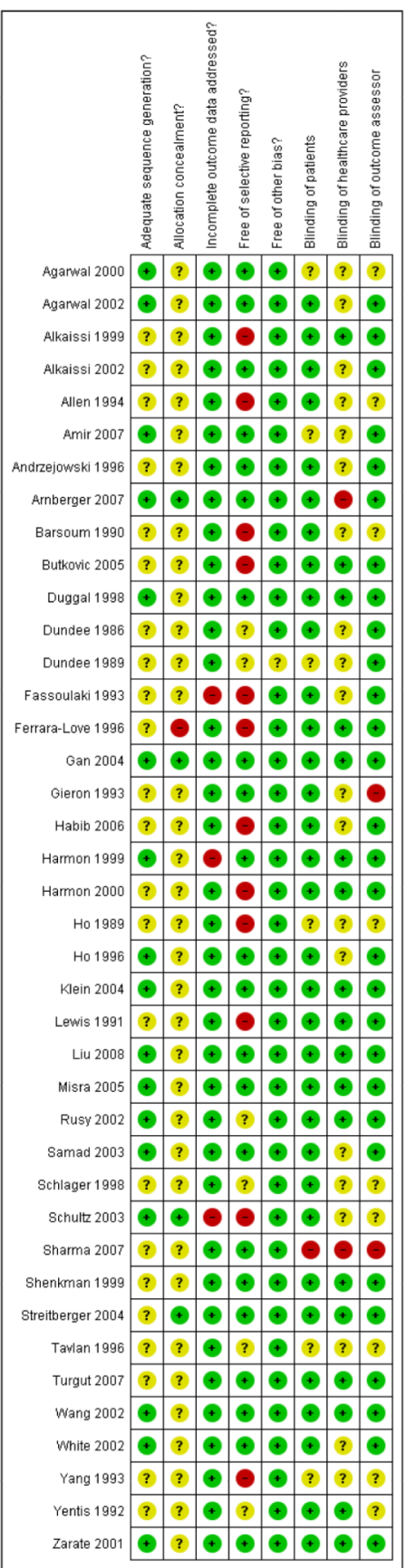

Figure 3.

Methodological quality summary: review authors' judgements about each methodological quality item for each included study. 


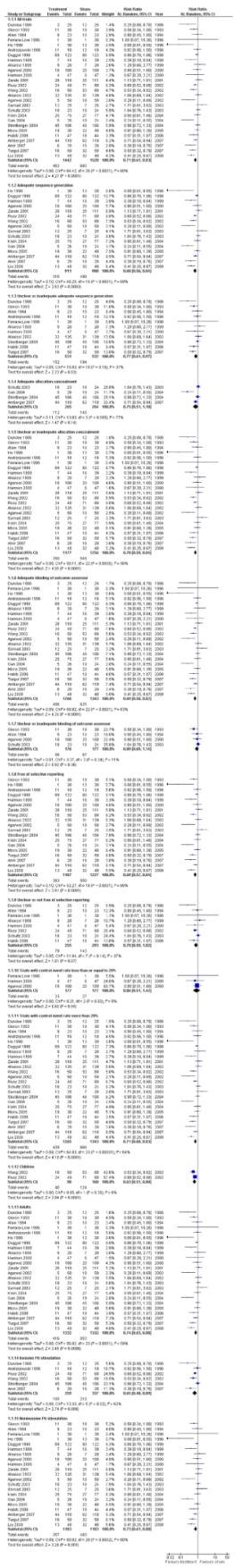

Figure 4.

Forest plot of comparison: 1 Acupoint P6 stimulation versus sham, outcome: 1.1 Nausea. 


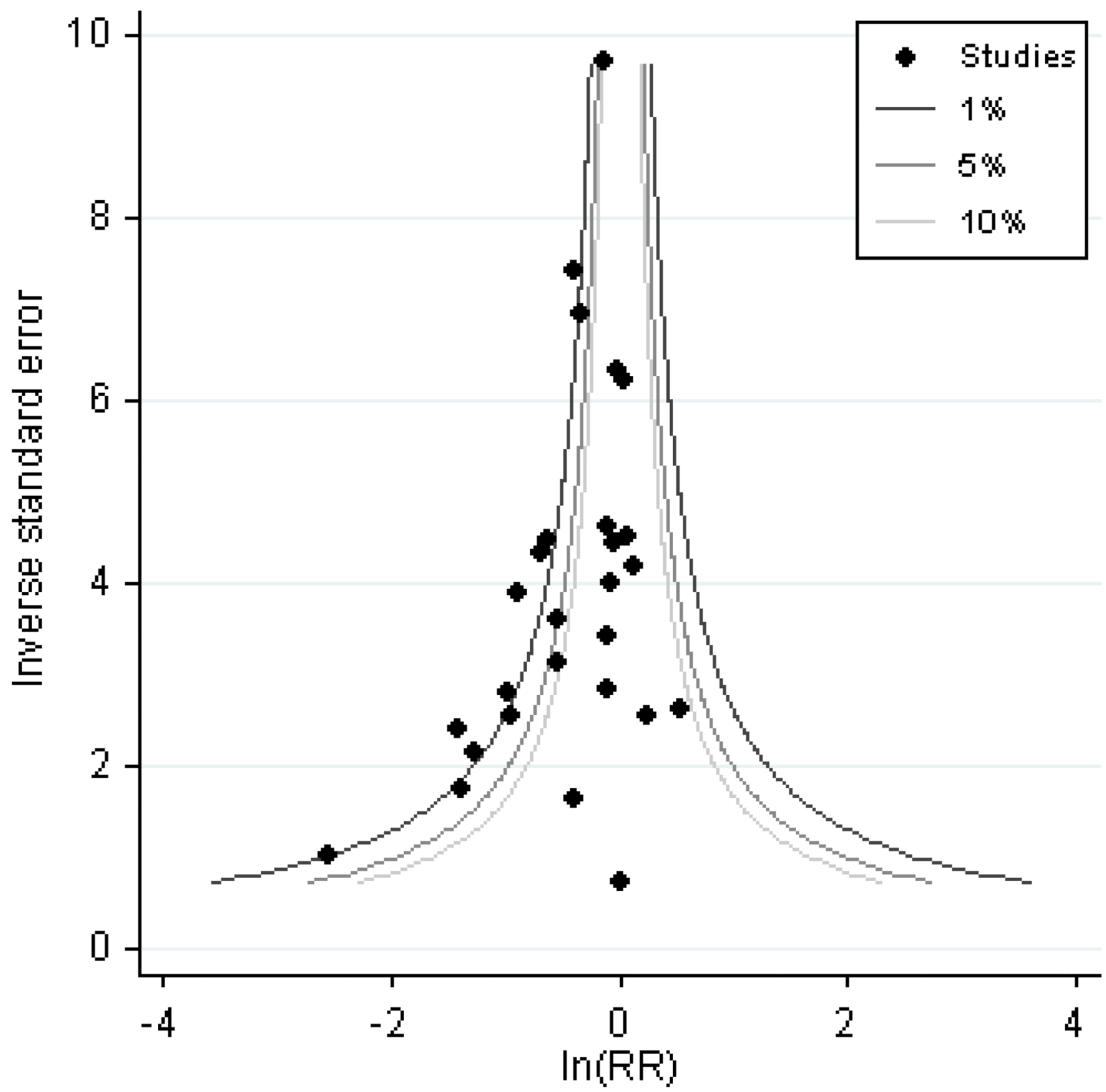

Figure 5.

Contour-enhanced funnel plot of comparison: 1 Acupoint P6 stimulation versus sham, outcome: 1.1 Nausea. Contour lines are at $1 \%, 5 \%$ and $10 \%$ levels of statistical significance. 


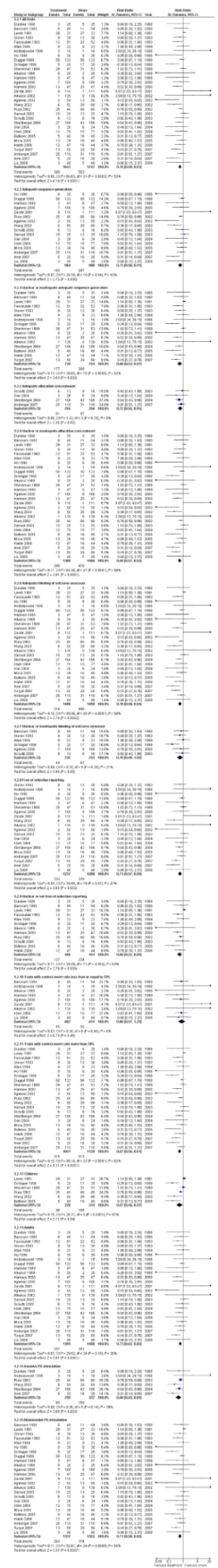

Figure 6.

Forest plot of comparison: 1 Acupoint P6 stimulation versus sham, outcome: 1.2 Vomiting. 


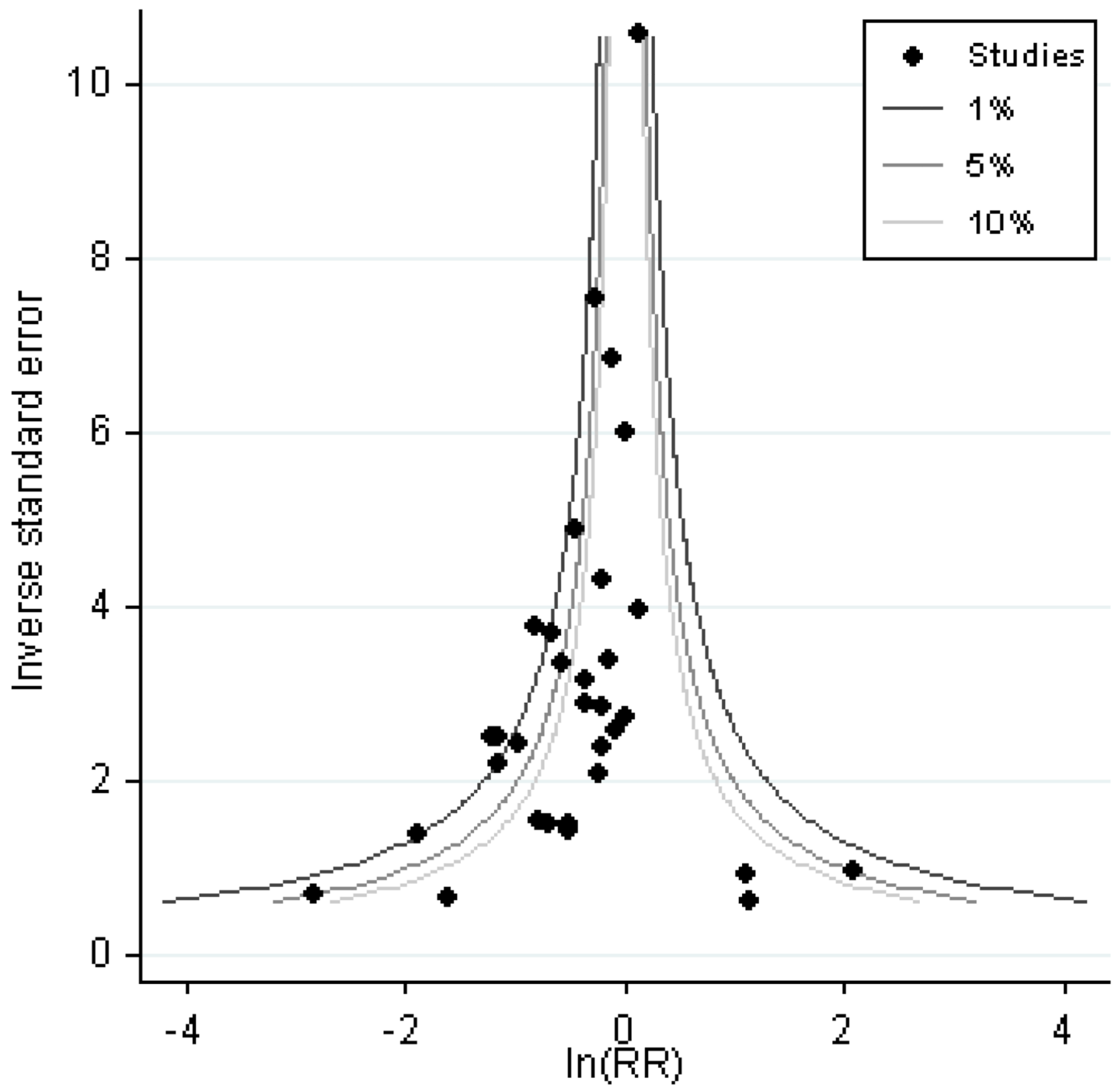

Figure 7.

Contour-enhanced funnel plot of comparison: 1 Acupoint P6 stimulation versus sham, outcome: 1.2 Vomiting. Contour lines are at $1 \%, 5 \%$ and $10 \%$ levels of statistical significance. 


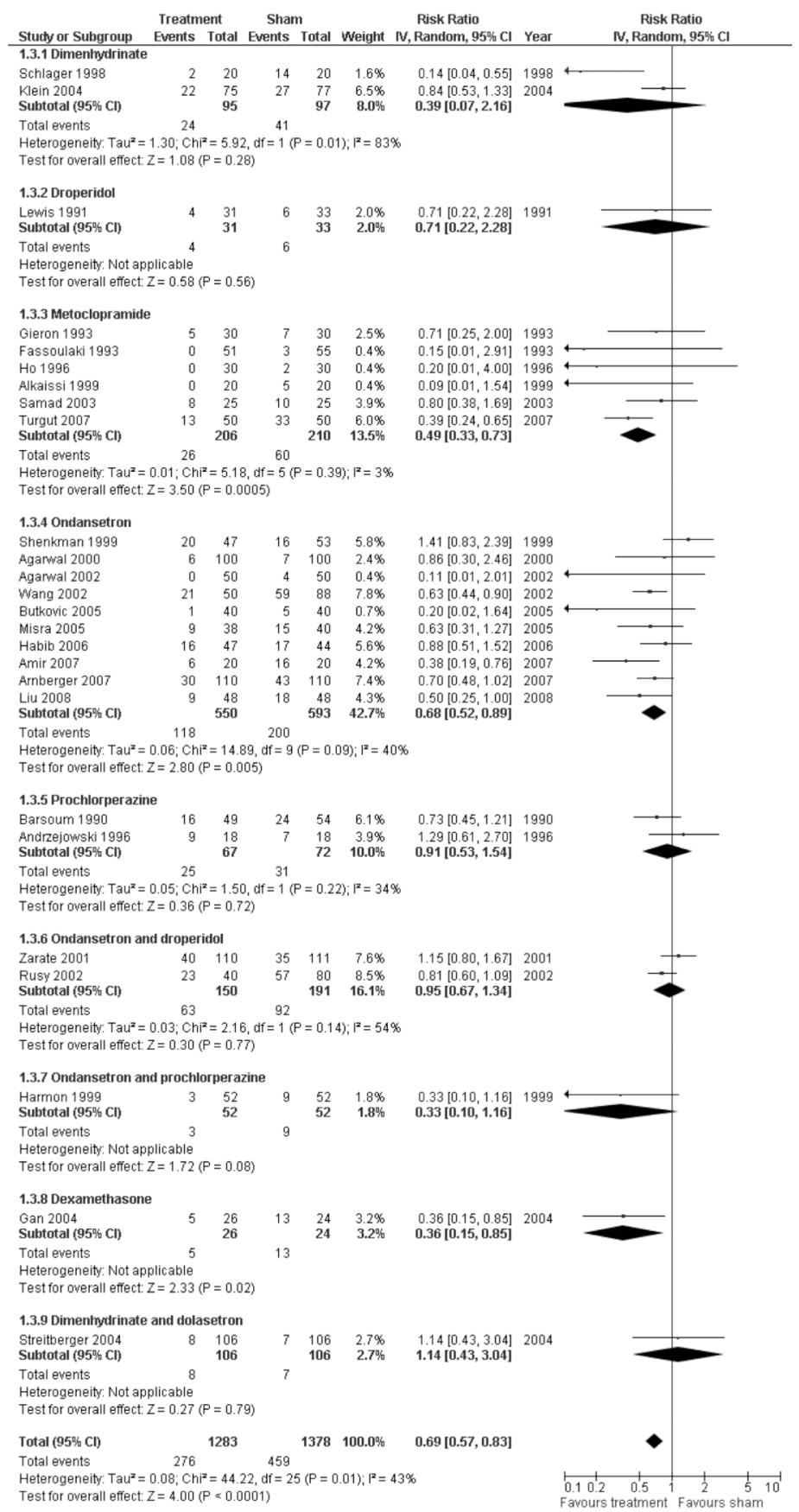

Figure 8.

Forest plot of comparison: 1 Acupoint P6 stimulation versus sham, outcome: 1.3 Rescue antiemetics. 


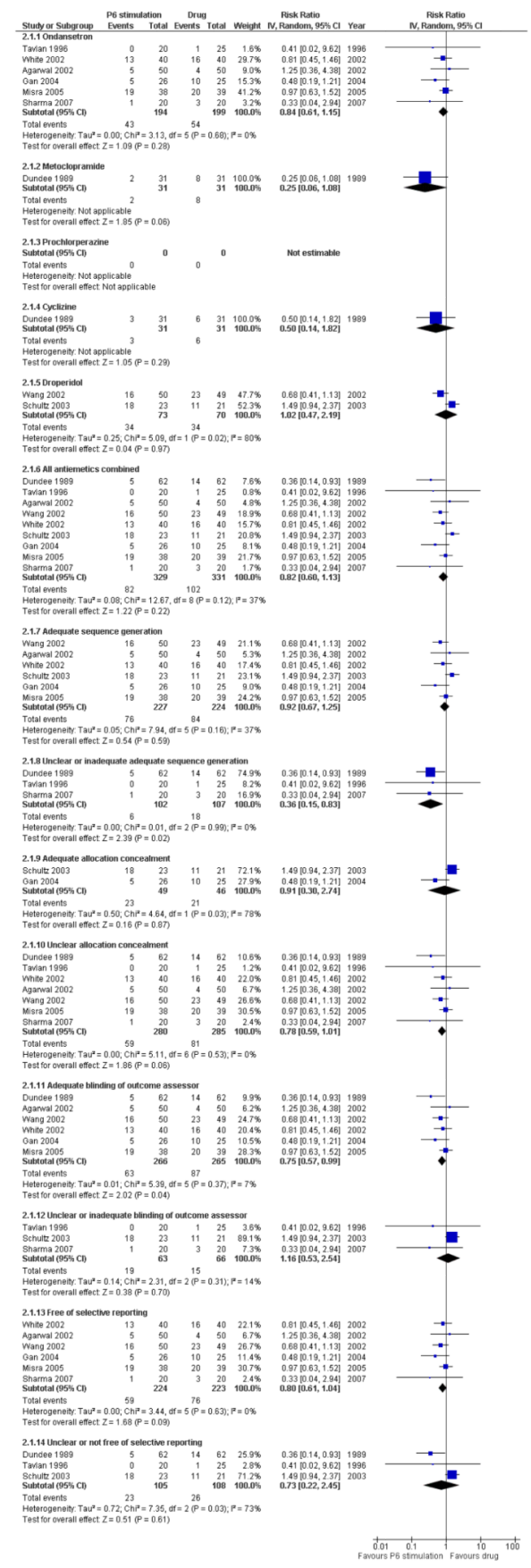

Figure 9.

Forest plot of comparison: 2 Acupoint P6 stimulation versus antiemetic, outcome: 2.1 Nausea. 


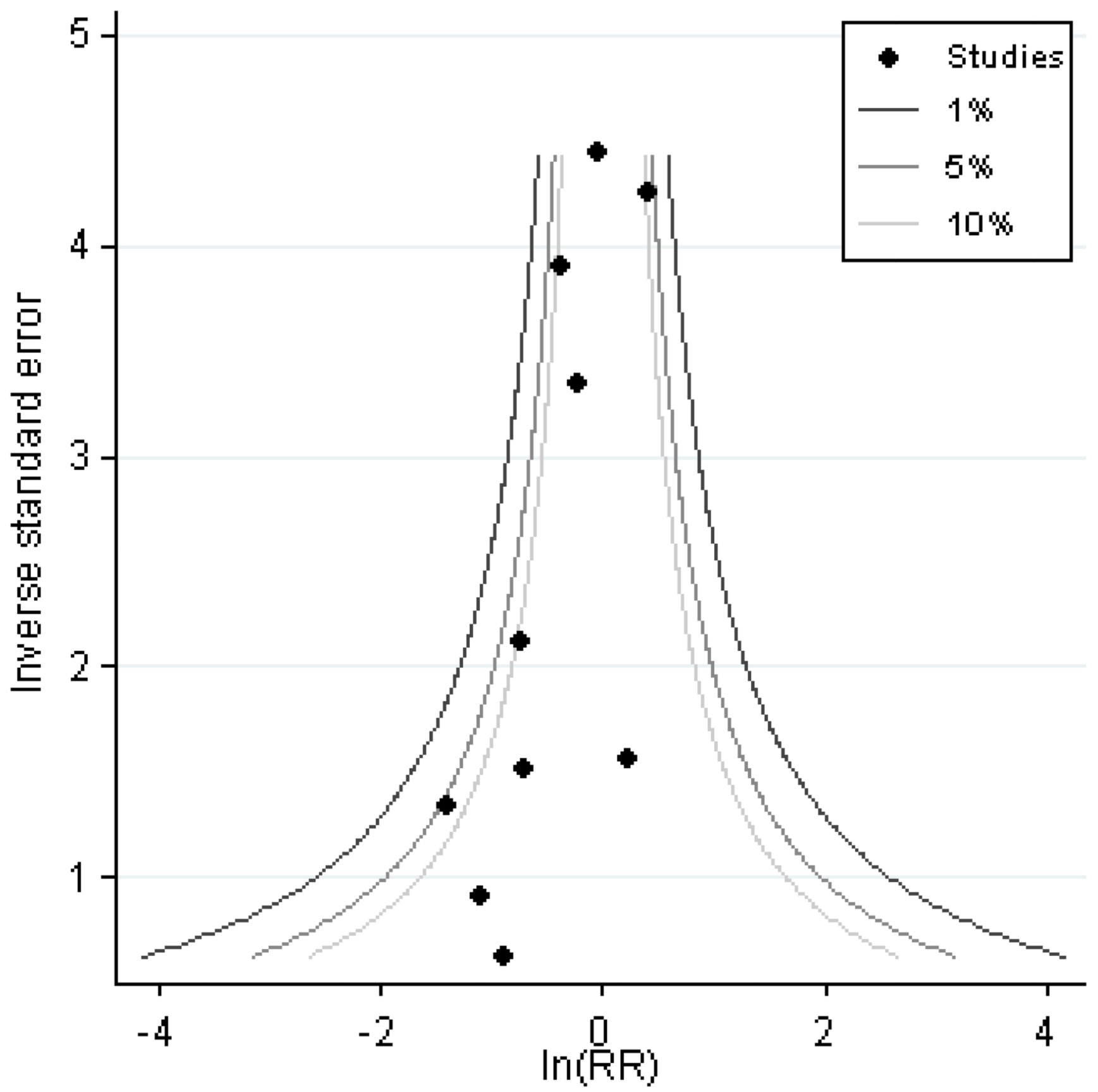

Figure 10.

Contour-enhanced funnel plot of comparison: 2 Acupoint P6 stimulation versus antiemetic, outcome: 2.1 Nausea. Contour lines are at $1 \%, 5 \%$ and $10 \%$ levels of statistical significance. 


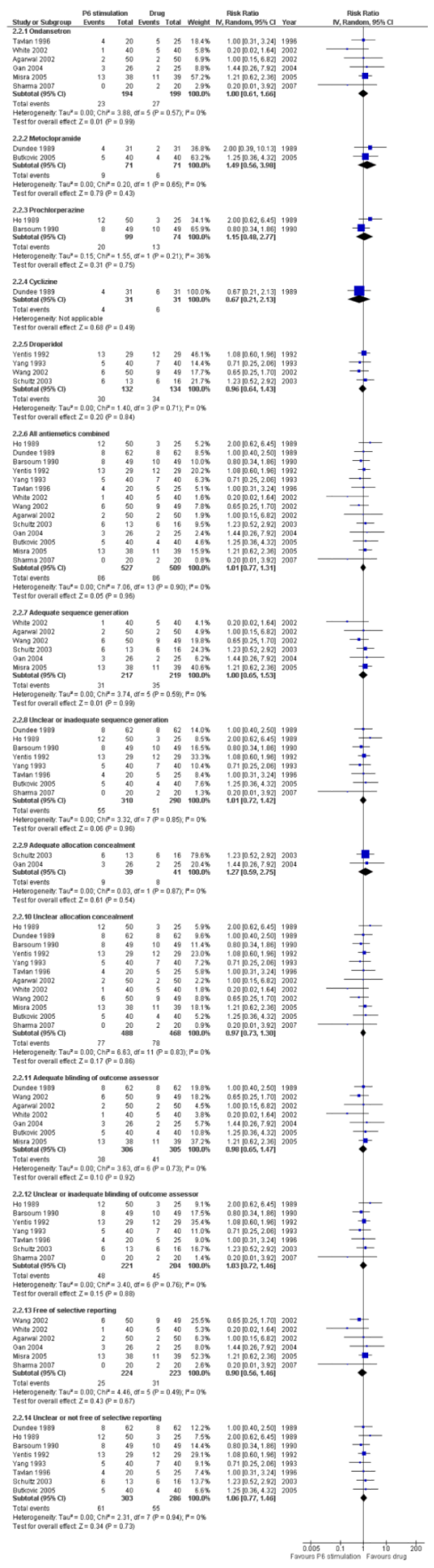

Figure 11.

Forest plot of comparison: 2 Acupoint P6 stimulation versus antiemetic, outcome: 2.2 Vomiting. 


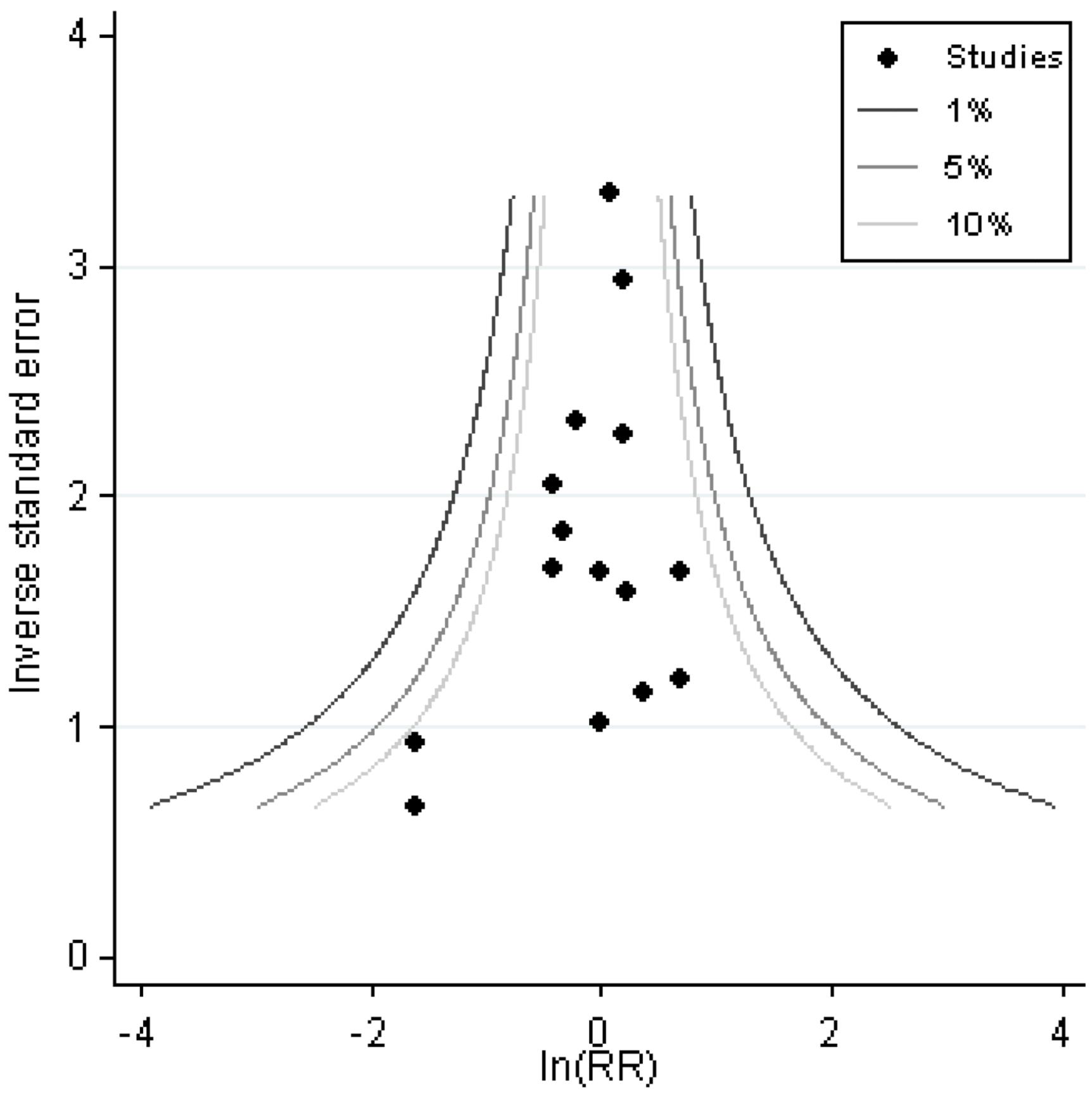

Figure 12.

Contour-enhanced funnel plot of comparison: 2 Acupoint P6 stimulation versus antiemetic, outcome: 2.2 Vomiting. Contour lines are at $1 \%, 5 \%$ and $10 \%$ levels of statistical significance. 


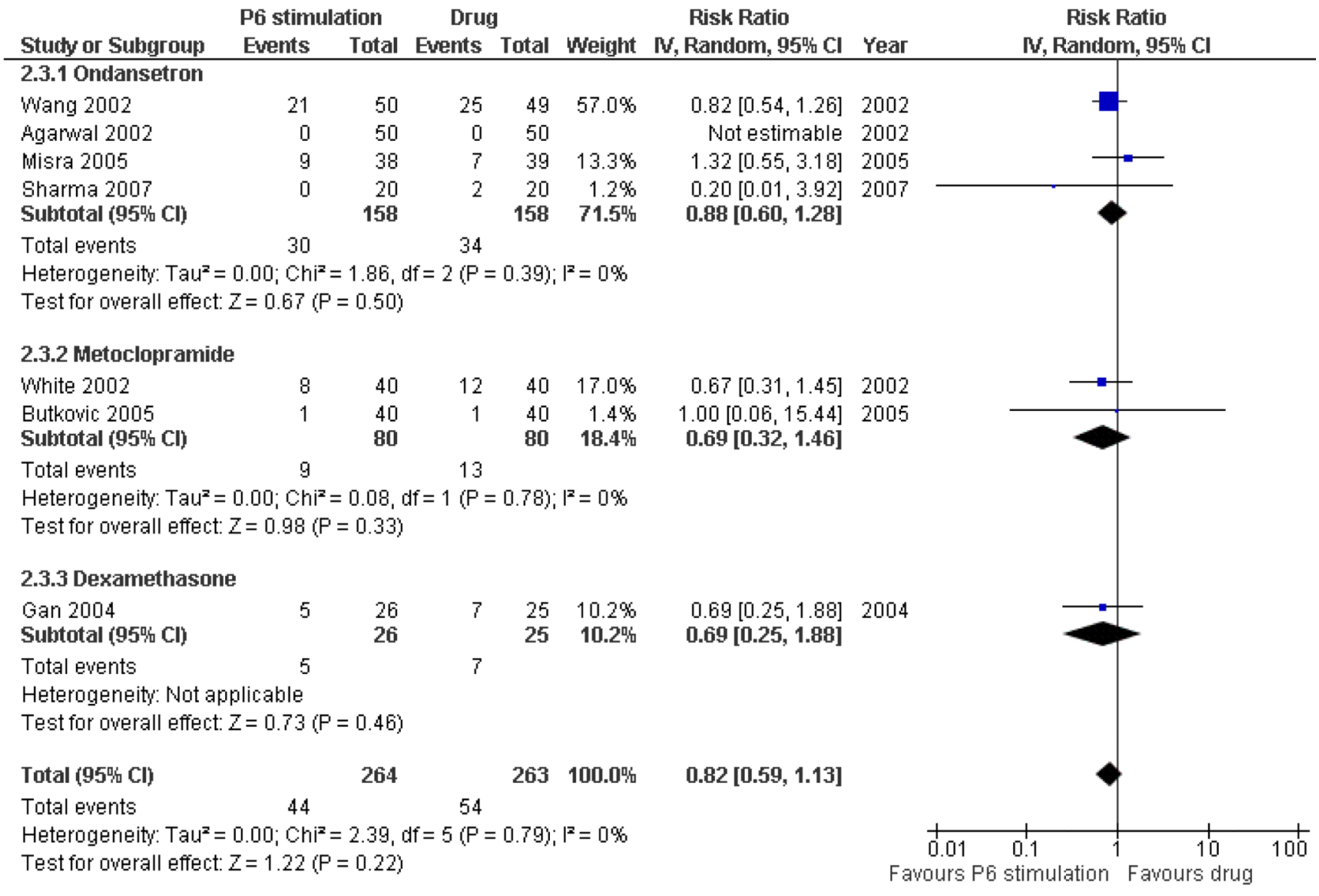

Figure 13.

Forest plot of comparison: 2 Acupoint P6 stimulation versus antiemetic, outcome: 2.3

Rescue antiemetic. 
Table 1

Estimated NNT for preventing PONV (P6 acupoint stimulation versus sham)

\begin{tabular}{l|l|l|l|l}
\hline Control event rate & Nausea & $\mathbf{9 5 \%}$ CI & Vomiting & $\mathbf{9 5 \%}$ CI \\
\hline $10 \%$ & 34 & 26 to 59 & 33 & 24 to 59 \\
\hline $20 \%$ & 17 & 13 to 29 & 17 & 12 to 29 \\
\hline $30 \%$ & 11 & 9 to 20 & 11 & 8 to 20 \\
\hline $40 \%$ & 9 & 6 to 15 & 8 & 6 to 15 \\
\hline $50 \%$ & 7 & 5 to 12 & 7 & 5 to 12 \\
\hline $60 \%$ & 6 & 4 to 10 & 6 & 4 to 10 \\
\hline $70 \%$ & 5 & 4 to 8 & 5 & 3 to 8 \\
\hline $80 \%$ & 4 & 3 to 7 & 4 & 3 to 7 \\
\hline $90 \%$ & 4 & 3 to 7 & 4 & 3 to 6 \\
\hline
\end{tabular}


CHARACTERISTICS OF STUDIES

Characteristics of included studies [ordered by study ID]

\begin{tabular}{|c|c|c|}
\hline \multicolumn{3}{|l|}{ Agarwal 2000} \\
\hline Methods & \multicolumn{2}{|c|}{$\begin{array}{l}\text { Patients assigned to groups by a computer-generated table of random numbers. All acupressure } \\
\text { wristbands were covered with gauze and tape. Outcome assessor blinded to treatment groups. }\end{array}$} \\
\hline Participants & \multicolumn{2}{|c|}{$\begin{array}{l}200 \text { patients undergoing endoscopic urological surgery. Exclusion: patient refusal to participate in } \\
\text { study, previous history of PONV and motion sickness, impaired renal function with increased urea and } \\
\text { creatinine concentrations, diabetes mellitus, obesity, patients receiving antiemetic medication, histamine } \\
\text { H2-receptor antagonist within } 72 \text { hours of surgery. No patient withdrew from the study. }\end{array}$} \\
\hline Interventions & \multicolumn{2}{|c|}{$\begin{array}{l}\text { Acupressure wristband placed at P6 points on both forearms, applied } 30 \text { min before induction of } \\
\text { anaesthesia and removed after } 6 \text { hours following surgery. } \\
\text { Sham group was the spherical bead of acupressure wristbands placed on posterior surface, applied } 30 \\
\text { min before induction of anaesthesia and removed } 6 \text { hours after surgery. }\end{array}$} \\
\hline Outcomes & \multicolumn{2}{|c|}{ Nausea (0-24h), vomiting ( $0-24 \mathrm{~h})$, side effects of acupressure, risk of rescue antiemetic drug. } \\
\hline Notes & \multicolumn{2}{|c|}{ Rescue antiemetic was ondansetron $4 \mathrm{mg}$ IV. No side effects or complications noted in either group. } \\
\hline \multicolumn{3}{|l|}{ Risk of bias } \\
\hline Item & Authors' judgement & Description \\
\hline Adequate sequence generation? & Yes & $\begin{array}{l}\text { "Patients were assigned to two different groups } \\
\text { according to a computer-generated table of random } \\
\text { numbers". }\end{array}$ \\
\hline Allocation concealment? & Unclear & Insufficient information. \\
\hline $\begin{array}{l}\text { Incomplete outcome data } \\
\text { addressed? All outcomes }\end{array}$ & Yes & "No patient was excluded after admission to the study". \\
\hline Free of selective reporting? & Yes & All expected outcomes reported. \\
\hline Free of other bias? & Yes & $\begin{array}{l}\text { Baseline characteristics were comparable: "Patients } \\
\text { were comparable in both the groups as regards to age, } \\
\text { sex, height and weight". }\end{array}$ \\
\hline Blinding of patients? All outcomes & Unclear & Insufficient information. \\
\hline $\begin{array}{l}\text { Blinding of healthcare providers? } \\
\text { All outcomes }\end{array}$ & Unclear & Insufficient information. \\
\hline $\begin{array}{l}\text { Blinding of outcome assessor? All } \\
\text { outcomes }\end{array}$ & Unclear & Insufficient information. \\
\hline \multicolumn{3}{|l|}{ Agarwal 2002} \\
\hline Methods & \multicolumn{2}{|c|}{$\begin{array}{l}\text { Patients assigned using a table of random numbers. Outcome assessor blinded to treatment groups. } \\
\text { Acupressure and sham group received normal saline IV before induction to maintain blinding of the } \\
\text { treatment groups. }\end{array}$} \\
\hline Participants & \multicolumn{2}{|c|}{$\begin{array}{l}150 \text { adults undergoing laparoscopic cholecystectomy. Exclusion: patient refusal to participate in study, } \\
\text { previous history of PONV and motion sickness, impaired renal function with increased urea and } \\
\text { creatinine concentrations, diabetes mellitus, obesity, patients receiving antiemetic medication, histamine } \\
\text { H2-receptor antagonist within } 72 \text { hours of surgery. }\end{array}$} \\
\hline Interventions & \multicolumn{2}{|c|}{$\begin{array}{l}\text { Acupressure wristband placed at P6 points on both forearms, applied } 30 \text { min before induction of } \\
\text { anaesthesia and removed after } 6 \text { hours following surgery (plus normal saline } 1 \mathrm{~mL} \text { IV just before } \\
\text { induction of anaesthesia). } \\
\text { Sham group was the spherical bead of acupressure wristbands placed on posterior surface, applied } 30 \\
\text { min before induction of anaesthesia and removed } 6 \text { hours after surgery (plus normal saline } 1 \mathrm{~mL} \text { IV just } \\
\text { before induction of anaesthesia). } \\
\text { Antiemetic group was ondansetron } 4 \mathrm{mg} \text { IV just before induction of anaesthesia (plus sham treatment } \\
\text { outlined above). }\end{array}$} \\
\hline Outcomes & \multicolumn{2}{|c|}{ Nausea $(0-24 h)$, vomiting $(0-24 h)$, risk of rescue antiemetic drug. } \\
\hline Notes & \multicolumn{2}{|c|}{$\begin{array}{l}\text { Rescue antiemetic was ondansetron } 4 \mathrm{mg} \text { IV if patient vomited more than once. No side effects or } \\
\text { complications noted in any of the groups. Data for outcome }(0-24 \mathrm{~h}) \text { obtained by correspondence with } \\
\text { author. }\end{array}$} \\
\hline
\end{tabular}

Risk of bias 


\begin{tabular}{|c|c|c|}
\hline Item & Authors' judgement & Description \\
\hline Adequate sequence generation? & Yes & $\begin{array}{l}\text { "Patients were randomized into three groups of } 50 \text { each } \\
\text { using a table of random numbers..". }\end{array}$ \\
\hline Allocation concealment? & Unclear & Insufficient information. \\
\hline $\begin{array}{l}\text { Incomplete outcome data } \\
\text { addressed? All outcomes }\end{array}$ & Yes & No missing data reported for 150 patients randomized. \\
\hline Free of selective reporting? & Yes & All expected outcomes reported. \\
\hline Free of other bias? & Yes & $\begin{array}{l}\text { Baseline characteristics were comparable: "Patients } \\
\text { were comparable in both the groups as regards to age, } \\
\text { sex, height, weight and duration of surgery". }\end{array}$ \\
\hline Blinding of patients? All outcomes & Yes & $\begin{array}{l}\text { Authors took adequate steps to make interventions } \\
\text { appear similar. }\end{array}$ \\
\hline $\begin{array}{l}\text { Blinding of healthcare providers? } \\
\text { All outcomes }\end{array}$ & Unclear & Insufficient information. \\
\hline $\begin{array}{l}\text { Blinding of outcome assessor? All } \\
\text { outcomes }\end{array}$ & Yes & $\begin{array}{l}\text { "The incidence of PONV was evaluated by a blinded } \\
\text { observer". }\end{array}$ \\
\hline
\end{tabular}

Alkaissi 1999

Methods

Method of allocation concealment not given. Patients were asked to record nausea and vomiting during their stay in hospital and after discharge. Nurses who asked the patients about nausea and administered antiemetics on the postoperative ward were not aware of treatment allocation or where the P6 acupoint was located.

\section{Participants}

60 women undergoing day case minor gynaecological surgery. Exclusion: patients undergoing local anaesthesia and those given prophylactic antiemetic during anaesthesia $(n=10$, replaced by randomising another 10 patients at the end of the study).

Interventions

Acupressure wristband placed at P6 point on both forearms. Applied before surgery and left on for 24 hours. Draped with a dressing during the stay in the hospital.

Sham acupressure applied to dorsal side of forearms. Applied before surgery and left on for 24 hours. Draped with a dressing during the stay in the hospital.

Reference group were informed and anaesthetised in the same way as the other two groups.

\begin{tabular}{|c|c|c|}
\hline Outcomes & \multicolumn{2}{|c|}{ Nausea (0-24h), vomiting $(0-24 h)$, risk of rescue antiemetic drugs. } \\
\hline Notes & \multicolumn{2}{|c|}{$\begin{array}{l}\text { Rescue antiemetics were metoclopramide } 10 \mathrm{mg} \text { IV at patient's request; if not effective, then given } \\
\text { droperidol } 1.25 \mathrm{mg} \text { IV. Reference group received no treatment and was not included in data analysis. }\end{array}$} \\
\hline \multicolumn{3}{|l|}{ Risk of bias } \\
\hline Item & Authors' judgement & Description \\
\hline Adequate sequence generation? & Unclear & Insufficient information. \\
\hline Allocation concealment? & Unclear & Insufficient information. \\
\hline $\begin{array}{l}\text { Incomplete outcome data } \\
\text { addressed? All outcomes }\end{array}$ & Yes & $\begin{array}{l}\text { Reasons were given for } 10 \text { dropouts, who were } \\
\text { replaced by randomising another } 10 \text { patients at the end } \\
\text { of the study. "The dropouts were evenly distributed } \\
\text { between the groups." No missing data reported for } 60 \\
\text { patients analysed. }\end{array}$ \\
\hline Free of selective reporting? & No & $\begin{array}{l}\text { Primary outcome (PONV) reported. Description of side } \\
\text { effects not given. }\end{array}$ \\
\hline Free of other bias? & Yes & $\begin{array}{l}\text { Demographic data appeared to be comparable in Table } \\
1 .\end{array}$ \\
\hline Blinding of patients? All outcomes & Yes & $\begin{array}{l}\text { Authors took adequate steps to make interventions } \\
\text { appear similar. }\end{array}$ \\
\hline $\begin{array}{l}\text { Blinding of healthcare providers? } \\
\text { All outcomes }\end{array}$ & Yes & $\begin{array}{l}\text { "The nurses who asked the patients about nausea, and } \\
\text { administered antiemetics on the postoperative ward } \\
\text { were not aware of which treatment the patient received } \\
\text { or where the P6 acupoint is located". }\end{array}$ \\
\hline $\begin{array}{l}\text { Blinding of outcome assessor? All } \\
\text { outcomes }\end{array}$ & Yes & $\begin{array}{l}\text { "The nurses who asked the patients about nausea, and } \\
\text { administered antiemetics on the postoperative ward } \\
\text { were not aware of which treatment the patient received }\end{array}$ \\
\hline
\end{tabular}




\begin{tabular}{|c|c|c|}
\hline & & $\begin{array}{l}\text { or where the P6 acupoint is located". These nurses also } \\
\text { noted vomiting episodes. }\end{array}$ \\
\hline \multicolumn{3}{|l|}{ Alkaissi 2002} \\
\hline Methods & \multicolumn{2}{|c|}{$\begin{array}{l}\text { Patients randomized by sealed envelope (not opaque). Patients were asked to record nausea and } \\
\text { vomiting. Multicentre trial. Wrists were wrapped with dressing to maintain blinding (but patients may } \\
\text { have unwrapped the dressing). }\end{array}$} \\
\hline Participants & \multicolumn{2}{|c|}{$\begin{array}{l}410 \text { women undergoing elective gynaecological surgery. No exclusion criteria specified. Thirty patients } \\
\text { were withdrawn because they were: given local anaesthesia }(n=12) \text {, or an antiemetic was given without } \\
\text { the criteria for treatment of PONV being met }(n=14) \text {, malignant hyperthermia }(n=1) \text {, allergy to latex } \\
(n=2) \text {, and could not read Swedish }(n=1) \text {. These } 30 \text { patients were replaced by another } 30 \text { at the end of } \\
\text { the study period. }\end{array}$} \\
\hline Interventions & \multicolumn{2}{|c|}{$\begin{array}{l}\text { Acupressure wristband placed on P6 point on both forearms just before start of anaesthesia, left on for } \\
24 \text { hours. } \\
\text { Sham group included acupressure wristbands at non-acupoint on both forearms just before start of } \\
\text { anaesthesia, left on for } 24 \text { hours. } \\
\text { Reference group received no prophylactic treatment and was not blinded. }\end{array}$} \\
\hline Outcomes & \multicolumn{2}{|c|}{$\begin{array}{l}\text { Nausea (0-24h), vomiting ( } 0-24 \mathrm{~h}) \text {, side effects of acupressure, risk of rescue antiemetic (type of drug } \\
\text { not described) }\end{array}$} \\
\hline Notes & \multicolumn{2}{|c|}{$\begin{array}{l}\text { Reference group received no treatment and was not included in data analysis. Adverse effects: } \\
\text { wristbands felt uncomfortable, produced red indentation, or caused itching, headache and dizziness, or } \\
\text { wrists hurt and tightness of wristband caused swelling or deep marks or blistering at site of stud. }\end{array}$} \\
\hline \multicolumn{3}{|l|}{ Risk of bias } \\
\hline Item & Authors' judgement & Description \\
\hline Adequate sequence generation? & Unclear & Insufficient information. \\
\hline Allocation concealment? & Unclear & Insufficient information. \\
\hline $\begin{array}{l}\text { Incomplete outcome data } \\
\text { addressed? All outcomes }\end{array}$ & Yes & $\begin{array}{l}\text { Reasons were given for } 30 \text { dropouts, who were } \\
\text { replaced by randomizing another } 30 \text { patients at the end } \\
\text { of the study. "Withdrawals were evenly distributed } \\
\text { between the groups." No missing data reported for } 410 \\
\text { patients analysed. }\end{array}$ \\
\hline Free of selective reporting? & Yes & All expected outcomes reported. \\
\hline Free of other bias? & Yes & $\begin{array}{l}\text { Demographic data appeared to be comparable in Table } \\
2 .\end{array}$ \\
\hline Blinding of patients? All outcomes & Yes & $\begin{array}{l}\text { "The wrists were wrapped for blinding". Patients } \\
\text { reported outcomes. }\end{array}$ \\
\hline $\begin{array}{l}\text { Blinding of healthcare providers? } \\
\text { All outcomes }\end{array}$ & Unclear & Insufficient information. \\
\hline $\begin{array}{l}\text { Blinding of outcome assessor? All } \\
\text { outcomes }\end{array}$ & Yes & $\begin{array}{l}\text { "The wrists were wrapped for blinding". Patients } \\
\text { reported outcomes. }\end{array}$ \\
\hline \multicolumn{3}{|l|}{ Allen 1994} \\
\hline Methods & \multicolumn{2}{|c|}{$\begin{array}{l}\text { Method of allocation concealment not given. Outcome assessor was anaesthetist. Blinding not } \\
\text { mentioned. No patient withdrew from study. }\end{array}$} \\
\hline Participants & \multicolumn{2}{|c|}{$\begin{array}{l}46 \text { women undergoing gynaecological surgery. Exclusions: previous exposure to elasticised wristbands } \\
\text { for the prevention of motion sickness. }\end{array}$} \\
\hline Interventions & \multicolumn{2}{|c|}{$\begin{array}{l}\text { Acupressure wristband placed on P6 point of dominant arm before premedication ( } 90 \text { min before } \\
\text { surgery). Duration of treatment not given. } \\
\text { Sham acupressure wristband placed on dorsum of dominant wrist before premedication. Duration of } \\
\text { treatment not given. }\end{array}$} \\
\hline Outcomes & \multicolumn{2}{|c|}{ Nausea (0-24h), vomiting $(0-24 h)$} \\
\hline Notes & \multicolumn{2}{|c|}{$\begin{array}{l}\text { Rescue antiemetic was prochlorperazine } 12.5 \mathrm{mg} \text { IM } 4 \text { hourly when necessary. More than one dose of } \\
\text { prochlorperazine data given (not included in data analysis). }\end{array}$} \\
\hline \multicolumn{3}{|l|}{ Risk of bias } \\
\hline Item & Authors' judgement & Description \\
\hline Adequate sequence generation? & Unclear & Insufficient information. \\
\hline
\end{tabular}




\begin{tabular}{|c|c|c|}
\hline Allocation concealment? & Unclear & Insufficient information. \\
\hline $\begin{array}{l}\text { Incomplete outcome data } \\
\text { addressed? All outcomes }\end{array}$ & Yes & $\begin{array}{l}\text { "No patient refused to participate in the study, nor were } \\
\text { there any withdrawals". }\end{array}$ \\
\hline Free of selective reporting? & No & $\begin{array}{l}\text { Risk of rescue antiemetic drug (one or more dose) was } \\
\text { not given in the results. Description of side effects not } \\
\text { reported. }\end{array}$ \\
\hline Free of other bias? & Yes & $\begin{array}{l}\text { Baseline characteristics were comparable. "The ages } \\
\text { and weights of the patients in the two groups were } \\
\text { comparable...". }\end{array}$ \\
\hline Blinding of patients? All outcomes & Yes & $\begin{array}{l}\text { Authors took adequate steps to make interventions } \\
\text { appear similar in patients with no previous experience } \\
\text { with this form of acupressure. }\end{array}$ \\
\hline $\begin{array}{l}\text { Blinding of healthcare providers? } \\
\text { All outcomes }\end{array}$ & Unclear & Insufficient information. \\
\hline $\begin{array}{l}\text { Blinding of outcome assessor? All } \\
\text { outcomes }\end{array}$ & Unclear & Insufficient information. \\
\hline \multicolumn{3}{|l|}{ Amir 2007} \\
\hline Methods & \multicolumn{2}{|c|}{$\begin{array}{l}\text { Method of allocation concealment was not given. Subjects were randomly assigned to groups using } \\
\text { computer-generated random number table. Outcome assessor was blinded but no details about blinding } \\
\text { for subjects and attending anaesthetist. }\end{array}$} \\
\hline Participants & \multicolumn{2}{|c|}{$\begin{array}{l}40 \text { children and adults undergoing middle ear surgery. Patients with cardiovascular disease, central } \\
\text { nervous system problems, previous history of PONV and/or motion sickness, and smokers were } \\
\text { excluded. No details about withdrawals or loss to follow up. }\end{array}$} \\
\hline Interventions & \multicolumn{2}{|c|}{$\begin{array}{l}\text { Group 1: electro-acupuncture at frequency of } 4 \mathrm{~Hz} \text { and current intensity increased to a degree just less } \\
\text { than what caused discomfort, given } 20 \text { min before induction for duration of surgery. } \\
\text { Group 2: sham electro-acupuncture. No details given except that patients experienced needle pricks. }\end{array}$} \\
\hline Outcomes & \multicolumn{2}{|c|}{ Nausea $(0-24 \mathrm{~h})$, vomiting $(0-24 \mathrm{~h})$, risk of rescue antiemetic drug $(0-24 \mathrm{~h})$, risk of adverse effects. } \\
\hline Notes & \multicolumn{2}{|c|}{$\begin{array}{l}\text { Rescue antiemetic was ondansetron } 4 \mathrm{mg} \text { IV after first episode of PONV and repeated when necessary } \\
\text { at } 6 \text { hourly intervals. No side effects in sham electro-acupuncture group. Erythema occurred in } 3 \\
\text { patients in the electro-acupuncture group. }\end{array}$} \\
\hline \multicolumn{3}{|l|}{ Risk of bias } \\
\hline Item & Authors' judgement & Description \\
\hline Adequate sequence generation? & Yes & $\begin{array}{l}\text { "Informed consent was taken from the selected patients } \\
\text { and they were divided into two groups of twenty each" } \\
\text { using a computer-generated table of random numbers". }\end{array}$ \\
\hline Allocation concealment? & Unclear & Insufficient information. \\
\hline $\begin{array}{l}\text { Incomplete outcome data } \\
\text { addressed? All outcomes }\end{array}$ & Yes & $\begin{array}{l}\text { No missing data reported for the } 20 \text { patients } \\
\text { randomized. }\end{array}$ \\
\hline Free of selective reporting? & Yes & All expected outcomes reported. \\
\hline Free of other bias? & Yes & $\begin{array}{l}\text { Baseline characteristics were comparable. "Differences } \\
\text { in mean age, weight, sex and duration of surgery were } \\
\text { statistically insignificant". }\end{array}$ \\
\hline Blinding of patients? All outcomes & Unclear & Insufficient information. \\
\hline $\begin{array}{l}\text { Blinding of healthcare providers? } \\
\text { All outcomes }\end{array}$ & Unclear & Insufficient information. \\
\hline $\begin{array}{l}\text { Blinding of outcome assessor? All } \\
\text { outcomes }\end{array}$ & Yes & $\begin{array}{l}\text { "A blinded observed collected postoperative data of } \\
\text { PONV". }\end{array}$ \\
\hline \multicolumn{3}{|l|}{ Andrzejowski 1996} \\
\hline Methods & \multicolumn{2}{|c|}{ Randomization by sealed envelope (not opaque). Patients asked to record nausea and vomiting. } \\
\hline Participants & \multicolumn{2}{|c|}{$\begin{array}{l}36 \text { women undergoing total abdominal hysterectomy. Exclusions: metal or elastoplast allergy, } \\
\text { anticoagulant therapy, local skin disease at P6 acupoint or sham point, or chronic treatment with } \\
\text { antiemetics. }\end{array}$} \\
\hline
\end{tabular}


Interventions

Semipermanent acupuncture needle inserted at P6 acupoint on both wrists 20 min before induction, left in place until second postoperative day.

Sham semipermanent acupuncture needle inserted in sham point $20 \mathrm{~min}$ before induction, left in place until second postoperative day.

\begin{tabular}{l|l}
\hline Outcomes & Nausea $(0-8 \mathrm{~h})$, vomiting $(0-8 \mathrm{~h})$, risk of antiemetic rescue drug, side effects. \\
\hline Notes & $\begin{array}{l}\text { Antiemetic rescue was prochlorperazine } 12.5 \mathrm{mg} \text { IM when necessary. No side effects reported with } \\
\text { interventions. }\end{array}$ \\
\hline Risk of bias &
\end{tabular}

\begin{tabular}{l|l|l}
\hline Item & Authors' judgement & Description \\
\hline Adequate sequence generation? & Unclear & $\begin{array}{l}\text { Insufficient information. "Patients were allocated } \\
\text { randomly into one of two groups". }\end{array}$ \\
\hline Allocation concealment? & Unclear & $\begin{array}{l}\text { Insufficient information. "This was achieved by } \\
\text { concealing the assignment schedule in sealed envelopes } \\
\text { which were opened by the investigator just before } \\
\text { inserting the needles". Comment: not sure if envelopes } \\
\text { were sequentially numbered and opaque. }\end{array}$ \\
\hline $\begin{array}{l}\text { Incomplete outcome data } \\
\text { addressed? All outcomes }\end{array}$ & Yes & No missing data reported for 36 patients randomized. \\
\hline Free of selective reporting? & Yes & All expected outcomes reported. \\
\hline Free of other bias? & Yes & $\begin{array}{l}\text { Baseline characteristics were comparable. "There was } \\
\text { no significant difference between the two groups in } \\
\text { age, weight, total morphine consumed, or duration of } \\
\text { anaesthesia". }\end{array}$ \\
\hline Blinding of patients? All outcomes & Yes & $\begin{array}{l}\text { The assessments were made by the patients, who were } \\
\text { blinded to their treatment“. }\end{array}$ \\
\hline $\begin{array}{l}\text { Blinding of healthcare providers? } \\
\text { All outcomes }\end{array}$ & Unclear & Insufficient information. \\
\hline $\begin{array}{l}\text { Blinding of outcome assessor? All } \\
\text { outcomes }\end{array}$ & Yes & $\begin{array}{l}\text { The assessments were made by the patients, who were } \\
\text { blinded to their treatment". }\end{array}$ \\
\hline
\end{tabular}

Arnberger 2007

Methods

Patients were assigned to groups using a set of computer-generated random numbers. The assignments were kept in sealed, sequentially numbered envelopes. Patients and outcome assessors were unaware of group assignment. The attending anaesthetist could not be blinded to the group assignment but was not involved in outcome assessments.

Participants

220 females undergoing elective gynaecological and abdominal laparoscopic surgery of more than 1 hour duration. Exclusion: pregnant and breast-feeding women, and patients with eating disorders, obesity (body mass index $>35 \mathrm{~kg} / \mathrm{m}^{2}$ ), severe renal or liver impairment, central nervous system injury, vertebrobasilar artery insufficiency, vestibular disease, cytostatic therapy, and preoperative vomiting or antiemetic therapy. No patient withdrew from study.

\begin{tabular}{l|l}
\hline Interventions & P6 group: during anaesthesia, neuromuscular blockade was monitored by a conventional nerve
\end{tabular} stimulator at a frequency of $1 \mathrm{~Hz}$ over the median nerve (first electrode $1 \mathrm{~cm}$ proximal to $\mathrm{P} 6$ acupoint and second electrode placed $2 \mathrm{~cm}$ distal to the P6 acupoint) on the dominant hand.

Sham group: during anaesthesia, neuromuscular blockade was monitored by a conventional nerve stimulator at a frequency of $1 \mathrm{~Hz}$ over the ulnar nerve (first electrode $1 \mathrm{~cm}$ proximal to the point at which the proximal flexion crease of the wrist crosses the radial side of the tendon to the flexor carpi ulnaris muscle at the volar side of the wrist and second electrode placed $3 \mathrm{~cm}$ proximal to the distal electrode) on the dominant hand.

\begin{tabular}{l|l}
\hline Outcomes & Nausea (0-24h), vomiting (0-24h), risk of rescue antiemetic drug (0-24h), risk of adverse effects. \\
\hline Notes & $\begin{array}{l}\text { Rescue antiemetic was ondansetron } 4 \mathrm{mg} \text { IV if } 2 \text { or more episodes of vomiting or persistent nausea; } \\
\text { with repetition after } 2 \text { hours. No local irritation, redness, contact dermatitis or muscle ache (side effects) } \\
\text { were recorded. Nausea (0-6h), vomiting }(0-6 \mathrm{~h}), \text { and incidence of rescue antiemetic (0-6h) also } \\
\text { reported. }\end{array}$ \\
\hline
\end{tabular}

\section{Risk of bias}

\begin{tabular}{l|l|l} 
Item & Authors' judgement & Description \\
\hline Adequate sequence generation? & Yes & $\begin{array}{l}\text { "After induction of anaesthesia, patients were assigned } \\
\text { to one of two groups using a set of computer-generated } \\
\text { random numbers". }\end{array}$ \\
\hline
\end{tabular}




\begin{tabular}{l|l|l} 
Allocation concealment? & Yes & $\begin{array}{l}\text { "The assignments were kept in sealed, sequentially } \\
\text { numbered envelopes until used, and the envelope } \\
\text { numbers with the assignment were recorded". }\end{array}$ \\
\hline $\begin{array}{l}\text { Incomplete outcome data } \\
\text { addressed? All outcomes }\end{array}$ & Yes & $\begin{array}{l}\text { "Two hundred twenty patients were recruited for this } \\
\text { study without any dropout over the observation } \\
\text { period". }\end{array}$ \\
\hline Free of selective reporting? & Yes & All expected outcomes reported. \\
\hline Free of other bias? & Yes & $\begin{array}{l}\text { Baseline characteristics were comparable. } \\
\text { "Demographic and morphometric characteristics and } \\
\text { factors likely to influence PONV were similar in the } \\
\text { two groups (Table 1)". }\end{array}$ \\
\hline Blinding of patients? All outcomes & Yes & $\begin{array}{l}\text { "Patients and PONV evaluators were not informed of } \\
\text { the group assignments". }\end{array}$ \\
\hline $\begin{array}{l}\text { Blinding of healthcare providers? } \\
\text { All outcomes }\end{array}$ & No & $\begin{array}{l}\text { "The attending anaesthesiologist could not be blinded } \\
\text { to the group assignment, but he or she was not involved } \\
\text { with the PONV assessment". }\end{array}$ \\
\hline $\begin{array}{l}\text { Blinding of outcome assessor? All } \\
\text { outcomes }\end{array}$ & Yes & $\begin{array}{l}\text { "Patients and PONV evaluators were not informed of } \\
\text { the group assignments". }\end{array}$ \\
\hline Basorm & &
\end{tabular}

\begin{tabular}{l|l}
\hline Barsoum 1990 & \multicolumn{2}{l}{ Rethods } & $\begin{array}{l}\text { Randomization by 'envelope system'. No details about whether outcome assessor was blinded or not. } \\
\text { Active and inactive acupressure wristbands were worn in the recovery room until discharge from } \\
\text { hospital, or for seven days if that was sooner (exact duration of intervention in hours not reported). }\end{array}$ \\
\hline Participants & $\begin{array}{l}162 \text { patients undergoing general surgery. Ten patients withdrew because of language or age difficulty } \\
\text { with completing analogue score, premature removal of wristbands, and incomplete follow-up data. }\end{array}$ \\
\hline Interventions & $\begin{array}{l}\text { Acupressure wristbands placed on P6 acupoint of both wrists in the recovery room. } \\
\text { Sham acupressure wristbands (no studs) were applied to both wrists in the recovery room and } \\
\text { antiemetics given only if clinically required. } \\
\text { Antiemetic group was given prochlorperazine } 12.5 \text { mg IM with each postoperative opiate injection and } \\
\text { when clinically required, and wore an acupressure band without stud on both wrists in the recovery } \\
\text { room. }\end{array}$ \\
\hline Outcomes & Vomiting (0-24h), risk of rescue antiemetic (prochlorperazine). \\
\hline Notes & $\begin{array}{l}\text { Nausea scores were reported for those patients who could not eat. Number of patients who were free of } \\
\text { nausea was not given. Vomiting on postoperative day 2 and } 3 \text { also reported. Four patients reported some } \\
\text { local tightness and discomfort (one of these experienced carpal tunnel like symptoms). }\end{array}$ \\
\hline
\end{tabular}

Risk of bias

\begin{tabular}{l|l|l} 
Item & Authors' judgement & Description \\
\hline Adequate sequence generation? & Unclear & Insufficient information. \\
\hline Allocation concealment? & Unclear & Insufficient information. \\
\hline $\begin{array}{l}\text { Incomplete outcome data } \\
\text { addressed? All outcomes }\end{array}$ & Yes & $\begin{array}{l}\text { Reasons for withdrawals were given. No missing data } \\
\text { reported for the 152 patients analysed. }\end{array}$ \\
\hline Free of selective reporting? & No & $\begin{array}{l}\text { Severity of nausea was reported but risk of nausea was } \\
\text { not. }\end{array}$ \\
\hline Free of other bias? & Yes & $\begin{array}{l}\text { Baseline characteristics appeared to be comparable. "It } \\
\text { can be seen that the groups were comparable with } \\
\text { regard to the range of operation and anaesthetic agents } \\
\text { used". }\end{array}$ \\
\hline $\begin{array}{l}\text { Blinding of patients? All outcomes } \\
\text { Alinding of healthcare providers? }\end{array}$ & Yes & $\begin{array}{l}\text { Authors took adequate steps to make interventions } \\
\text { appear similar and all patients were told that they were } \\
\text { wearing wristbands to try to prevent PONV. }\end{array}$ \\
\hline $\begin{array}{l}\text { Blinding of outcome assessor? All } \\
\text { outcomes }\end{array}$ & Unclear & Insufficient information. \\
\hline Butovic 2005 & Insufficient information. \\
\hline
\end{tabular}

Butkovic 2005 


\begin{tabular}{l|l} 
Methods & $\begin{array}{l}\text { Method of allocation concealment not given. "Researchers were double-blinded" but no specific details } \\
\text { about how blinding was achieved. }\end{array}$ \\
\hline Participants & $\begin{array}{l}120 \text { children (5-14 years) undergoing hernia repair, circumcision, or orchidopexy. Exclusion: patients } \\
\text { predisposed to nausea and vomiting secondary to gastroesophageal reflux, motion sickness, and inner } \\
\text { ear or central nervious system disorders. }\end{array}$ \\
\hline Interventions & $\begin{array}{l}\text { Group 1: laser acupuncture on P6 acupoint bilaterally for } 1 \mathrm{~min}, 15 \text { min before induction of anaesthesia } \\
\text { and IV infusion of saline. } \\
\text { Group 2: metoclopramide } 0.15 \mathrm{mg} / \mathrm{kg} \text { IV and sham laser on P6 acupoint bilaterally for } 1 \mathrm{~min}, 15 \mathrm{~min} \\
\text { before induction of anaesthesia. } \\
\text { Group 3: sham laser stimulation on P6 acupoint bilaterally for } 1 \mathrm{~min}, 15 \text { min before induction of } \\
\text { anaesthesia and saline infusion. }\end{array}$ \\
\hline Outcomes & Vomiting $(0-2 \mathrm{~h})$, risk of rescue antiemetic drug. \\
\hline Notes & Rescue antiemetic was ondansetron $0.1 \mathrm{mg} / \mathrm{kg}$ IV if vomiting was severe. \\
\hline
\end{tabular}

\section{Risk of bias}

\begin{tabular}{l|l|l}
\hline Item & Authors' judgement & Description \\
\hline Adequate sequence generation? & Unclear & Insufficient information. \\
\hline Allocation concealment? & Unclear & Insufficient information. \\
\hline $\begin{array}{l}\text { Incomplete outcome data } \\
\text { addressed? All outcomes }\end{array}$ & Yes & No missing data reported for the 120 children analysed. \\
\hline Free of selective reporting? & No & $\begin{array}{l}\text { Description of side effects not included. Nausea not } \\
\text { reported because it may be difficult to assess in } \\
\text { children. }\end{array}$ \\
\hline Free of other bias? & $\begin{array}{l}\text { Baseline characteristics were comparable. } \\
\text { "Demographic data showed no significant difference } \\
\text { among groups". }\end{array}$ \\
\hline Blinding of patients? All outcomes & Yes & $\begin{array}{l}\text { Authors took adequate steps to make intervention } \\
\text { appear similar. }\end{array}$ \\
\hline $\begin{array}{l}\text { Blinding of healthcare providers? } \\
\text { All outcomes }\end{array}$ & Yes & $\begin{array}{l}\text { "Researchers were double-blinded" but no specific } \\
\text { details about how blinding was achieved. Comment: } \\
\text { probably done. }\end{array}$ \\
\hline $\begin{array}{l}\text { Blinding of outcome assessor? All } \\
\text { outcomes }\end{array}$ & Yes & $\begin{array}{l}\text { "Researchers were double-blinded" but no specific } \\
\text { details about how blinding was achieved. Comment: } \\
\text { probably done. }\end{array}$ \\
\hline
\end{tabular}

\begin{tabular}{|c|c|c|}
\hline \multicolumn{3}{|l|}{ Duggal 1998} \\
\hline Methods & \multicolumn{2}{|c|}{$\begin{array}{l}\text { A table of random numbers was used to allocate patients into treatment groups. Patient, anaesthetist, } \\
\text { and investigators were unaware of treatment groups during the study. Patients recorded outcome } \\
\text { measures on a questionnaire. }\end{array}$} \\
\hline Participants & \multicolumn{2}{|c|}{$\begin{array}{l}263 \text { patients undergoing spinal anaesthesia for elective Caesarean delivery. Excluded: patients with a } \\
\text { history of hyperemesis gravidarum or if they had received antiemetic medication during the } 48 \mathrm{~h} \text { before } \\
\text { surgery. Eight women excluded for failing to wear wristbands for } 10 \text { hours, three had received } \\
\text { prophylactic antiemetics, and eight were not given standard combination of intrathecal drugs (total } 19 \\
\text { withdrawals). }\end{array}$} \\
\hline Interventions & \multicolumn{2}{|c|}{$\begin{array}{l}\text { Acupressure wristbands were applied to both wrists just before induction of spinal anaesthesia and worn } \\
\text { for } 10 \text { hours. } \\
\text { Sham acupressure wristbands were applied at P6 acupoint (but stud missing) on both wrists just before } \\
\text { induction of spinal anaesthesia and worn for } 10 \text { hours. }\end{array}$} \\
\hline Outcomes & \multicolumn{2}{|c|}{$\begin{array}{l}\text { Nausea (0-10h), vomiting }(0-10 \mathrm{~h}) \text {, risk of rescue antiemetic (type of drug not given), side effects of } \\
\text { acupressure. }\end{array}$} \\
\hline Notes & \multicolumn{2}{|c|}{$\begin{array}{l}\text { Adverse effects of acupressure wristbands: tightness, swollen hands, problems with infusion, itching } \\
\text { wrists. Intraoperative nausea and vomiting reported. }\end{array}$} \\
\hline \multicolumn{3}{|l|}{ Risk of bias } \\
\hline Item & Authors' judgement & Description \\
\hline Adequate sequence generation? & Yes & $\begin{array}{l}\text { "A table of random numbers was used to allocate } \\
\text { patients to one of two groups". }\end{array}$ \\
\hline
\end{tabular}




\begin{tabular}{l|l|l} 
Allocation concealment? & Unclear & Insufficient information. \\
\hline $\begin{array}{l}\text { Incomplete outcome data } \\
\text { addressed? All outcomes }\end{array}$ & Yes & $\begin{array}{l}\text { Reasons for withdrawals were given. No missing data } \\
\text { reported for the 244 patients analysed. }\end{array}$ \\
\hline Free of selective reporting? & Yes & All expected outcomes reported. \\
\hline Free of other bias? & Yes & $\begin{array}{l}\text { Baseline characteristics were comparable. } \\
\text { "Demographic analysis revealed no statistically } \\
\text { significant difference between subjects in the two } \\
\text { groups (Table 1)". }\end{array}$ \\
\hline Blinding of patients? All outcomes & Yes & $\begin{array}{l}\text { "The nature of the bands was therefore unknown to the } \\
\text { patient, anaesthetist and investigators for the duration } \\
\text { of the study". }\end{array}$ \\
\hline $\begin{array}{l}\text { Blinding of healthcare providers? } \\
\text { All outcomes }\end{array}$ & Yes & $\begin{array}{l}\text { "The nature of the bands was therefore unknown to the } \\
\text { patient, anaesthetist and investigators for the duration } \\
\text { of the study". }\end{array}$ \\
\hline $\begin{array}{l}\text { Blinding of outcome assessor? All } \\
\text { outcomes }\end{array}$ & Yes & $\begin{array}{l}\text { "The nature of the bands was therefore unknown to the } \\
\text { patient, anaesthetist and investigators for the duration } \\
\text { of the study". }\end{array}$ \\
\hline
\end{tabular}

Dundee 1986

\begin{tabular}{l|l}
\hline Methods & Method of allocation concealment not given. Outcome assessor was blinded to treatment groups. \\
\hline Participants & 75 women undergoing minor gynaecological surgery. \\
\hline Interventions & $\begin{array}{l}\text { Group 1: acupuncture at P6 acupoint with } 5 \text { min manual stimulation }(1.2 \mathrm{~cm} 30 \text { gauge needle) after } \\
\text { premedication with nalbuphine } 10 \mathrm{mg} .\end{array}$ \\
$\begin{array}{l}\text { Group 2: sham acupuncture at a dummy point on lateral elbow crease with } 5 \text { min manual stimulation } \\
1.2 \mathrm{~cm} \mathrm{30} \mathrm{gauge} \mathrm{needle)} \mathrm{after} \mathrm{premedication} \mathrm{with} \mathrm{nalbuphine} 10 \mathrm{mg} . \\
\text { Group 3: no further treatment after premedication with nalbuphine } 10 \mathrm{mg} .\end{array}$ \\
\hline Outcomes & Nausea (0-6h), vomiting (0-6h), side effects of treatment. \\
\hline Notes & $\begin{array}{l}\text { No side effects noted in either group. Group } 3 \text { data were excluded from data-analysis. Presence or } \\
\text { absence of needle marks and its location may have been observed by the outcome assessor. }\end{array}$ \\
\hline
\end{tabular}

\section{Risk of bias}

\begin{tabular}{|c|c|c|}
\hline Item & Authors' judgement & Description \\
\hline Adequate sequence generation? & Unclear & Insufficient information. \\
\hline Allocation concealment? & Unclear & Insufficient information. \\
\hline $\begin{array}{l}\text { Incomplete outcome data } \\
\text { addressed? All outcomes }\end{array}$ & Yes & No missing data reported for 75 patients analysed. \\
\hline Free of selective reporting? & Unclear & $\begin{array}{l}\text { No details about the use of rescue antiemetic in } \\
\text { anaesthetic protocol. The risk of rescue antiemetic drug } \\
\text { not reported. }\end{array}$ \\
\hline Free of other bias? & Yes & $\begin{array}{l}\text { "The groups were comparable in average age, weight, } \\
\text { and duration of anaesthesia". }\end{array}$ \\
\hline Blinding of patients? All outcomes & Yes & $\begin{array}{l}\text { The authors took adequate steps to make interventions } \\
\text { appear similar. }\end{array}$ \\
\hline $\begin{array}{l}\text { Blinding of healthcare providers? } \\
\text { All outcomes }\end{array}$ & Unclear & Insufficient information. \\
\hline $\begin{array}{l}\text { Blinding of outcome assessor? All } \\
\text { outcomes }\end{array}$ & Yes & $\begin{array}{l}\text { "Their assessments were performed by an observer } \\
\text { who was unaware of which patients had undergone } \\
\text { acupuncture". }\end{array}$ \\
\hline \multicolumn{3}{|l|}{ Dundee 1989} \\
\hline Methods & \multicolumn{2}{|c|}{$\begin{array}{l}\text { Method of allocation concealment not given. Outcome assessor was blinded to treatment group, except } \\
\text { where the patient pointed to the P6 acupoint site. }\end{array}$} \\
\hline Participants & \multicolumn{2}{|c|}{155 women undergoing minor gynaecological surgery. } \\
\hline Interventions & \multicolumn{2}{|c|}{$\begin{array}{l}\text { Acupuncture at P6 acupoint with } 5 \mathrm{~min} \text { manual stimulation after premedication. } \\
\text { Electroacupuncture at P6 acupoint for } 5 \mathrm{~min} \text { after premedication. } \\
\text { Antiemetic group } 1 \text { had cyclizine } 50 \mathrm{mg} \text { IM after premedication. }\end{array}$} \\
\hline
\end{tabular}


Antiemetic group 2 had metoclopramide $10 \mathrm{mg}$ IM after premedication.

Reference group had no treatment.

\begin{tabular}{ll}
\hline Outcomes & Nausea (0-6h), vomiting (0-6h), side effects of treatment. \\
\hline Notes & $\begin{array}{l}\text { For data analysis purposes, manual acupuncture and electro-acupuncture were combined. Reference } \\
\text { group received no treatment and was not included in data analysis. This paper reported both controlled } \\
\text { and uncontrolled studies of P6 stimulation. Used original data from Dundee JW, Fitzpatrick KTJ, Ghaly } \\
\text { RG. Is there a role for acupuncture in the treatment of postoperative nausea and vomiting? } \\
\text { Anesthesiology 1987; 67: 3A P165. This trial appears to be a duplicate of a previous published study: } \\
\text { Ghaly RG, Fitzpatrick KTJ, Dundee JW. Antiemetic studies with traditional Chinese acupuncture-a } \\
\text { comparison of manual needling with electrical stimulation and commonly used antiemetics. Anaesthesia } \\
\text { 1987; 42:1108-10 (note that metoclopramide group was not included in this trial, but the results of } \\
\text { other groups are the same). According to the authors, there were no side effects associated with } \\
\text { acupuncture groups but some patients complained of drowsiness following antiemetic drug } \\
\text { administration. For data analyses, manual acupuncture group was compared with cyclizine, and } \\
\text { electroacupuncture group was compared with metoclopramide. }\end{array}$ \\
\hline
\end{tabular}

Risk of bias

\begin{tabular}{l|l|l}
\hline Item & Authors' judgement & Description \\
\hline Adequate sequence generation? & Unclear & Insufficient information. \\
\hline Allocation concealment? & Unclear & Insufficient information. \\
\hline $\begin{array}{l}\text { Incomplete outcome data } \\
\text { addressed? All outcomes }\end{array}$ & Yes & No missing data reported for 155 patients analysed. \\
\hline Free of selective reporting? & Unclear & $\begin{array}{l}\text { No details about the use of rescue antiemetic in } \\
\text { anaesthetic protocol. The riisk of rescue antiemetic } \\
\text { drug not reported. }\end{array}$ \\
\hline Free of other bias? & $\begin{array}{l}\text { Demographic comparisons between groups were not } \\
\text { given. }\end{array}$ \\
\hline Blinding of patients? All outcomes & Unclear & Insufficient information. \\
\hline $\begin{array}{l}\text { Blinding of healthcare providers? } \\
\text { All outcomes }\end{array}$ & Unclear & Insufficient information. \\
\hline $\begin{array}{l}\text { Blinding of outcome assessor? All } \\
\text { outcomes }\end{array}$ & Yes & $\begin{array}{l}\text { "Patients were visited at } 1 \mathrm{~h} \text { and } 6 \mathrm{~h} \text { after operation by } \\
\text { treatment". }\end{array}$ \\
\hline Ferson whan of the preoperative
\end{tabular}

Fassoulaki 1993

\begin{tabular}{l|l} 
Methods & $\begin{array}{l}\text { Method of allocation concealment not given. Transcutaneous electrical nerve stimulator, active or } \\
\text { inactive, was covered with dark plastic bags. Outcome assessor was blinded to treatment allocation. }\end{array}$ \\
\hline Participants & $\begin{array}{l}106 \text { women undergoing abdominal hysterectomy. Three patients in the sham group were excluded } \\
\text { because they were given metoclopramide in the postoperative period for persistent vomiting (but this } \\
\text { data was included for risk of rescue antiemetic given analysis). }\end{array}$ \\
\hline Interventions & $\begin{array}{l}\text { Transcutaneous electrical nerve stimulation on the P6 acupoint was applied 30-45 min before induction } \\
\text { and continued for 6 hours postoperatively. } \\
\text { Sham group was treated the same way but with the electrical stimulator turned off. }\end{array}$ \\
\hline Outcomes & Vomiting $(0-2 \mathrm{~h})$ without antiemetic rescue, risk of rescue antiemetic (metoclopramide). \\
\hline Notes & $\begin{array}{l}\text { Potential bias if outcome assessor removed plastic bag covering the stimulator. Reported vomiting 2- } \\
4 \mathrm{~h}, 4-6 \mathrm{~h}, 6-8 \mathrm{~h} \text { intervals. No data on vomiting }(0-8 \mathrm{~h}) .\end{array}$ \\
\hline
\end{tabular}

Risk of bias

\begin{tabular}{l|l|l}
\hline Item & Authors' judgement & Description \\
\hline Adequate sequence generation? & Unclear & Insufficient information. \\
\hline Allocation concealment? & Unclear & Insufficient information. \\
\hline $\begin{array}{l}\text { Incomplete outcome data } \\
\text { addressed? All outcomes }\end{array}$ & No & $\begin{array}{l}\text { "Three patients, originally assigned to the control } \\
\text { groups, who received postoperatively metoclopramide } \\
\text { because of persistent vomiting were eliminated from } \\
\text { further vomiting evaluation and consequently from the } \\
\text { study". Comment: may introduce clinically relevant } \\
\text { bias in summary effect measure. }\end{array}$ \\
\hline
\end{tabular}




\begin{tabular}{l|l|l} 
Free of selective reporting? & No & Nausea and side effects were not reported. \\
\hline Free of other bias? & Yes & $\begin{array}{l}\text { Baseline characteristics were comparable. "The two } \\
\text { groups did not differ in age, body weight, duration of } \\
\text { anaesthesia, and duration of surgery (Table 1)". }\end{array}$ \\
\hline Blinding of patients? All outcomes & Yes & $\begin{array}{l}\text { "The stimulator, active or inactive, was covered with } \\
\text { dark plastic bags, not allowing distinction between } \\
\text { active and inactive stimulators". }\end{array}$ \\
\hline $\begin{array}{l}\text { Blinding of healthcare providers? } \\
\text { All outcomes }\end{array}$ & Unclear & Insufficient information. \\
\hline $\begin{array}{l}\text { Blinding of outcome assessor? All } \\
\text { outcomes }\end{array}$ & Yes & $\begin{array}{l}\text { Vomiting was assessed by "an independent observer } \\
\text { who was unaware of the patient randomization and of } \\
\text { TENS treatment". }\end{array}$ \\
\hline
\end{tabular}

Ferrara-Love 1996

Methods

Allocation was done by birth date with even numbered months and days assigned to the treatment group, odd months and days assigned to the sham acupressure group, and combinations of even/odd months and days assigned to the no treatment group. Recovery room nurses were blinded to patients with acupressure and sham acupressure wristbands.

\begin{tabular}{|c|c|c|}
\hline Participants & \multicolumn{2}{|c|}{$\begin{array}{l}136 \text { adults undergoing orthopaedic, general, plastic, and 'other' surgery. Forty-six patients excluded } \\
\text { after randomisation for failure to meet inclusion criteria. }\end{array}$} \\
\hline Interventions & \multicolumn{2}{|c|}{$\begin{array}{l}\text { Group 1: acupressure wristbands placed on P6 acupoint during surgery until hospital discharge. } \\
\text { Group 2: sham acupressure wristbands without studs placed on P6 acupoint during surgery until } \\
\text { hospital discharge. } \\
\text { Group 3: reference group had no acupressure treatment. }\end{array}$} \\
\hline Outcomes & \multicolumn{2}{|c|}{$\begin{array}{l}\text { Nausea in the operating room after surgery, risk of rescue antiemetic drugs in the operating room if } \\
\text { nausea persisted and/or emesis occurred. }\end{array}$} \\
\hline Notes & \multicolumn{2}{|c|}{ No treatment group excluded from data analysis. No cumulative outcome data. } \\
\hline \multicolumn{3}{|l|}{ Risk of bias } \\
\hline Item & Authors' judgement & Description \\
\hline Adequate sequence generation? & Unclear & Insufficient information. \\
\hline Allocation concealment? & No & $\begin{array}{l}\text { "Randomization was done by birth date with even } \\
\text { numbered months and days assigned to the treatment } \\
\text { group, odd months and days assigned to the placebo } \\
\text { group and combinations of even/odd months and days } \\
\text { assigned to the control group". }\end{array}$ \\
\hline $\begin{array}{l}\text { Incomplete outcome data } \\
\text { addressed? All outcomes }\end{array}$ & Yes & No missing data reported for the 90 patients analysed. \\
\hline Free of selective reporting? & No & $\begin{array}{l}\text { Risk of vomiting and side effects were not reported in } \\
\text { the results. }\end{array}$ \\
\hline Free of other bias? & Yes & $\begin{array}{l}\text { Baseline characteristics were comparable. "There were } \\
\text { no differences between groups in demographic and } \\
\text { perioperative variables" as tested using appropriate } \\
\text { univariate statistical tests. }\end{array}$ \\
\hline Blinding of patients? All outcomes & Yes & $\begin{array}{l}\text { Authors took adequate steps to make interventions } \\
\text { appear similar. }\end{array}$ \\
\hline $\begin{array}{l}\text { Blinding of healthcare providers? } \\
\text { All outcomes }\end{array}$ & Yes & PACU staff were blinded. \\
\hline $\begin{array}{l}\text { Blinding of outcome assessor? All } \\
\text { outcomes }\end{array}$ & Yes & $\begin{array}{l}\text { "Incidence of postoperative nausea and vomiting was } \\
\text { documented by the PACU staff who were blinded as to } \\
\text { treatment and placebo group". }\end{array}$ \\
\hline \multicolumn{3}{|l|}{ Gan 2004} \\
\hline Methods & \multicolumn{2}{|c|}{$\begin{array}{l}\text { Randomization by random number generator in a sealed envelope technique. To maintain patient } \\
\text { blinding, sham surface electrodes placed on P6 bilaterally but electrical stimulation unit not turned on. } \\
\text { Electrical stimulation unit screen was covered with an opaque tape in all groups so that clinicians, } \\
\text { research personnel, and patients were unaware if the unit was on or off. Study medication prepared by } \\
\text { pharmacists, not involved in study. Postoperative data collected by research nurse not involved in } \\
\text { management of patients. }\end{array}$} \\
\hline
\end{tabular}




\begin{tabular}{l|l} 
Participants & $\begin{array}{l}77 \text { patients undergoing major breast surgery. Exclusion: pregnancy, using permanent cardiac } \\
\text { pacemaker, previous experience of acupuncture therapies, received any antiemetic medication or had } \\
\text { nausea, vomiting or retching within 24 hours of surgery. Two patients withdrew from study. }\end{array}$ \\
\hline Interventions & $\begin{array}{l}\text { Group 1: ondansetron } 4 \mathrm{mg} \text { IV given at induction of anaesthesia and sham electro-acupoint stimulation } \\
\text { at P6 acupoints (30 to } 60 \text { min before induction and continued to the end of surgery). } \\
\text { Group 2: electro-acupoint stimulation at P6 bilaterally (30 to 60 min before induction and continued to } \\
\text { the end of surgery) and saline IV given at induction of anaesthesia. } \\
\text { Group 3: sham electro-acupoint stimulation at P6 bilaterally (30 to } 60 \text { min before induction and } \\
\text { continued to the end of surgery) and saline IV given at induction of anaesthesia. }\end{array}$ \\
\hline Outcomes & Nausea (0-2h), vomiting (0-2h), risk of rescue antiemetic drug, adverse effects. \\
\hline Notes & $\begin{array}{l}\text { Rescue antiemetic was dexamethasone } 8 \mathrm{mg} \text { IV when patient's nausea score }>5 \text { out of } 10 \text { for } 15 \text { min or } \\
\text { longer, } 2 \text { emetic episodes within } 15 \text { min, or at patient's request. No redness residue on acupoint site in } \\
\text { any groups. }\end{array}$ \\
\hline
\end{tabular}

\begin{tabular}{|c|c|c|}
\hline \multicolumn{3}{|l|}{ Risk of bias } \\
\hline Item & Authors' judgement & Description \\
\hline Adequate sequence generation? & Yes & $\begin{array}{l}\text { "Randomization was achieved using a random number } \\
\text { generator..". }\end{array}$ \\
\hline Allocation concealment? & Yes & $\begin{array}{l}\text { “...In a sealed envelope technique". "Study drugs were } \\
\text { prepared by the pharmacists not directly involved in the } \\
\text { study...". Comments: the authors appeared to take steps } \\
\text { to minimize inadequate allocation concealment. }\end{array}$ \\
\hline $\begin{array}{l}\text { Incomplete outcome data } \\
\text { addressed? All outcomes }\end{array}$ & Yes & $\begin{array}{l}\text { Reasons for withdrawals were given. No missing data } \\
\text { reported for the } 75 \text { patients analysed. }\end{array}$ \\
\hline Free of selective reporting? & Yes & All expected outcomes reported. \\
\hline Free of other bias? & Yes & $\begin{array}{l}\text { Baseline characteristics were comparable. "There was } \\
\text { no difference in patient demographics among the } \\
\text { groups (Table 1)". }\end{array}$ \\
\hline Blinding of patients? All outcomes & Yes & $\begin{array}{l}\text { "All patients were also told that the device produced an } \\
\text { electrical current that they may or may not feel. The } \\
\text { screen on the unit (measuring } 4 \times 2 \mathrm{~cm} \text { ) was covered } \\
\text { with an opaque tape in all groups so that the clinicians } \\
\text { and research personnel were unaware if the unit was on } \\
\text { or off". }\end{array}$ \\
\hline $\begin{array}{l}\text { Blinding of healthcare providers? } \\
\text { All outcomes }\end{array}$ & Yes & $\begin{array}{l}\text { "All patients were also told that the device produced an } \\
\text { electrical current that they may or may not feel. The } \\
\text { screen on the unit (measuring } 4 \times 2 \mathrm{~cm} \text { ) was covered } \\
\text { with an opaque tape in all groups so that the clinicians } \\
\text { and research personnel were unaware if the unit was on } \\
\text { or off". }\end{array}$ \\
\hline $\begin{array}{l}\text { Blinding of outcome assessor? All } \\
\text { outcomes }\end{array}$ & Yes & $\begin{array}{l}\text { "Postoperative data were collected by a separate } \\
\text { research nurse not involved in the preoperative or } \\
\text { intraoperative management of patients". }\end{array}$ \\
\hline \multicolumn{3}{|l|}{ Gieron 1993} \\
\hline Methods & \multicolumn{2}{|c|}{$\begin{array}{l}\text { Method of allocation concealment not given. Outcome assessor knew what treatment group the patient } \\
\text { belonged to. }\end{array}$} \\
\hline Participants & \multicolumn{2}{|c|}{90 Women undergoing gynaecological operations (6-8h). } \\
\hline Interventions & \multicolumn{2}{|c|}{$\begin{array}{l}\text { Group 1: acupressure was carried out by fastening small metal bullets at the P6 acupoint to each wrist } \\
\text { by an elastic bandage on the morning of the operation and left on for } 24 \mathrm{~h} \text {. } \\
\text { Group 2: sham acupressure carried out by applying elastic bandage to P6 acupoint on the morning of } \\
\text { the operation and left on for } 24 \mathrm{~h} \text {. } \\
\text { Group 3: no treatment. }\end{array}$} \\
\hline Outcomes & \multicolumn{2}{|c|}{ Nausea $(0-6 \mathrm{~h})$, vomiting $(0-6 \mathrm{~h})$, risk of rescue antiemetic (metoclopramide). } \\
\hline Notes & \multicolumn{2}{|c|}{$\begin{array}{l}\text { No treatment data were excluded from analysis. Also reported separate incidences of nausea and } \\
\text { vomiting }(0-1 \mathrm{~h}) \text { and }(6-24 \mathrm{~h}) \text {. No side effects identified in the trial. }\end{array}$} \\
\hline \multicolumn{3}{|l|}{ Risk of bias } \\
\hline Item & Authors' judgement & Description \\
\hline
\end{tabular}




\begin{tabular}{|c|c|c|}
\hline Adequate sequence generation? & Unclear & Insufficient information. \\
\hline Allocation concealment? & Unclear & Insufficient information. \\
\hline $\begin{array}{l}\text { Incomplete outcome data } \\
\text { addressed? All outcomes }\end{array}$ & Yes & No missing data reported for 90 patients analysed. \\
\hline Free of selective reporting? & Yes & All expected outcomes were reported. \\
\hline Free of other bias? & Yes & $\begin{array}{l}\text { Baseline characteristics were comparable. "The } \\
\text { anthropometric data, the duration of surgery and the } \\
\text { amount of postoperative analgesia were comparable } \\
\text { between the three groups". }\end{array}$ \\
\hline Blinding of patients? All outcomes & Yes & $\begin{array}{l}\text { Authors took adequate steps to make interventions } \\
\text { appear similar. }\end{array}$ \\
\hline $\begin{array}{l}\text { Blinding of healthcare providers? } \\
\text { All outcomes }\end{array}$ & Unclear & Insufficient information. \\
\hline $\begin{array}{l}\text { Blinding of outcome assessor? All } \\
\text { outcomes }\end{array}$ & No & The outcome assessor was not blinded. \\
\hline \multicolumn{3}{|l|}{ Habib 2006} \\
\hline Methods & \multicolumn{2}{|c|}{$\begin{array}{l}\text { Method of allocation concealment unclear. For blinding, the transcutaneous acupoint electrical } \\
\text { stimulation was covered with opaque gauze that was taped to the wrist. Outcome assessor blinded. }\end{array}$} \\
\hline Participants & \multicolumn{2}{|c|}{$\begin{array}{l}94 \text { Women undergoing Caesarean delivery under spinal anaesthesia. Exclusion: previous experience of } \\
\text { acupuncture or acu-stimulation, had experienced vomiting or retching within } 24 \mathrm{~h} \text { before surgery, had } \\
\text { taken on antiemetic or a glucocorticoid within } 24 \mathrm{~h} \text { before surgery, or had an implanted pacemaker or } \\
\text { defibrillator device. Three patients withdrew from study because of protocol violations. }\end{array}$} \\
\hline Interventions & \multicolumn{2}{|c|}{$\begin{array}{l}\text { Transcutaneous acupoint electrical stimulation device on P6 acupoint of the dominant hand } 30 \text { to } 60 \\
\text { min before surgery. Patients asked to wear wristband for } 24 \mathrm{~h} \text { after surgery. Sham transcutaneous } \\
\text { acupoint electrical stimulation device on dorsum of wrist of the dominant hand } 30 \text { to } 60 \text { min before } \\
\text { surgery. Patients asked to wear wristband for } 24 \mathrm{~h} \text { after surgery. }\end{array}$} \\
\hline Outcomes & \multicolumn{2}{|c|}{ Postoperative nausea $(0-24 \mathrm{~h})$, postoperative vomiting $(0-24 \mathrm{~h})$, risk of rescue antiemetic. } \\
\hline Notes & \multicolumn{2}{|c|}{$\begin{array}{l}\text { Intraoperative nausea and vomiting data reported in the paper. Rescue antiemetic was ondansetron } 4 \mathrm{mg} \\
\text { IV if nausea score was } 6 \text { or more, or at patient's request. }\end{array}$} \\
\hline \multicolumn{3}{|l|}{ Risk of bias } \\
\hline Item & Authors' judgement & Description \\
\hline Adequate sequence generation? & Unclear & Insufficent information. \\
\hline Allocation concealment? & Unclear & Insufficient information. \\
\hline $\begin{array}{l}\text { Incomplete outcome data } \\
\text { addressed? All outcomes }\end{array}$ & Yes & $\begin{array}{l}\text { Reasons for withdrawals given. No missing data } \\
\text { reported for } 91 \text { patients analysed. }\end{array}$ \\
\hline Free of selective reporting? & No & Side effects not reported \\
\hline Free of other bias? & Yes & $\begin{array}{l}\text { Baseline characteristics were comparable. "The two } \\
\text { groups were similar with respect to demographics, } \\
\text { parity, history of PONV or motion sickness, smoking } \\
\text { status, duration of surgery, blood loss, intraoperative } \\
\text { fluids, intraoperative IV fentanyl, intraoperative IV } \\
\text { ephedrine, treatment for pruritus, and consumption of } \\
\text { oxycodone/acetaminophen tablets (Table 1)". }\end{array}$ \\
\hline Blinding of patients? All outcomes & Yes & $\begin{array}{l}\text { Authors took adequate steps to make interventions } \\
\text { appear similar. "For blinding, the ReliefBand was } \\
\text { covered with opaque gauze that was taped to the wrist". }\end{array}$ \\
\hline $\begin{array}{l}\text { Blinding of healthcare providers? } \\
\text { All outcomes }\end{array}$ & Unclear & Insufficient information. \\
\hline $\begin{array}{l}\text { Blinding of outcome assessor? All } \\
\text { outcomes }\end{array}$ & Yes & $\begin{array}{l}\text { "A separate researcher who was unaware of the } \\
\text { patient's randomisation collected that data...". }\end{array}$ \\
\hline \multicolumn{3}{|l|}{ Harmon 1999} \\
\hline Methods & \multicolumn{2}{|c|}{$\begin{array}{l}\text { Randomization was conducted by computer and the code was sealed (not opaque) until arrival of patient } \\
\text { in the operating theatre. Outcome assessor was blinded to treatment groups. }\end{array}$} \\
\hline
\end{tabular}




\begin{tabular}{l|l} 
Participants & $\begin{array}{l}\text { 104 Women undergoing laparoscopy and dye investigation. Exclusions: obesity, diabetes mellitus, and } \\
\text { previous history of PONV. }\end{array}$ \\
\hline Interventions & $\begin{array}{l}\text { Acupressure on P6 acupoint of right wrist, applied immediately before induction for } 20 \text { min, removed } \\
\text { before end of surgery. } \\
\text { Placebo acupressure on non-acupoint site, applied before induction for } 20 \text { min and removed before end } \\
\text { of surgery. }\end{array}$ \\
\hline Outcomes & Nausea $(0-24 \mathrm{~h})$, vomiting $(0-24 \mathrm{~h})$, risk of rescue antiemetic drugs. \\
\hline Notes & $\begin{array}{l}\text { Rescue antiemetic was ondansetron } 4 \mathrm{mg} \text { IV and prochlorperazine } 12.5 \mathrm{mg} \text { IM. No side effects in either } \\
\text { group noted. Some patients did not have outcome data. }\end{array}$ \\
\hline
\end{tabular}

\section{Risk of bias}

\begin{tabular}{|c|c|c|}
\hline Item & Authors' judgement & Description \\
\hline Adequate sequence generation? & Yes & "Randomization was conducted by computer..". \\
\hline Allocation concealment? & Unclear & $\begin{array}{l}\text { "...And the code was sealed until arrival of the patient } \\
\text { in the operating theatre". Comment: not sure whether } \\
\text { envelopes were sequentially numbered and opaque. }\end{array}$ \\
\hline $\begin{array}{l}\text { Incomplete outcome data } \\
\text { addressed? All outcomes }\end{array}$ & No & $\begin{array}{l}\text { In acupressure group }(\mathrm{n}=52) \text {, missing nausea and } \\
\text { vomiting data in } 8 \text { and } 5 \text { patients respectively. In sham } \\
\text { group }(\mathrm{n}=52) \text {, missing nausea and vomiting data in } 13 \\
\text { and } 5 \text { patients respectively. }\end{array}$ \\
\hline Free of selective reporting? & Yes & All expected outcomes reported. \\
\hline Free of other bias? & Yes & $\begin{array}{l}\text { Baseline characteristics were comparable. "The groups } \\
\text { were comparable in age, weight and duration of } \\
\text { surgical procedure (Table 1)". }\end{array}$ \\
\hline Blinding of patients? All outcomes & Yes & $\begin{array}{l}\text { "Both patients and nurses were unaware of patient } \\
\text { group allocation". }\end{array}$ \\
\hline $\begin{array}{l}\text { Blinding of healthcare providers? } \\
\text { All outcomes }\end{array}$ & Yes & $\begin{array}{l}\text { "Both patients and nurses were unaware of patient } \\
\text { group allocation". }\end{array}$ \\
\hline $\begin{array}{l}\text { Blinding of outcome assessor? All } \\
\text { outcomes }\end{array}$ & Yes & $\begin{array}{l}\text { "..An anaesthetist blinded to the therapy registered } \\
\text { whether nausea, retching or vomiting had occurred". }\end{array}$ \\
\hline \multicolumn{3}{|l|}{ Harmon 2000} \\
\hline Methods & \multicolumn{2}{|c|}{$\begin{array}{l}\text { Method of allocation concealment was not given. Acupressure wristbands and placebo acupressure } \\
\text { wristbands were covered with surgical drapes to prevent anaesthetist from identifying which group the } \\
\text { patient was allocated to. Patients might have guessed which group they were in as there was no attempt } \\
\text { to conceal the wristband. Authors claimed that the outcome assessor was blinded to treatment group. }\end{array}$} \\
\hline Participants & \multicolumn{2}{|c|}{$\begin{array}{l}94 \text { Healthy women ( } 18 \text { to } 40 \text { years) undergoing elective Caesarean section. Excluded: previous history } \\
\text { of PONV, nausea and vomiting in previous } 24 \text { hours, obesity (body mass index }>35 \text { ), diabetes mellitus, } \\
\text { or previous experience of acupuncture or acupressure. }\end{array}$} \\
\hline Interventions & \multicolumn{2}{|c|}{$\begin{array}{l}\text { Acupressure on P6 acupoint on right wrist, applied } 5 \text { min before administration of spinal anaesthesia, } \\
\text { removed just before assessment } 6 \text { hours after discharge to the ward. } \\
\text { Placebo acupressure on non-acupoint site, applied } 5 \text { min before administration of spinal anaesthesia, } \\
\text { removed just before assessment } 6 \text { hours after discharge to the ward. }\end{array}$} \\
\hline Outcomes & \multicolumn{2}{|c|}{ Nausea (0-24h), vomiting $(0-24 h)$. } \\
\hline Notes & \multicolumn{2}{|c|}{$\begin{array}{l}\text { Reported separate incidence of intraoperative nausea and vomiting. Rescue antiemetic was ondansetron } \\
4 \mathrm{mg} \text { IV during operations, or cyclizine } 50 \mathrm{mg} \text { IM } 8 \text { hourly after operations. Rescue antiemetic use } \\
\text { reported as mean dose (no data for risk of rescue cyclizine use). Side effect of acupressure bands was } \\
\text { "some localized discomfort in a small number of women". }\end{array}$} \\
\hline \multicolumn{3}{|l|}{ Risk of bias } \\
\hline Item & Authors' judgement & Description \\
\hline Adequate sequence generation? & Unclear & Insufficient information. \\
\hline Allocation concealment? & Unclear & Insufficient information. \\
\hline $\begin{array}{l}\text { Incomplete outcome data } \\
\text { addressed? All outcomes }\end{array}$ & Yes & $\begin{array}{l}\text { Reasons for withdrawals were given. No missing data } \\
\text { reported for } 94 \text { patients analysed. }\end{array}$ \\
\hline
\end{tabular}




\begin{tabular}{l|l|l} 
Free of selective reporting? & No & $\begin{array}{l}\text { Risk of rescue cyclizine not reported separately for } \\
\text { nausea and vomiting outcomes. }\end{array}$ \\
\hline Free of other bias? & Yes & $\begin{array}{l}\text { Baseline characteristics were comparable. "The groups } \\
\text { were comparable with respect to age, weight, height } \\
\text { and bupivacaine dose (Table 1)". }\end{array}$ \\
\hline Blinding of patients? All outcomes & Yes & $\begin{array}{l}\text { Authors took adequate steps to make interventions } \\
\text { appear similar. }\end{array}$ \\
\hline $\begin{array}{l}\text { Blinding of healthcare providers? } \\
\text { All outcomes }\end{array}$ & Yes & $\begin{array}{l}\text { "Bands were not visible to the assessing anaesthetist } \\
\text { during operations, as patients' arms were covered with } \\
\text { surgical drapes". }\end{array}$ \\
\hline $\begin{array}{l}\text { Blinding of outcome assessor? All } \\
\text { outcomes }\end{array}$ & Yes & $\begin{array}{l}\text { "After 6 and 24h, an anaesthetist blinded to the therapy } \\
\text { noted whether nausea, retching or vomiting had } \\
\text { occurred". }\end{array}$ \\
\hline Ho 1989 & &
\end{tabular}

\begin{tabular}{l|l}
\hline Methods & $\begin{array}{l}\text { Method of allocation concealment not given. No details about whether the outcome assessor was } \\
\text { blinded to treatment groups or not. }\end{array}$ \\
\hline Participants & 100 Women undergoing laparoscopy. \\
\hline Interventions & $\begin{array}{l}\text { Group 1: electro-acupuncture applied at P6 acupoint on right wrist for 15 min in the recovery room. } \\
\text { Group 2: transcutaneous electrical nerve stimulation at P6 acupoint on right wrist for 15 min in the } \\
\text { recovery room. } \\
\text { Group 3: antiemetic group was given prochlorperazine } 5 \mathrm{mg} \text { IV. } \\
\text { Group 4: no treatment. }\end{array}$ \\
\hline Outcomes & Vomiting (0-3h), side effects of treatment groups. \\
\hline Notes & $\begin{array}{l}\text { Reference group received no treatment and was not included in data analysis. Groups 1 and 2 were } \\
\text { combined for data analysis. Side effect of electro-acupuncture were sleepiness and feeling tired. }\end{array}$ \\
\hline Risk of bias &
\end{tabular}

\begin{tabular}{|c|c|c|}
\hline Item & Authors' judgement & Description \\
\hline Adequate sequence generation? & Unclear & Insufficient information. \\
\hline Allocation concealment? & Unclear & Insufficient information. \\
\hline $\begin{array}{l}\text { Incomplete outcome data } \\
\text { addressed? All outcomes }\end{array}$ & Yes & $\begin{array}{l}\text { No missing data was reported for the } 100 \text { patients } \\
\text { analysed. }\end{array}$ \\
\hline Free of selective reporting? & No & $\begin{array}{l}\text { Only vomiting was reported. Authors should have } \\
\text { assessed nausea in women and the risk of rescue } \\
\text { antiemetic drugs. }\end{array}$ \\
\hline Free of other bias? & Yes & $\begin{array}{l}\text { Baseline characteristics were comparable. "The age, } \\
\text { weight, and duration of anaesthesia did not differ } \\
\text { significantly among the groups (Table 1)". }\end{array}$ \\
\hline Blinding of patients? All outcomes & Unclear & Insufficient information. \\
\hline $\begin{array}{l}\text { Blinding of healthcare providers? } \\
\text { All outcomes }\end{array}$ & Unclear & Insufficient information. \\
\hline $\begin{array}{l}\text { Blinding of outcome assessor? All } \\
\text { outcomes }\end{array}$ & Unclear & Insufficient information. \\
\hline \multicolumn{3}{|l|}{ Ho 1996} \\
\hline Methods & \multicolumn{2}{|c|}{$\begin{array}{l}\text { Randomization conducted by computer, with each code sealed in an envelope (not opaque) to be openec } \\
\text { before induction of spinal anaesthesia. Outcome assessor was blinded to treatment groups. }\end{array}$} \\
\hline Participants & \multicolumn{2}{|c|}{$\begin{array}{l}60 \text { Women receiving epidural morphine for post-Caesarean section pain relief. Excluded: previous } \\
\text { carpal tunnel syndrome, or those who had experienced nausea or vomiting within } 24 \mathrm{~h} \text { before Caesarean } \\
\text { section. }\end{array}$} \\
\hline Interventions & \multicolumn{2}{|c|}{$\begin{array}{l}\text { Group 1: acupressure wristbands on P6 acupoint of both wrists before administration of spinal } \\
\text { anaesthesia. Worn for } 48 \text { hours. } \\
\text { Group 2: sham acupressure wristbands on both wrists but plastic button was blunted in order not to } \\
\text { exert pressure on P6 acupoint. Worn for } 48 \text { hours. }\end{array}$} \\
\hline
\end{tabular}




\begin{tabular}{|c|c|c|}
\hline Outcomes & \multicolumn{2}{|c|}{$\begin{array}{l}\text { Nausea }(0-48 h) \text {, vomiting }(0-48 h) \text {, risk of rescue antiemetic drug, side effects of acupressure } \\
\text { wristbands. }\end{array}$} \\
\hline Notes & \multicolumn{2}{|c|}{ Rescue antiemetic was metoclopramide. No side effects were noted. } \\
\hline \multicolumn{3}{|l|}{ Risk of bias } \\
\hline Item & Authors' judgement & Description \\
\hline Adequate sequence generation? & Yes & "Randomization was conducted by computer..". \\
\hline Allocation concealment? & Unclear & $\begin{array}{l}\text { “...With each code sealed in an envelope to be opened } \\
\text { upon the parturient's arrival in the operating room". } \\
\text { Comment: not sure if envelopes were sequentially } \\
\text { numbered and opaque. }\end{array}$ \\
\hline $\begin{array}{l}\text { Incomplete outcome data } \\
\text { addressed? All outcomes }\end{array}$ & Yes & $\begin{array}{l}\text { "All parturients completed the trial and tolerated the } \\
\text { bands well". }\end{array}$ \\
\hline Free of selective reporting? & Yes & All expected outcomes reported. \\
\hline Free of other bias? & Yes & $\begin{array}{l}\text { Baseline characteristics were comparable. "There were } \\
\text { no statistically significant difference with respect to } \\
\text { age, weight, height, duration of operation, } \\
\text { intraoperative blood loss, duration of pain relief, total } \\
\text { epidural morphine dosage, percentage of parturients } \\
\text { requiring additional analgesics and total time spent } \\
\text { wearing bands between the two groups". }\end{array}$ \\
\hline Blinding of patients? All outcomes & Yes & $\begin{array}{l}\text { Authors took adequate steps to make interventions } \\
\text { appear similar. }\end{array}$ \\
\hline $\begin{array}{l}\text { Blinding of healthcare providers? } \\
\text { All outcomes }\end{array}$ & Unclear & Insufficient information. \\
\hline $\begin{array}{l}\text { Blinding of outcome assessor? All } \\
\text { outcomes }\end{array}$ & Yes & $\begin{array}{l}\text { "An independent anaesthesiologist blinded to the } \\
\text { parturient groups followed up all parturients". }\end{array}$ \\
\hline \multicolumn{3}{|l|}{ Klein 2004} \\
\hline Methods & \multicolumn{2}{|c|}{$\begin{array}{l}\text { Patients randomized by computer-generated random number tables to either acupressure or sham } \\
\text { groups. Both groups had acupressure bands covered by a soft cotton roll to ensure blinding. } \\
\text { Anaesthetist caring for the patient was not aware of the group allocation. Outcome assessor blinded to } \\
\text { treatment allocation. }\end{array}$} \\
\hline Participants & \multicolumn{2}{|c|}{$\begin{array}{l}152 \text { Patients undergoing coronary artery bypass graft or valvular surgery. Exclusion: past history of } \\
\text { hiatus hernia, heartburn, or previous gastric surgery, morbid obesity, taking antiemetic medications, H2 } \\
\text { receptor antagonist, or proton pump inhibitors. No details about withdrawals or loss to follow up. }\end{array}$} \\
\hline Interventions & \multicolumn{2}{|c|}{$\begin{array}{l}\text { Acupressure wristbands on P6 acupoint on both wrists before induction of anaesthesia, removed } 24 \mathrm{~h} \\
\text { after extubation. } \\
\text { Sham acupressure wristbands on P6 acupoint of both wrists before induction of anaesthesia, removed } \\
24 \mathrm{~h} \text { after extubation. Sham group had band without a bead placed on P6 acupoint. }\end{array}$} \\
\hline Outcomes & \multicolumn{2}{|c|}{ Nausea $(0-24 h)$, vomiting $(0-24 h)$, risk of rescue antiemetic drug, risk of adverse effects. } \\
\hline Notes & \multicolumn{2}{|c|}{$\begin{array}{l}\text { Rescue antiemetic was dimenhydrinate } 50 \mathrm{mg} \text { IV for patients who reported moderate or severe nausea, } \\
\text { or who experienced retching or vomiting. No significant adverse effects reported in either group. }\end{array}$} \\
\hline \multicolumn{3}{|l|}{ Risk of bias } \\
\hline Item & Authors' judgement & Description \\
\hline Adequate sequence generation? & Yes & $\begin{array}{l}\text { "Patients were randomized by computer-generated } \\
\text { random number tables to either acupressure or placebo } \\
\text { control groups". }\end{array}$ \\
\hline Allocation concealment? & Unclear & Insufficient information. \\
\hline $\begin{array}{l}\text { Incomplete outcome data } \\
\text { addressed? All outcomes }\end{array}$ & Yes & No missing data reported for the 152 patients analysed. \\
\hline Free of selective reporting? & Yes & Reported all expected outcomes. \\
\hline Free of other bias? & Yes & $\begin{array}{l}\text { Baseline characteristics were comparable. "There were } \\
\text { no differences between the } 2 \text { groups with regard to } \\
\text { demographic data and surgical characteristics (Table } \\
\text { 1)". }\end{array}$ \\
\hline
\end{tabular}




\begin{tabular}{l|l|l} 
Blinding of patients? All outcomes & Yes & $\begin{array}{l}\text { Authors took adequate steps to make interventions } \\
\text { appear similar. }\end{array}$ \\
\hline $\begin{array}{l}\text { Blinding of healthcare providers? } \\
\text { All outcomes }\end{array}$ & Yes & $\begin{array}{l}\text { "The anaesthesiologist caring for the patient was not } \\
\text { aware of group allocation". }\end{array}$ \\
\hline $\begin{array}{l}\text { Blinding of outcome assessor? All } \\
\text { outcomes }\end{array}$ & Yes & $\begin{array}{l}\text { "All patients were assessed for nausea and vomiting by } \\
\text { nursing staff in the intensive care unit, who were } \\
\text { unaware of treatment allocation". }\end{array}$ \\
\hline Lewis 1991 &
\end{tabular}

\begin{tabular}{|c|c|c|}
\hline Methods & \multicolumn{2}{|c|}{$\begin{array}{l}\text { Method of allocation concealment was not given. Outcome assessor was blinded. Acupressure } \\
\text { wristbands were worn for approximately } 4 \text { hours. }\end{array}$} \\
\hline Participants & \multicolumn{2}{|c|}{$\begin{array}{l}66 \text { Children undergoing strabismus correction surgery. Excluded: children with anatomical or } \\
\text { neurological abnormalities of the upper limbs. Two children lost to follow up. }\end{array}$} \\
\hline Interventions & \multicolumn{2}{|c|}{$\begin{array}{l}\text { Group 1: acupressure wristbands placed on P6 acupoints } 1 \text { hour before surgery and worn until discharge } \\
\text { from hospital. } \\
\text { Group 2: sham acupressure wristbands without studs placed on P6 acupoints } 1 \text { hour before surgery and } \\
\text { worn until discharge from hospital. }\end{array}$} \\
\hline Outcomes & \multicolumn{2}{|c|}{ Vomiting $(0-24 \mathrm{~h})$, risk of rescue antiemetic drug, side effects. } \\
\hline Notes & \multicolumn{2}{|c|}{$\begin{array}{l}\text { Both types of wristbands were identical unless turned inside out. Rescue antiemetic was droperidol } 0.02 \\
\mathrm{mg} / \mathrm{kg} \text { IV for vomiting. No side effects reported. }\end{array}$} \\
\hline \multicolumn{3}{|l|}{ Risk of bias } \\
\hline Item & Authors' judgement & Description \\
\hline Adequate sequence generation? & Unclear & Insufficient information. \\
\hline Allocation concealment? & Unclear & Insufficient information. \\
\hline $\begin{array}{l}\text { Incomplete outcome data } \\
\text { addressed? All outcomes }\end{array}$ & Yes & $\begin{array}{l}\text { Two patients in acupressure group had incomplete data. } \\
\text { Comment: unlikely to have a clinically relevant impact } \\
\text { on summary estimate. }\end{array}$ \\
\hline Free of selective reporting? & No & $\begin{array}{l}\text { Although nausea was an outcome collected in the } \\
\text { methods section it was not reported in the results } \\
\text { because nausea may be difficult to assess in children. }\end{array}$ \\
\hline Free of other bias? & Yes & $\begin{array}{l}\text { Baseline characteristics were comparable. "There were } \\
\text { no significant differences between the two groups in } \\
\text { their patient characteristics (Table 1)". }\end{array}$ \\
\hline Blinding of patients? All outcomes & Yes & $\begin{array}{l}\text { Authors took adequate steps to make interventions } \\
\text { appear similar. }\end{array}$ \\
\hline $\begin{array}{l}\text { Blinding of healthcare providers? } \\
\text { All outcomes }\end{array}$ & Yes & The anaesthetic staff were blinded. \\
\hline $\begin{array}{l}\text { Blinding of outcome assessor? All } \\
\text { outcomes }\end{array}$ & Yes & $\begin{array}{l}\text { "A second blinded investigator recorded all other } \\
\text { perioperative data, including the incidence of } \\
\text { postoperative nausea and vomiting in the recovery } \\
\text { areas". }\end{array}$ \\
\hline
\end{tabular}

Liu 2008

\begin{tabular}{l|l} 
Methods & Method of allocation concealment not given. Anaesthetist and the outcome assessor were blinded. \\
\hline Participants & $\begin{array}{l}\text { 96 Patients undergoing laparoscopic cholecystectomy who were aged 18 to 60 years. Exclusions: } \\
\text { pregnancy, women experiencing menstrual symptoms, patients with permanent cardiac pace-maker, } \\
\text { previous experience with acupuncture therapies before surgery, received antiemetics or experienced } \\
\text { nausea, vomiting, or retching within 24 h of surgery. No patients withdrew from study. }\end{array}$ \\
\hline Interventions & $\begin{array}{l}\text { Group 1: transcutaneous electro-acupoint stimulation using a peripheral nerve stimulator at P6 (2-100 } \\
\text { Hz, 50 ms, 0.5-4mA) applied 30 to } 60 \text { min before induction of anaesthesia, and continued to the end of } \\
\text { surgery. } \\
\text { Group 2: inactive device with similar electrode for transcutaneous electro-acupoint stimulation using a } \\
\text { peripheral nerve stimulator at P6 applied 30 to } 60 \text { min before induction of anaesthesia, and continued to } \\
\text { the end of surgery. }\end{array}$ \\
\hline Outcomes & $\begin{array}{l}\text { Nausea (0-24h), vomiting (0-24h), risk of rescue antiemetic drug }(0-24 \mathrm{~h}), \text { adverse effects of } \\
\text { transcutaneous electro-acupoint stimulation. }\end{array}$ \\
\hline
\end{tabular}


Rescue antiemetic drug was ondansetron $4 \mathrm{mg}$ IV, to patients who had a nausea score of more than 5 on a 10 point scale, vomited twice within 15 min, or at the patient's request. $\mathrm{P} 6$ acupoint stimulation was associated with a reduction in the risk of severe nausea (Group 1: 2/48 versus Group 2: 14/48). No redness, swelling, itching, and pain, or other relevant complications at P6 acupoint in the two groups.

\begin{tabular}{|c|c|c|}
\hline \multicolumn{3}{|l|}{ Risk of bias } \\
\hline Item & Authors' judgement & Description \\
\hline Adequate sequence generation? & Yes & $\begin{array}{l}\text { "Patients were randomized into two groups of } 48 \text { in } \\
\text { each using a table of random numbers". }\end{array}$ \\
\hline Allocation concealment? & Unclear & Insufficient information. \\
\hline $\begin{array}{l}\text { Incomplete outcome data } \\
\text { addressed? All outcomes }\end{array}$ & Yes & "All 96 patients completed the study". \\
\hline Free of selective reporting? & Yes & All expected outcomes reported. \\
\hline Free of other bias? & Yes & $\begin{array}{l}\text { Baseline characteristics were comparable. "As shown } \\
\text { in Table } 1 \text { and Table } 2 \text {, the patients' gender, age, } \\
\text { weight, ASA physical status, previous PONV history, } \\
\text { duration of surgery or anaesthesia, transfusion amount, } \\
\text { operative procedure and doses of opioids in the two } \\
\text { groups were not significantly different". }\end{array}$ \\
\hline Blinding of patients? All outcomes & Yes & $\begin{array}{l}\text { Authors took adequate steps to make interventions } \\
\text { appear similar. }\end{array}$ \\
\hline $\begin{array}{l}\text { Blinding of healthcare providers? } \\
\text { All outcomes }\end{array}$ & Yes & $\begin{array}{l}\text { "The anesthesiologists and care providers were blinded } \\
\text { to the study group". }\end{array}$ \\
\hline $\begin{array}{l}\text { Blinding of outcome assessor? All } \\
\text { outcomes }\end{array}$ & Yes & $\begin{array}{l}\text { "Postoperative data were collected by a separate } \\
\text { research nurse who was not aware of the preoperative } \\
\text { or perioperative management of patients". }\end{array}$ \\
\hline \multicolumn{3}{|l|}{ Misra 2005} \\
\hline Methods & \multicolumn{2}{|c|}{$\begin{array}{l}\text { Method of allocation concealment was not given. Subjects were randomly assigned to groups using } \\
\text { computer-generated random number table. Patient, anaesthetist, and the outcome assessor were blinded. }\end{array}$} \\
\hline Participants & \multicolumn{2}{|c|}{$\begin{array}{l}123 \text { Adults (18-52y) undergoing middle ear surgery. Exclusion: pregnancy, obesity, diabetes mellitus, } \\
\text { impaired renal or liver functions; patients who had taken } \mathrm{H} 2 \text { antagonists, antiemetics, or psychoactive } \\
\text { medication; or had nausea, retching, or vomiting within } 48 \mathrm{~h} \text { before surgery. Three patients withdrew } \\
\text { because: they required administration of dexamethasone }(\mathrm{n}=2) \text {, and facial nerve injury }(\mathrm{n}=1) \text {. }\end{array}$} \\
\hline Interventions & \multicolumn{2}{|c|}{$\begin{array}{l}\text { Group 1: sham plaster } 1 \mathrm{~cm} \times 1 \mathrm{~cm} \text { patch affixed to } \mathrm{P} 6 \text { acupoint on both forearms } 30 \mathrm{~min} \text { before } \\
\text { induction of anaesthesia and normal saline IV at the end of surgery. Plasters removed } 6 \mathrm{~h} \text { after surgery. } \\
\text { Group 2: capsicum plaster containing capsicum oleoresin } 1 \% \mathrm{w} / \mathrm{w} 1 \mathrm{~cm} \times 1 \mathrm{~cm} \text { patch affixed to P6 } \\
\text { acupoint on both forearms } 30 \mathrm{~min} \text { before induction of anaesthesia and normal saline IV at the end of } \\
\text { surgery. Plasters removed } 6 \mathrm{~h} \text { after surgery. } \\
\text { Group 3: sham plaster } 1 \mathrm{~cm} \times 1 \mathrm{~cm} \text { patch affixed to P6 acupoint on both forearms } 30 \mathrm{~min} \text { before } \\
\text { induction of anaesthesia and ondansetron } 4 \mathrm{mg} \text { IV at the end of surgery. Plasters removed } 6 \mathrm{~h} \text { after } \\
\text { surgery. }\end{array}$} \\
\hline Outcomes & \multicolumn{2}{|c|}{ Nausea $(0-24 \mathrm{~h})$, vomiting $(0-24 \mathrm{~h})$, risk of rescue antiemetic drug $(0-24 \mathrm{~h})$, adverse effects of plaster. } \\
\hline Notes & \multicolumn{2}{|c|}{$\begin{array}{l}\text { Nausea ( }(0-6 \mathrm{~h}) \text {, vomiting }(0-6 \mathrm{~h}) \text {, incidence of rescue antiemetic }(0-6 \mathrm{~h}) \text { also reported. Rescue antiemetic } \\
\text { was ondansetron } 4 \mathrm{mg} \text { IV for patients with persistent nausea for more than } 5 \mathrm{~min} \text {, two or more episodes } \\
\text { of vomiting/retching, or at patient's request for PONV treatment. "One patient complained of mild } \\
\text { irritation at the site of capsicum plaster application. No other adverse effects attributable to acu- } \\
\text { stimulation or ondansetron were observed". }\end{array}$} \\
\hline \multicolumn{3}{|l|}{ Risk of bias } \\
\hline Item & Authors' judgement & Description \\
\hline Adequate sequence generation? & Yes & $\begin{array}{l}\text { "The subjects were randomly assigned to one of the } \\
\text { three groups using a computer-generated random } \\
\text { number table". }\end{array}$ \\
\hline Allocation concealment? & Unclear & Insufficient information. \\
\hline $\begin{array}{l}\text { Incomplete outcome data } \\
\text { addressed? All outcomes }\end{array}$ & Yes & $\begin{array}{l}\text { Reasons for withdrawals given. No missing data } \\
\text { reported for the } 120 \text { patients analysed. }\end{array}$ \\
\hline Free of selective reporting? & Yes & All expected outcomes reported. \\
\hline
\end{tabular}




\begin{tabular}{l|l|l} 
Free of other bias? & Yes & $\begin{array}{l}\text { Baseline characteristics were comparable. "The } \\
\text { demographic characteristics of the three groups were } \\
\text { similar, as were history of previous PONV and motion } \\
\text { sickness". }\end{array}$ \\
\hline Blinding of patients? All outcomes & Yes & $\begin{array}{l}\text { Authors took adequate steps to make interventions } \\
\text { appear similar. }\end{array}$ \\
\hline $\begin{array}{l}\text { Blinding of healthcare providers? } \\
\text { All outcomes }\end{array}$ & Yes & $\begin{array}{l}\text { "Anesthesia was standardized and given by an } \\
\text { anesthesiologist blinded to group assignment". }\end{array}$ \\
\hline $\begin{array}{l}\text { Blinding of outcome assessor? All } \\
\text { outcomes }\end{array}$ & Yes & $\begin{array}{l}\text { "The incidence of PONV was evaluated within six } \\
\text { hours and } 24 \text { hr after transfer to the postoperative unit } \\
\text { by a blinded observer". }\end{array}$ \\
\hline
\end{tabular}

Rusy 2002

\begin{tabular}{|l|l} 
Methods & Randomized block design procedure was used. Arms were covered with full-length soft restraints so the
\end{tabular} needle positions could not be seen. Recovery room nurses were blinded to treatment groups. Patients were asked to record nausea and vomiting over $24 \mathrm{~h}$ after discharge from hospital.

\begin{tabular}{l|l}
\hline Participants & 121 Children (4-18 years) undergoing tonsillectomy with or without adenoidectomy. Exclusions: \\
\hline
\end{tabular} presence of skin lesions near acupuncture sites, previous and severe PONV, chronic history of nausea and vomiting. One child disqualified after enrolment when propofol was administered during the anaesthetic.

\begin{tabular}{|c|c|c|}
\hline Interventions & \multicolumn{2}{|c|}{$\begin{array}{l}\text { Electro-acupuncture at } \mathrm{P} 6 \text { for } 20 \mathrm{~min} \text { after patient was awake. } \\
\text { Sham electro-acupuncture at P2 for } 20 \text { min after patient was awake. } \\
\text { Sham reference group had no needles inserted. Insulated wires were attached to insides of arm and } \\
\text { stimulation box was activated to maintain blinding. }\end{array}$} \\
\hline Outcomes & \multicolumn{2}{|c|}{ Vomiting $(0-24 \mathrm{~h})$, nausea $(0-24 \mathrm{~h})$, risk of rescue antiemetic drugs. } \\
\hline Notes & \multicolumn{2}{|c|}{$\begin{array}{l}\text { Rescue antiemetics were ondansetron and droperidol IV. Sham electro-acupuncture and sham reference } \\
\text { group data were combined. }\end{array}$} \\
\hline \multicolumn{3}{|l|}{ Risk of bias } \\
\hline Item & Authors' judgement & Description \\
\hline Adequate sequence generation? & Yes & $\begin{array}{l}\text { "A randomized block design procedure was used to } \\
\text { assign enrollees to one of three groups..". }\end{array}$ \\
\hline Allocation concealment? & Unclear & Insufficient information. \\
\hline $\begin{array}{l}\text { Incomplete outcome data } \\
\text { addressed? All outcomes }\end{array}$ & Yes & $\begin{array}{l}\text { Reason for withdrawal of one patients was given. No } \\
\text { missing data reported for } 120 \text { patients analysed. }\end{array}$ \\
\hline Free of selective reporting? & Unclear & $\begin{array}{l}\text { There was no description about side effects of therapy } \\
\text { in the trial, but in the correspondence (Rusy 2002) the } \\
\text { authors wrote "There were no noted muscle } \\
\text { contractions or patients who complained of paresthesias } \\
\text { during the study". }\end{array}$ \\
\hline Free of other bias? & Yes & $\begin{array}{l}\text { Baseline characteristics were comparable. "The groups } \\
\text { were similar for age, sex, weight, analgesics } \\
\text { administered, and surgical time (Table 1), with no } \\
\text { differences found". }\end{array}$ \\
\hline Blinding of patients? All outcomes & Yes & $\begin{array}{l}\text { Authors took adequate steps to make interventions } \\
\text { appear similar. }\end{array}$ \\
\hline $\begin{array}{l}\text { Blinding of healthcare providers? } \\
\text { All outcomes }\end{array}$ & Yes & $\begin{array}{l}\text { "Experienced recovery room nurses, who were blinded } \\
\text { to the treatment group, assessed nausea and vomiting". }\end{array}$ \\
\hline $\begin{array}{l}\text { Blinding of outcome assessor? All } \\
\text { outcomes }\end{array}$ & Yes & $\begin{array}{l}\text { "Experienced recovery room nurses, who were blinded } \\
\text { to the treatment group, assessed nausea and vomiting". }\end{array}$ \\
\hline \multicolumn{3}{|l|}{ Samad 2003} \\
\hline Methods & \multicolumn{2}{|c|}{$\begin{array}{l}\text { Patients randomly assigned by random table number. Blinded observer evaluated outcomes. Unclear } \\
\text { whether patients were blinded as the wristband was not covered by gauze. Anaesthetist caring for the } \\
\text { patient was most likely to be blinded as the intervention was given by investigators not involved with } \\
\text { patient care. }\end{array}$} \\
\hline Participants & \multicolumn{2}{|c|}{$\begin{array}{l}50 \text { Male and female patients }(18-60 \mathrm{y} \text { ) undergoing laparoscopic cholecystectomy. Exclusion: obesity } \\
\text { (weight }>80 \mathrm{~kg} \text { ), diabetics, patients with history of postoperative nausea and vomiting, patients } \\
\text { receiving antiemetics and histamine } \mathrm{H} 2 \text { antagonists. }\end{array}$} \\
\hline
\end{tabular}


Interventions

Acupressure band on right hand at P6 acupoint half an hour before induction of anaesthesia, and kept on for 6 hours after surgery.

Sham acupressure band on right hand with plastic bead placed on the dorsum of forearm.

\begin{tabular}{l|l}
\hline Outcomes & Nausea $(0-6 \mathrm{~h})$, vomiting $(0-6 \mathrm{~h})$, risk of rescue antiemetic drug, side effects. \\
\hline Notes & $\begin{array}{l}\text { Rescue antiemetic was metoclopramide } 10 \mathrm{mg} \text { IV for nausea or vomiting. No side effects or } \\
\text { complications associated with either intervention. }\end{array}$ \\
\hline
\end{tabular}

Risk of bias

\begin{tabular}{|c|c|c|}
\hline Item & Authors' judgement & Description \\
\hline Adequate sequence generation? & Yes & $\begin{array}{l}\text { "Patients were randomly assigned by random table } \\
\text { number to either group..". }\end{array}$ \\
\hline Allocation concealment? & Unclear & Insufficient information. \\
\hline $\begin{array}{l}\text { Incomplete outcome data } \\
\text { addressed? All outcomes }\end{array}$ & Yes & No missing data reported for 50 patients analysed. \\
\hline Free of selective reporting? & Yes & All expected outcomes reported. \\
\hline Free of other bias? & Yes & $\begin{array}{l}\text { Baseline characteristics were comparable. "There was } \\
\text { no statistically significant difference with respect to } \\
\text { age, sex, weight and duration of surgery between the } \\
\text { two groups (Table 1)". }\end{array}$ \\
\hline Blinding of patients? All outcomes & Yes & $\begin{array}{l}\text { Authors took adequate steps to make interventions } \\
\text { appear similar. }\end{array}$ \\
\hline $\begin{array}{l}\text { Blinding of healthcare providers? } \\
\text { All outcomes }\end{array}$ & Unclear & Insufficient information. \\
\hline $\begin{array}{l}\text { Blinding of outcome assessor? All } \\
\text { outcomes }\end{array}$ & Yes & $\begin{array}{l}\text { "A blinded observer in the recovery room (one of the } \\
\text { investigator not involved in applying acupressure band) } \\
\text { evaluated the patients for presence of nausea and } \\
\text { vomiting...". }\end{array}$ \\
\hline \multicolumn{3}{|l|}{ Schlager 1998} \\
\hline Methods & \multicolumn{2}{|c|}{$\begin{array}{l}\text { Method of allocation concealment not given. Risk of vomiting recorded by nursing staff in the recovery } \\
\text { room and on the ward. }\end{array}$} \\
\hline Participants & \multicolumn{2}{|c|}{$\begin{array}{l}40 \text { Children ( } 3 \text { to } 12 \text { years) undergoing strabismus surgery. Excluded: children with gastric or intestinal } \\
\text { disease, emesis and vomiting in the previous week, and those who received any medical therapy } \\
\text { immediately before surgery. No child withdrew from study. }\end{array}$} \\
\hline Interventions & \multicolumn{2}{|c|}{$\begin{array}{l}\text { Low-level laser stimulation performed on each P6 acupoint over } 30 \text { seconds, } 15 \text { minutes before } \\
\text { induction of anaesthesia and } 15 \text { minutes after arriving in the recovery room. } \\
\text { Sham laser stimulation held on P6 acupoints but laser beam not activated, } 15 \text { minutes before induction } \\
\text { of anaesthesia and } 15 \text { minutes after arriving in the recovery room. }\end{array}$} \\
\hline Outcomes & \multicolumn{2}{|c|}{ Vomiting $(0-24 \mathrm{~h})$, risk of rescue antiemetic drug. } \\
\hline Notes & \multicolumn{2}{|c|}{$\begin{array}{l}\text { Rescue antiemetic was dimenhydrinate suppositories } 50 \mathrm{mg} \text {. Nurses in the recovery room may not have } \\
\text { been blinded to treatment groups. Vomiting }(0-2 \mathrm{~h}, 0-6 \mathrm{~h}) \text { also recorded in the paper. }\end{array}$} \\
\hline
\end{tabular}

Risk of bias

\begin{tabular}{l|l|l}
\hline Item & Authors' judgement & Description \\
\hline Adequate sequence generation? & Unclear & Insufficient information. \\
\hline Allocation concealment? & Unclear & Insufficient information. \\
\hline $\begin{array}{l}\text { Incomplete outcome data } \\
\text { addressed? All outcomes }\end{array}$ & Yes & No missing data reported for 40 children analysed. \\
\hline Free of selective reporting? & Unclear & $\begin{array}{l}\text { Risk of nausea was not recorded because it may be } \\
\text { difficult to assess in children. Authors stated that } \\
\text { "stimulation of P6 with a low-level laser has no known } \\
\text { side effects". }\end{array}$ \\
\hline Free of other bias? & & $\begin{array}{l}\text { Baseline characteristics were comparable. "There were } \\
\text { no significant differences between the groups in age, } \\
\text { sex distribution, ASA status, weight, height, duration of }\end{array}$
\end{tabular}




\begin{tabular}{l|l|l} 
& & $\begin{array}{l}\text { anaesthesia, duration of surgery or number of repaired } \\
\text { muscles (Table 1)". }\end{array}$ \\
\hline Blinding of patients? All outcomes & Yes & $\begin{array}{l}\text { Authors took adequate steps to make interventions } \\
\text { appear similar. "Neither children nor parents were able } \\
\text { to tell if the laser was active". }\end{array}$ \\
\hline $\begin{array}{l}\text { Blinding of healthcare providers? } \\
\text { All outcomes }\end{array}$ & Unclear & Insufficient information. \\
\hline $\begin{array}{l}\text { Blinding of outcome assessor? All } \\
\text { outcomes }\end{array}$ & Unclear & Insufficient information. \\
\hline
\end{tabular}

Schultz 2003

\begin{tabular}{|l|l} 
Methods & Study envelopes with the group allocations were prepared by the principal investigator and the study
\end{tabular} pharmacist using a random number table. The envelopes were opened by the admitting nurse. Nurses documented outcomes.

Participants

103 Women undergoing gynaecological surgery. Exclusions: pregnancy, surgery for cancer within the previous 5 years, chemotherapy or radiation therapy within 5 years, an antiemetic within 24 hours before surgery, previous use of acupressure bands, or peripheral neuropathy. 40 women withdrew before completion of trial due to non-administration of study drug and change in postoperative plans due to earlier hospital discharge.

\begin{tabular}{l|l}
\hline Interventions & Group 1: droperidol $1.25 \mathrm{mg}$ IV at induction and acupressure wristband at P6 acupoint on both wrists
\end{tabular} before surgery (worn up to 48 hours after surgery).

Group 2: droperidol $1.25 \mathrm{mg}$ IV at induction and sham acupressure wristband at P6 acupoint on both wrists before surgery (worn up to 48 hours after surgery). Sham acupressure wristband had flat button which did not exert pressure on P6 acupoint.

Group 3: normal saline IV at induction and acupressure wristband at P6 acupoint on both wrists before surgery (worn up to 48 hours after surgery).

Group 4: normal saline IV at induction and sham acupressure wristband at P6 acupoint on both wrists before surgery (worn up to 48 hours after surgery).

\begin{tabular}{l|l}
\hline Outcomes & Nausea (0-duration of hospital stay), vomiting (0-hospital stay). \\
\hline Notes & $\begin{array}{l}\text { Authors replied to our request for unpublished data for incidence of nausea and vomiting during } \\
\text { hospital stay. }\end{array}$ \\
\hline Risk of bias
\end{tabular}

\section{Risk of bias}

\begin{tabular}{l|l|l}
\hline Item & Authors' judgement & Description \\
\hline Adequate sequence generation? & Yes & Used random number table. \\
\hline Allocation concealment? & Yes & $\begin{array}{l}\text { "Study envelopes with the appropriate acupressure } \\
\text { band and drug preparation were prepared by the } \\
\text { principal investigator and the study pharmacist.... The } \\
\text { packets were kept in a secure area of the surgical } \\
\text { admitting department. The envelope, containing the } \\
\text { study group designation, was opened by the admitting } \\
\text { nurse...". }\end{array}$ \\
\hline $\begin{array}{l}\text { Incomplete outcome data } \\
\text { addressed? All outcomes }\end{array}$ & No & $\begin{array}{l}\text { Although 40 women withdrew from the study, reasons } \\
\text { were given. "There was no statistically significant } \\
\text { difference in the age of the 103 women who continued } \\
\text { in the study as compared with 40 women who did not } \\
\text { complete the study". Of the 103 women recruited, 95 } \\
\text { and 62 women had complete data for nausea and } \\
\text { vomiting during hospital stay respectively. Comment: } \\
\text { missing data likely to bias the summary effect measure. }\end{array}$ \\
\hline Free of selective reporting? & No & $\begin{array}{l}\text { Risk of side-effects and use of rescue antiemetic drugs } \\
\text { were not described in the paper. }\end{array}$ \\
\hline Free of other bias? & Yes & $\begin{array}{l}\text { Baseline characteristics appeared to be comparable. } \\
\text { There was no difference among the groups for age, type } \\
\text { of surgery, duration of surgery, duration of acupressure } \\
\text { wristband use. }\end{array}$ \\
\hline $\begin{array}{l}\text { Blinding of healthcare providers? } \\
\text { All outcomes }\end{array}$ & Unclear & $\begin{array}{l}\text { Authors took adequate steps to make interventions } \\
\text { appear similar. }\end{array}$ \\
\hline & Yes & \begin{tabular}{l} 
Insufficient information. \\
\hline
\end{tabular} \\
\hline
\end{tabular}




\begin{tabular}{|c|c|}
\hline $\begin{array}{l}\text { Blinding of outcome assessor? All } \\
\text { outcomes }\end{array}$ & Unclear \\
\hline \multicolumn{2}{|l|}{ Sharma 2007} \\
\hline Methods & Method of allocation concealment not given. No blinding. \\
\hline Participants & $\begin{array}{l}60 \text { Women undergoing laparoscopic cholecystectomies under general anaesthesia. Exclusion: obesity, } \\
\text { previous history of PONV and motion sickness. }\end{array}$ \\
\hline Interventions & $\begin{array}{l}\text { Group 1: ondansetron } 4 \mathrm{mg} \text { IV given } 10 \mathrm{~min} \text { after induction of anaesthesia. } \\
\text { Group 2: bilateral P6 acupuncture } 5 \text { minutes before induction of anaesthesia. Intermittent stimulation } \\
\text { was given at P6 acupoints by rotating needle clockwise and anticlockwise up to } 30 \mathrm{~min} \text {. } \\
\text { Group 3: combination of group } 1 \text { and group } 2 \text { interventions. }\end{array}$ \\
\hline Outcomes & Nausea $(0-7 \mathrm{~h})$, vomiting $(0-7 \mathrm{~h})$, risk of rescue antiemetic drug $(0-7 \mathrm{~h})$, risk of adverse effects. \\
\hline Notes & $\begin{array}{l}\text { Rescue antiemetic was metoclopramide } 10 \mathrm{mg} \text { IV. Data in group } 3 \text { was not used in any of the meta- } \\
\text { analyses. No pain, bleeding, vasovagal attack, or broken acupuncture needles noted in any of the } \\
\text { groups. }\end{array}$ \\
\hline
\end{tabular}

\section{Risk of bias}

\begin{tabular}{|c|c|c|}
\hline Item & Authors' judgement & Description \\
\hline Adequate sequence generation? & Unclear & Insufficient information. \\
\hline Allocation concealment? & Unclear & Insufficient information. \\
\hline $\begin{array}{l}\text { Incomplete outcome data } \\
\text { addressed? All outcomes }\end{array}$ & Yes & No missing data reported for 60 women analysed. \\
\hline Free of selective reporting? & Yes & All expected outcomes reported. \\
\hline Free of other bias? & Yes & $\begin{array}{l}\text { Baseline characteristics were comparable. "There was } \\
\text { no significant difference among the patients in both the } \\
\text { groups regarding weight, age, height, gender, hours of } \\
\text { preoperative fasting and duration of anesthesia and } \\
\text { surgery...". }\end{array}$ \\
\hline Blinding of patients? All outcomes & No & $\begin{array}{l}\text { "Blinding of any form was not possible because } \\
\text { acupuncture needles had to be kept in situ in the } \\
\text { operating room". }\end{array}$ \\
\hline $\begin{array}{l}\text { Blinding of healthcare providers? } \\
\text { All outcomes }\end{array}$ & No & $\begin{array}{l}\text { "Blinding of any form was not possible because } \\
\text { acupuncture needles had to be kept in situ in the } \\
\text { operating room". }\end{array}$ \\
\hline $\begin{array}{l}\text { Blinding of outcome assessor? All } \\
\text { outcomes }\end{array}$ & No & $\begin{array}{l}\text { "Blinding of any form was not possible because } \\
\text { acupuncture needles had to be kept in situ in the } \\
\text { operating room". }\end{array}$ \\
\hline
\end{tabular}

Shenkman 1999

\begin{tabular}{l|l} 
Methods & $\begin{array}{l}\text { Method of allocation concealment not given. Recovery room nurses and ward nurses were blinded to } \\
\text { treatment groups. P6 acupoints and sham points on all patients were covered with opaque adhesive tape. }\end{array}$ \\
\hline Participants & $\begin{array}{l}\text { 100 Children (2-12 years) undergoing tonsillectomy. Exclusion: congenital heart disease or significant } \\
\text { pulmonary disease, predisposition for emesis or actual emesis in the 24 hours before surgery, use of } \\
\text { medications with antiemetic effects within the 24 hours before surgery, infection over an acupuncture } \\
\text { point, need for postoperative intubation for more than 1 hour, and severe obstructive sleep apnoea. }\end{array}$ \\
\hline Interventions & $\begin{array}{l}\text { Group 1: acupressure wristband on P6 acupoints of both wrists applied before premedication. } \\
\text { Immediately after induction of anaesthesia, wristbands were removed and acupuncture needles were } \\
\text { inserted at P6 acupoint on both wrists, left in place until next day. Needles were secured with a strip of } \\
\text { tape. } \\
\text { Group 2: acupressure wristbands applied to sham point on both arms before premedication. }\end{array}$ \\
$\begin{array}{l}\text { Immediately after induction of anaesthesia, wristbands were removed and acupuncture needles were } \\
\text { applied to sham point on both arms, left in place until next day. Needles were secured with a strip of } \\
\text { tape. }\end{array}$ \\
\hline Outcomes & \begin{tabular}{l} 
Vomiting (0-24h), risk of rescue antiemetic drug, side effects of acupressure/acupuncture. \\
\hline Notes
\end{tabular} \\
$\begin{array}{ll}\text { Rescue antiemetic was ondansetron IV if two or more emetic episodes occurred. Combination of } \\
\text { acupressure and acupuncture treatment effect was not analysed in subgroup analysis (invasive versus } \\
\text { noninvasive). Proportion of acupuncture site redness and irritation was similar in both groups. }\end{array}$ \\
\hline
\end{tabular}




\begin{tabular}{|c|c|c|}
\hline Item & Authors' judgement & Description \\
\hline Adequate sequence generation? & Unclear & insufficient information. \\
\hline Allocation concealment? & Unclear & Insufficient information. \\
\hline $\begin{array}{l}\text { Incomplete outcome data } \\
\text { addressed? All outcomes }\end{array}$ & Yes & No missing data reported for 100 patients analysed. \\
\hline Free of selective reporting? & Yes & All expected outcomes reported. \\
\hline Free of other bias? & Yes & $\begin{array}{l}\text { Baseline characteristics were comparable. "There were } \\
\text { no differences between the groups with regard to } \\
\text { demographics or previous retching, vomiting, or either } \\
\text { (table 2)". }\end{array}$ \\
\hline Blinding of patients? All outcomes & Yes & $\begin{array}{l}\text { Authors took adequate steps to make interventions } \\
\text { appear similar. }\end{array}$ \\
\hline $\begin{array}{l}\text { Blinding of healthcare providers? } \\
\text { All outcomes }\end{array}$ & Yes & $\begin{array}{l}\text { "Postanesthesia care unit and ward nurses who assessed } \\
\text { and charted postoperative emesis and medication } \\
\text { administration were blinded to the group assignment of } \\
\text { each patient". }\end{array}$ \\
\hline $\begin{array}{l}\text { Blinding of outcome assessor? All } \\
\text { outcomes }\end{array}$ & Yes & $\begin{array}{l}\text { "Postanesthesia care unit and ward nurses who assessed } \\
\text { and charted postoperative emesis and medication } \\
\text { administration were blinded to the group assignment of } \\
\text { each patient". }\end{array}$ \\
\hline \multicolumn{3}{|l|}{ Streitberger 2004} \\
\hline Methods & \multicolumn{2}{|c|}{$\begin{array}{l}\text { Acupuncturist obtained randomization allocation by phone from a member of the university clinical } \\
\text { trials centre, who had no contact with study patients. Authors wrote "an adequate allocation } \\
\text { concealment was thereby assured“. Patients, outcome assessor, nurses, anaesthetists, and all other staff } \\
\text { members were not informed about the allocation. Blinding of the patients was ensured by using a } \\
\text { placebo needle that simulated an acupuncture procedure without penetrating the skin. Intention-to-treat } \\
\text { analysis was used. }\end{array}$} \\
\hline Participants & \multicolumn{2}{|c|}{$\begin{array}{l}212 \text { Females undergoing gynaecological or breast surgery under general anaesthesia. Exclusion: } \\
\text { acupuncture treatment during the last } 6 \text { months, pregnancy, nausea or vomiting during the past } 24 \mathrm{~h} \text {, } \\
\text { lymphoedema of the upper limbs, eczematous skin changes at the P6 acupoint, and coagulopathy. One } \\
\text { patient in the acupuncture group withdrew consent and was treated as a failure in the analysis. }\end{array}$} \\
\hline Interventions & \multicolumn{2}{|c|}{$\begin{array}{l}\text { Acupuncture group: } 52 \text { patients had acupuncture to P6 acupoint on both wrists, } 20 \text { min before induction } \\
\text { of anaesthesia; another } 54 \text { patients had acupuncture to P6 acupoint on both wrists immediately after } \\
\text { induction of anaesthesia. } \\
\text { Sham acupuncture: } 51 \text { patients had placebo acupuncture to P6 acupoint on both wrists, } 20 \text { min before } \\
\text { induction of anaesthesia; another } 55 \text { patients had placebo acupuncture to P6 acupoint on both wrists } \\
\text { immediately after induction of anaesthesia. }\end{array}$} \\
\hline Outcomes & \multicolumn{2}{|c|}{$\begin{array}{l}\text { Nausea ( } 0-24 \mathrm{~h}) \text {, vomiting }(0-24 \mathrm{~h}) \text {, risk of rescue antiemetic drugs, adverse events related to } \\
\text { acupuncture. }\end{array}$} \\
\hline Notes & \multicolumn{2}{|c|}{$\begin{array}{l}\text { Dimenhydinate and dolasetron rescue antiemetics used. Haematomas reported by one patient in the } \\
\text { acupuncture group and by two patients in the placebo acupuncture group. Allergy to sticky plaster } \\
\text { reported by } 5 \text { patients in each group. No severe adverse reaction reported. }\end{array}$} \\
\hline \multicolumn{3}{|l|}{ Risk of bias } \\
\hline Item & Authors' judgement & Description \\
\hline Adequate sequence generation? & Unclear & $\begin{array}{l}\text { "The patients were randomly distributed by type of } \\
\text { surgery (gynaecological or breast) to ensure balance } \\
\text { between groups". Comment: no further details provided } \\
\text { in the paper. }\end{array}$ \\
\hline Allocation concealment? & Yes & $\begin{array}{l}\text { "The acupuncturist obtained randomisation allocation } \\
\text { by phone from a member of the Coordination Centre } \\
\text { for Clinical Trials, University of Heidelberg, who had } \\
\text { no contact with study patients. An adequate } \\
\text { concealment was thereby assured“. }\end{array}$ \\
\hline $\begin{array}{l}\text { Incomplete outcome data } \\
\text { addressed? All outcomes }\end{array}$ & Yes & $\begin{array}{l}\text { Reasons for withdrawals given. Intention-to-treat } \\
\text { analysis used. }\end{array}$ \\
\hline Free of selective reporting? & Yes & All expected outcomes reported. \\
\hline
\end{tabular}




\begin{tabular}{l|l|l} 
Free of other bias? & Yes & $\begin{array}{l}\text { Baseline characteristics were comparable. "Baseline } \\
\text { characteristics revealed no relevant differences between } \\
\text { the two groups (Table 1)“. }\end{array}$ \\
\hline Blinding of patients? All outcomes & Yes & $\begin{array}{l}\text { Authors took adequate steps to make interventions } \\
\text { appear similar. To assess blinding, patients were asked } \\
\text { what kind of needle they believe they had received". }\end{array}$ \\
\hline $\begin{array}{l}\text { Blinding of healthcare providers? } \\
\text { All outcomes }\end{array}$ & Yes & $\begin{array}{l}\text { "The patients, the observer of the endpoints, the nurses, } \\
\text { the anaesthetists and all other staff members were not } \\
\text { informed about the allocation". }\end{array}$ \\
\hline $\begin{array}{l}\text { Blinding of outcome assessor? All } \\
\text { outcomes }\end{array}$ & Yes & $\begin{array}{l}\text { "The patients, the observer of the endpoints, the nurses, } \\
\text { the anaesthetists and all other staff members were not } \\
\text { informed about the allocation". }\end{array}$ \\
\hline Tavlan 1996 & \multicolumn{2}{|l}{} \\
\hline Methods & $\begin{array}{l}\text { Method of allocation concealment not given. No details about blinding. This study was reported as an } \\
\text { abstract. }\end{array}$ \\
\hline Participants & 65 Women (18-45 years) undergoing gynaecological laparoscopy. \\
\hline Interventions & $\begin{array}{l}\text { Group 1: ondansetron 8 mg IV before induction. } \\
\text { Group 2: } 0.2 \text { ml 50\% dextrose on the P6 acupoint before induction. } \\
\text { Group 3: 20 ml IV saline before induction. }\end{array}$ \\
\hline Outcomes & Nausea (0-1h), vomiting (0-1h). \\
\hline Notes & Group 3 (n=20) not used in the acupoint P6 stimulation versus sham analyses. \\
\hline
\end{tabular}

Risk of bias

\begin{tabular}{|c|c|c|}
\hline Item & Authors' judgement & Description \\
\hline Adequate sequence generation? & Unclear & Insufficient information. \\
\hline Allocation concealment? & Unclear & Insufficient information. \\
\hline $\begin{array}{l}\text { Incomplete outcome data } \\
\text { addressed? All outcomes }\end{array}$ & Yes & No missing data reported for 65 patients analysed. \\
\hline Free of selective reporting? & Unclear & $\begin{array}{l}\text { Risk of side effects and rescue antiemetic drugs not } \\
\text { given because the article was an abstract. }\end{array}$ \\
\hline Free of other bias? & Yes & $\begin{array}{l}\text { Baseline characteristics were comparable. "No } \\
\text { significant differences were observed between the } \\
\text { groups in terms of demography". }\end{array}$ \\
\hline Blinding of patients? All outcomes & Unclear & Insufficient information. \\
\hline $\begin{array}{l}\text { Blinding of healthcare providers? } \\
\text { All outcomes }\end{array}$ & Unclear & Insufficient information. \\
\hline $\begin{array}{l}\text { Blinding of outcome assessor? All } \\
\text { outcomes }\end{array}$ & Unclear & Insufficient information. \\
\hline \multicolumn{3}{|l|}{ Turgut 2007} \\
\hline Methods & \multicolumn{2}{|c|}{$\begin{array}{l}\text { Authors stated that patients were randomized using closed envelopes into one of two groups. In both } \\
\text { groups, wristbands were covered by loose gauze to ensure observer-blinding. Anaesthesiologists caring } \\
\text { for the patients were not aware of group assignment. Outcome assessor appears to be blinded to } \\
\text { treatment allocation. }\end{array}$} \\
\hline Participants & \multicolumn{2}{|c|}{$\begin{array}{l}102 \text { Women aged } 40 \text { to } 65 \text { years, with no previous experience of acupressure bands, undergoing } \\
\text { elective gynaecological surgery (total abdominal hysterectomy and bilateral salpingo-oophorectomy). } \\
\text { One patient in acupressure group and one in sham group withdrew because of swelling and erythema in } \\
\text { treated hand and protocol violation respectively. Exclusion criteria: obesity (body mass index > 30), } \\
\text { diabetes, history of motion sickness, postoperative nausea and vomiting, or smoking. }\end{array}$} \\
\hline Interventions & \multicolumn{2}{|c|}{$\begin{array}{l}\text { Acupressure group: wristband with plastic bead positioned at P6 point on both wrists, } 30 \text { minutes before } \\
\text { induction of general anaesthesia. Wristbands left on for } 24 \text { hours. Sham group: wristband with plastic } \\
\text { bead positioned at non-acupoint site on the dorsal surface of both forearm, } 30 \text { minutes before induction } \\
\text { of general anaesthesia. Wristbands left on for } 24 \text { hours. } \\
\text { Both groups were educated on the use of patient controlled analgesia before surgery. Patients received } \\
\text { patient controlled analgesia containing morphine in the postanaesthetic care room, and continued for } 24 \\
\text { hours. }\end{array}$} \\
\hline
\end{tabular}




\begin{tabular}{l|l} 
Outcomes & Nausea $(0-24 \mathrm{~h})$, vomiting $(0-24 \mathrm{~h})$, rescue antiemetic drug use, adverse effects of wristbands. \\
\hline Notes & $\begin{array}{l}\text { Risks of nausea and vomiting on arrival in recovery room reported. No adverse effects or complications } \\
\text { were observed due to acupressure wristbands, except for one patient in the acupressure group who } \\
\text { withdrew due to swelling and erythema of the treated hand. Rescue antiemetic was metoclopramide 10 } \\
\text { mg IV. }\end{array}$ \\
\hline
\end{tabular}

\begin{tabular}{|c|c|c|}
\hline \multicolumn{3}{|l|}{ Risk of bias } \\
\hline Item & Authors' judgement & Description \\
\hline Adequate sequence generation? & Unclear & Insufficient information. \\
\hline Allocation concealment? & Unclear & Insufficient information. \\
\hline $\begin{array}{l}\text { Incomplete outcome data } \\
\text { addressed? All outcomes }\end{array}$ & Yes & $\begin{array}{l}\text { Reasons for withdrawal given. No missing data } \\
\text { reported for } 100 \text { patients analysed. }\end{array}$ \\
\hline Free of selective reporting? & Yes & All expected outcomes reported. \\
\hline Free of other bias? & Yes & $\begin{array}{l}\text { "Patients of both groups were comparable with regard } \\
\text { to age, weight, height, ASA physical status and } \\
\text { duration of surgery (Table 1)". }\end{array}$ \\
\hline Blinding of patients? All outcomes & Yes & $\begin{array}{l}\text { Authors took adequate steps to make interventions } \\
\text { appear similar. }\end{array}$ \\
\hline $\begin{array}{l}\text { Blinding of healthcare providers? } \\
\text { All outcomes }\end{array}$ & Yes & $\begin{array}{l}\text { "The anaesthesiologists caring for the patients were not } \\
\text { aware of group assignment". }\end{array}$ \\
\hline $\begin{array}{l}\text { Blinding of outcome assessor? All } \\
\text { outcomes }\end{array}$ & Yes & "The study was observer-blinded". \\
\hline \multicolumn{3}{|l|}{ Wang 2002} \\
\hline Methods & \multicolumn{2}{|c|}{$\begin{array}{l}\text { Yoking randomization procedure used. Children, parents, surgeons, anaesthetists, Recovery room } \\
\text { nurses and research assistant were blinded to treatment groups. Small adhesive bandages applied to P6 } \\
\text { acupoints on all subjects. }\end{array}$} \\
\hline Participants & \multicolumn{2}{|c|}{$\begin{array}{l}190 \text { Children ( } 7-16 \text { years) undergoing general anaesthesia and outpatient surgical procedures. } \\
\text { Exclusions: ASA physical status higher than II and subjects with a history of developmental delay or } \\
\text { prematurity. Three children were excluded from study because of major study protocol violations. }\end{array}$} \\
\hline Interventions & \multicolumn{2}{|c|}{$\begin{array}{l}\text { Group 1: after induction, intravenous saline was given. Acupuncture at P6 acupoints on both arms was } \\
\text { performed before end of surgery. Injection of } 0.2 \mathrm{~mL} \text { of } 50 \% \text { dextrose using a B-D } 1 \mathrm{~mL} \text { tuberculin } \\
\text { syringe with a } 25 \text {-gauge needle at a depth of } 5 \text { to } 7 \mathrm{~mm} \text { from skin. } \\
\text { Group 2: after induction, droperidol } 10 \mathrm{ug} / \mathrm{kg} \text { IV was given. Superficial skin prick at the } \mathrm{P} 6 \text { acupoint } \\
\text { was performed before end of surgery. } \\
\text { Group 3: after induction, intravenous saline was given. Sham point acupuncture at the dorsum of arms } \\
\text { was performed before end of surgery. Injection of } 0.2 \mathrm{~mL} \text { of } 50 \% \text { dextrose using a B-D } 1 \mathrm{~mL} \text { tuberculin } \\
\text { syringe with a } 25 \text {-gauge needle at a depth of } 5 \text { to } 7 \mathrm{~mm} \text { from skin. } \\
\text { Group 4: after induction, intravenous saline was given. Superficial skin prick at the P6 acupoint was } \\
\text { performed before end of surgery. }\end{array}$} \\
\hline Outcomes & \multicolumn{2}{|c|}{ Nausea (0-recovery room), vomiting (0-recovery room), risk of rescue antiemetic drug. } \\
\hline Notes & \multicolumn{2}{|c|}{$\begin{array}{l}\text { Rescue antiemetic was ondansetron IV } 0.1-4 \mathrm{mg} / \mathrm{kg} \text {. Group } 3 \text { and } 4 \text { were combined and considered as a } \\
\text { sham group. No puncture site redness or irritation noted in any of the groups. Late outcomes (discharge } \\
\text { to first day after surgery) also reported. No data on outcomes }(0-24 \mathrm{~h}) \text { according to author. }\end{array}$} \\
\hline
\end{tabular}

Risk of bias

\begin{tabular}{l|l|l} 
Item & Authors' judgement & Description \\
\hline Adequate sequence generation? & Yes & $\begin{array}{l}\text { Yoking randomization (based on computer-generated } \\
\text { list) was used to equal distribution of variables that are } \\
\text { known to affect the outcome. }\end{array}$ \\
\hline Allocation concealment? & Unclear & Insufficient information. \\
\hline $\begin{array}{l}\text { Incomplete outcome data } \\
\text { addressed? All outcomes }\end{array}$ & Yes & $\begin{array}{l}\text { Details about withdrawals were given. No missing data } \\
\text { reported for 187 children analysed. }\end{array}$ \\
\hline Free of selective reporting? & Yes & All expected outcomes reported. \\
\hline Free of other bias? & Yes & $\begin{array}{l}\text { Baseline characteristics were comparable. "There were } \\
\text { no differences among the various study groups in }\end{array}$
\end{tabular}




\begin{tabular}{l|l|l} 
& & $\begin{array}{l}\text { regard to baseline demographic characteristics such as } \\
\text { age and history of PONV (Table 1)". }\end{array}$ \\
\hline Blinding of patients? All outcomes & Yes & $\begin{array}{l}\text { Authors took adequate steps to make interventions } \\
\text { appear similar. "Children, parents, surgeons, } \\
\text { anesthesiologists, PACU nursing staff, and the research } \\
\text { assistant, were all blinded to group assignment". }\end{array}$ \\
\hline $\begin{array}{l}\text { Blinding of healthcare providers? } \\
\text { All outcomes }\end{array}$ & Yes & $\begin{array}{l}\text { "Children, parents, surgeons, anesthesiologists, PACU } \\
\text { nursing staff, and the research assistant, were all } \\
\text { blinded to group assignment". }\end{array}$ \\
\hline $\begin{array}{l}\text { Blinding of outcome assessor? All } \\
\text { outcomes }\end{array}$ & Yes & $\begin{array}{l}\text { "Children, parents, surgeons, anesthesiologists, PACU } \\
\text { nursing staff, and the research assistant, were all } \\
\text { blinded to group assignment". }\end{array}$ \\
\hline
\end{tabular}

White 2002

\begin{tabular}{|c|c|c|}
\hline Methods & \multicolumn{2}{|c|}{$\begin{array}{l}\text { Randomization by computer-generated random number table. All patients were told that the ReliefBand } \\
\text { acu-stimulation device produces a sensation which they may or may not feel to minimize bias. Patients } \\
\text { recorded outcome measures in a patient diary. }\end{array}$} \\
\hline Participants & \multicolumn{2}{|c|}{$\begin{array}{l}120 \text { Adults undergoing elective plastic surgery. Excluded: antiemetic medication within } 24 \text { hours before } \\
\text { surgery, pregnancy, using permanent cardiac pacemaker, previous experience with acu-stimulation } \\
\text { treatment, experiencing vomiting or retching within } 24 \text { hours before surgery. No patients withdrew } \\
\text { before discharge from hospital, } 5 \text { patients withdrew from study at } 72 \text { hours follow up. }\end{array}$} \\
\hline Interventions & \multicolumn{2}{|c|}{$\begin{array}{l}\text { Group 1: ondansetron } 4 \mathrm{mg} \text { and inactive acu-stimulation device at P6 acupoint on arrival in the recovery } \\
\text { room. Device worn for } 72 \text { hours after surgery. } \\
\text { Group 2: saline } 2 \mathrm{~mL} \text { and active acu-stimulation device at P6 acupoint on arrival in the recovery room. } \\
\text { Device worn for } 72 \text { hours after surgery. } \\
\text { Group 3: ondansetron } 4 \mathrm{mg} \text { and active acu-stimulation device at P6 acupoint on arrival in the recovery } \\
\text { room. Device worn for } 72 \text { hours after surgery. }\end{array}$} \\
\hline Outcomes & \multicolumn{2}{|c|}{$\begin{array}{l}\text { Nausea (0-hospital discharge), vomiting (0-hospital discharge), risk of rescue antiemetic drug, side } \\
\text { effects. }\end{array}$} \\
\hline Notes & \multicolumn{2}{|c|}{$\begin{array}{l}\text { Rescue antiemetic was metoclopramide } 10 \mathrm{mg} \text { IV if persistent nausea or vomiting, or retching lasting } \\
\text { more than } 10 \text { minutes. Group } 3 \text { data were not used for data analysis. No swelling at wrist or erythema } \\
\text { reported. No outcome measures }(0-72 \mathrm{~h}) \text { given in the paper. }\end{array}$} \\
\hline \multicolumn{3}{|l|}{ Risk of bias } \\
\hline Item & Authors' judgement & Description \\
\hline Adequate sequence generation? & Yes & $\begin{array}{l}\text { "Patients were randomly assigned to one of three } \\
\text { treatment groups using a computer-generated random } \\
\text { number table...". }\end{array}$ \\
\hline Allocation concealment? & Unclear & Insufficient information. \\
\hline $\begin{array}{l}\text { Incomplete outcome data } \\
\text { addressed? All outcomes }\end{array}$ & Yes & No missing data reported for 120 patients randomized. \\
\hline Free of selective reporting? & Yes & All expected outcomes were reported. \\
\hline Free of other bias? & Yes & $\begin{array}{l}\text { Baseline characteristics were comparable. "The three } \\
\text { treatment groups were comparable with respect to } \\
\text { demographic characteristics, pre-existing risk factors } \\
\text { for development of PONV, and preoperative nausea } \\
\text { scores (Table 1)". }\end{array}$ \\
\hline Blinding of patients? All outcomes & Yes & $\begin{array}{l}\text { All patients were told that the ReliefBand acu- } \\
\text { stimulation device produces a sensation which they } \\
\text { may or may not feel to minimize bias. Patients recorded } \\
\text { outcome measures in a patient diary. }\end{array}$ \\
\hline $\begin{array}{l}\text { Blinding of healthcare providers? } \\
\text { All outcomes }\end{array}$ & Unclear & Insufficient information. \\
\hline $\begin{array}{l}\text { Blinding of outcome assessor? All } \\
\text { outcomes }\end{array}$ & Yes & $\begin{array}{l}\text { All patients were told that the ReliefBand acu- } \\
\text { stimulation device produces a sensation which they } \\
\text { may or may not feel to minimize bias. Patients recorded } \\
\text { outcome measures in a patient diary. }\end{array}$ \\
\hline
\end{tabular}




\begin{tabular}{|c|c|c|}
\hline Methods & \multicolumn{2}{|c|}{$\begin{array}{l}\text { Method of allocation concealment not given. Recovery room nurses collected data. No antiemetic drugs } \\
\text { were given in the recovery room. }\end{array}$} \\
\hline Participants & \multicolumn{2}{|c|}{120 women undergoing gynaecological laparoscopy. } \\
\hline Interventions & \multicolumn{2}{|c|}{$\begin{array}{l}\text { Group 1: acupuncture group included patients given an injection of } 0.2 \mathrm{~mL} 50 \% \text { glucose in water into P6 } \\
\text { acupoint before extubation. } \\
\text { Group 2: antiemetic group was droperidol } 20 \mathrm{ug} / \mathrm{kg} \mathrm{IV} \text { on induction of anaesthesia. } \\
\text { Group 3: no treatment. }\end{array}$} \\
\hline Outcomes & \multicolumn{2}{|c|}{ Vomiting $(0-3 \mathrm{~h})$, side effects of acupuncture. } \\
\hline Notes & \multicolumn{2}{|c|}{$\begin{array}{l}\text { Reference group received no treatment and was not included in data analysis. Pain at acupoint site } \\
\text { noted. }\end{array}$} \\
\hline \multicolumn{3}{|l|}{ Risk of bias } \\
\hline Item & Authors' judgement & Description \\
\hline Adequate sequence generation? & Unclear & Insufficient information. \\
\hline Allocation concealment? & Unclear & Insufficient information. \\
\hline $\begin{array}{l}\text { Incomplete outcome data } \\
\text { addressed? All outcomes }\end{array}$ & Yes & No missing data recorded for 120 patients analysed. \\
\hline Free of selective reporting? & No & Nausea was not reported. \\
\hline Free of other bias? & Yes & $\begin{array}{l}\text { Baseline characteristics were comparable. "There was } \\
\text { no statistically significant differences in age, weight, } \\
\text { duration of anesthesia or amount of fluid given among } \\
\text { the three groups of patients (Table 1)". }\end{array}$ \\
\hline Blinding of patients? All outcomes & Unclear & Insufficient information. \\
\hline $\begin{array}{l}\text { Blinding of healthcare providers? } \\
\text { All outcomes }\end{array}$ & Unclear & Insufficient information. \\
\hline $\begin{array}{l}\text { Blinding of outcome assessor? All } \\
\text { outcomes }\end{array}$ & Unclear & Insufficient information. \\
\hline \multicolumn{3}{|l|}{ Yentis 1992} \\
\hline Methods & \multicolumn{2}{|c|}{$\begin{array}{l}\text { Method of allocation concealment not given. Medical staff, children and parents were blinded to } \\
\text { treatment groups. No specific details about who collected the outcomes and whether or not they were } \\
\text { blinded to treatment allocation. }\end{array}$} \\
\hline Participants & \multicolumn{2}{|c|}{$\begin{array}{l}90 \text { Children ( } 1 \text { to } 16 \text { years) undergoing strabismus surgery. One patient in each of the three groups } \\
\text { could not be contacted after surgery. }\end{array}$} \\
\hline Interventions & \multicolumn{2}{|c|}{$\begin{array}{l}\text { Group 1: acupuncture at P6 acupoint on right wrist with } 5 \text { minutes of manual stimulation after induction } \\
\text { of anaesthesia. } \\
\text { Group 2: antiemetic group had } 0.075 \mathrm{mg} / \mathrm{kg} \text { droperidol IV after induction of anaesthesia. } \\
\text { Group 3: acupuncture (as in Group 1) and droperidol (as in Group 2) treatment. }\end{array}$} \\
\hline Outcomes & \multicolumn{2}{|c|}{ Vomiting $(0-48 \mathrm{~h})$, risk of rescue antiemetic drug, side effects of treatment. } \\
\hline Notes & \multicolumn{2}{|c|}{$\begin{array}{l}\text { Rescue antiemetic was dimenhydrinate IM. Restlessness more frequent in droperidol group than } \\
\text { acupuncture group. Risk of vomiting before discharge from hospital also reported in paper. Group } 3 \\
\text { data was not used in the data analysis. }\end{array}$} \\
\hline \multicolumn{3}{|l|}{ Risk of bias } \\
\hline Item & Authors' judgement & Description \\
\hline Adequate sequence generation? & Unclear & Insufficient information. \\
\hline Allocation concealment? & Unclear & Insufficient information. \\
\hline $\begin{array}{l}\text { Incomplete outcome data } \\
\text { addressed? All outcomes }\end{array}$ & Yes & $\begin{array}{l}\text { One patient in each group lost to follow up. Comment: } \\
\text { unlikely to bias summary estimate. }\end{array}$ \\
\hline Free of selective reporting? & Unclear & $\begin{array}{l}\text { Nausea was not reported because it may have been } \\
\text { difficult to assess in younger children. }\end{array}$ \\
\hline Free of other bias? & Yes & $\begin{array}{l}\text { Baseline characteristics were comparable. "Age, } \\
\text { weight, number of muscles repaired and duration of } \\
\text { anaesthesia did not differ among the groups (Table)". }\end{array}$ \\
\hline
\end{tabular}




\begin{tabular}{l|l|l} 
Blinding of patients? All outcomes & Yes & $\begin{array}{l}\text { "Whether or not patients received droperidol, both } \\
\text { treatments or acupuncture alone, was unknown to the } \\
\text { staff, the patients and their parents". }\end{array}$ \\
\hline $\begin{array}{l}\text { Blinding of healthcare providers? } \\
\text { All outcomes }\end{array}$ & Yes & $\begin{array}{l}\text { "Whether or not patients received droperidol, both } \\
\text { treatments or acupuncture alone, was unknown to the } \\
\text { staff, the patients and their parents". }\end{array}$ \\
\hline $\begin{array}{l}\text { Blinding of outcome assessor? All } \\
\text { outcomes }\end{array}$ & Unclear & Insufficient information. \\
\hline
\end{tabular}

Zarate 2001

Methods

Assignment of treatment by computer-generated random number table. All patients were told before the operation that the ReliefBand produces a sensation which they may or may not feel to minimize bias. Recovery room nurses were unaware of treatment groups.

Participants

250 Adults undergoing laparoscopic cholecystectomy. Excluded: patients who had taken antiemetic, glucocorticosteroids, or psychoactive medication within 24 hours before the operation; were pregnant; had an implanted cardiac pacemaker or defibrillator device; or had experienced vomiting or retching within 24 hours before surgery. 29 adults were excluded because of protocol violations.

Interventions

Group 1: ReliefBand (watch-like acu-stimulation device) positioned at P6 acupoint before the end of surgery. The device was set to deliver a $25 \mathrm{~mA}$ stimulus at $31 \mathrm{~Hz}$. Patients wore the device for 9 hours after surgery.

Group 2: ReliefBand with no acu-stimulation positioned at P6 acupoint before end of surgery, worn up to 9 hours after surgery.

Group 3: ReliefBand with no acu-stimulation positioned at the dorsal aspect of the wrist before end of surgery, worn up to 9 hours after surgery.

\begin{tabular}{|c|c|c|}
\hline Outcomes & \multicolumn{2}{|c|}{$\begin{array}{l}\text { Nausea ( } 0 \text {-arrival in recovery room), vomiting }(0 \text {-arrival in recovery room), risk of rescue antiemetic } \\
(0-2 \mathrm{~h}) \text {, side effects of wristband. Rescue antiemetics were droperidol } 0.625 \mathrm{mg} \text { IV and ondansetron } 4 \\
\text { mg IV. }\end{array}$} \\
\hline Notes & \multicolumn{2}{|c|}{$\begin{array}{l}\text { Group } 2 \text { and Group } 3 \text { were considered as the sham control group for data analysis. Although the } \\
\text { ReliefBand devices were identical in appearance, their placement on the dorsal side of the wrist would } \\
\text { have suggested that the patients were in Group } 3 \text {. Outcomes also evaluated at } 45,90,120,240,360 \text { and } \\
540 \text { min after surgery. No cumulative data recorded (requested data from authors but no reply). Side } \\
\text { effects of wristbands were mild cutaneous irritation with erythema. }\end{array}$} \\
\hline \multicolumn{3}{|l|}{ Risk of bias } \\
\hline Item & Authors' judgement & Description \\
\hline Adequate sequence generation? & Yes & $\begin{array}{l}\text { "Outpatients who had been fasted overnight were } \\
\text { randomly assigned to one of three treatment groups } \\
\text { (groups T, S, and P) with a computer-generated random } \\
\text { number table". }\end{array}$ \\
\hline Allocation concealment? & Unclear & Insufficient information. \\
\hline $\begin{array}{l}\text { Incomplete outcome data } \\
\text { addressed? All outcomes }\end{array}$ & Yes & $\begin{array}{l}\text { Reasons for withdrawals were given. No missing data } \\
\text { recorded for } 221 \text { patients analysed. }\end{array}$ \\
\hline Free of selective reporting? & Yes & All expected outcomes reported. \\
\hline Free of other bias? & Yes & $\begin{array}{l}\text { Baseline characteristics were comparable. "The three } \\
\text { treatment groups were comparable demographically } \\
\text { and with respect to their histories of PONV and motion } \\
\text { sickness, baseline nausea score, duration of surgery, } \\
\text { and the time the acu-stimulation device was applied } \\
\text { before the end of surgery (Table 1)". }\end{array}$ \\
\hline Blinding of patients? All outcomes & Yes & $\begin{array}{l}\text { Authors took adequate steps to make interventions } \\
\text { appear similar. "To minimize bias resulting from the } \\
\text { presence or absence of the electrical stimulation, all } \\
\text { patients were told before the operation that the } \\
\text { ReliefBand produces a sensation which 'they might or } \\
\text { might not feel". }\end{array}$ \\
\hline $\begin{array}{l}\text { Blinding of healthcare providers? } \\
\text { All outcomes }\end{array}$ & Yes & $\begin{array}{l}\text { "The recovery room nursing staff were unaware of the } \\
\text { acu-stimulation treatment group to which the patient } \\
\text { had been assigned". }\end{array}$ \\
\hline $\begin{array}{l}\text { Blinding of outcome assessor? All } \\
\text { outcomes }\end{array}$ & Yes & $\begin{array}{l}\text { "The recovery room nursing staff were unaware of the } \\
\text { acu-stimulation treatment group to which the patient } \\
\text { had been assigned". }\end{array}$ \\
\hline
\end{tabular}


Characteristics of excluded studies [ordered by study ID]

\begin{tabular}{|c|c|}
\hline Study & Reason for exclusion \\
\hline Agarwal 2005 & P6 acupoint stimulation not used. Authors used Korean hand acupressure point K-D2 in the study. \\
\hline Al-Sadi 1997 & No sham treatment group used. Control was defined as no intraoperative acupuncture needle at P6 acupoint. \\
\hline Alkaissi 2005 & Patients did not undergo surgery. \\
\hline Cekmen 2007 & P6 acupoint stimulation not used. Authors used transcutaneous electrical nerve stimulation on neck and mastoid area. \\
\hline Chen 2005 & $\begin{array}{l}\text { Not randomized controlled trial. First } 52 \text { subjects were in the control group (no treatment) and remaining } 52 \text { patients were } \\
\text { in the acupressure group. }\end{array}$ \\
\hline Coloma 2002 & Treatment of established postoperative nausea and vomiting. \\
\hline Dundee 1988 & Risk of nausea and vomiting were not reported separately. \\
\hline Dundee 1991 & Two different forms of P6 stimulation (acupuncture + saline, acupuncture $+1 \%$ lidocaine). No sham treatment group used. \\
\hline Fan 1997 & Risk of nausea and vomiting were not reported separately. \\
\hline Fry 1986 & $\begin{array}{l}\text { No sham treatment group used. Control was defined as no acupressure treatment. Patients did not know that they were in } \\
\text { the trial. }\end{array}$ \\
\hline Но 2006 & Prevention of intraoperative nausea and vomiting. \\
\hline Kabalak 2005 & Both P6 and CV 13 acupoints used. No treatment was given to the control group. \\
\hline Khan 2004 & Risks of nausea and vomiting were not reported separately. \\
\hline Kim 2002 & $\begin{array}{l}\text { Control was defined as an inactive capsicum plaster tape fixed at the Korean hand acupuncture point K-D2 point of both } \\
\text { hands. }\end{array}$ \\
\hline McMillan 1994 & $\begin{array}{l}\text { All transcutaneous electrical stimulation at P6 acupoint groups received antiemetics. Risk of nausea and vomiting were not } \\
\text { reported separately for placebo transcutaneous electrical stimulation and transcutaneous electrical stimulation groups. }\end{array}$ \\
\hline Ming 2002 & Stimulation of both $\mathrm{P} 6$ and $\mathrm{H} 7$ acupoints. \\
\hline Phillips 1994 & No sham treatment group used. No specific details of the type of antiemetic drug used as control. \\
\hline Schneider 2005 & Same study as Streitberger et al (2004). Incidence of postoperative nausea and vomiting were not reported separately. \\
\hline Schwager 1996 & Both P6 and Li4 acupoints stimulated. \\
\hline Shyr 1990 & Control was defined as no acupuncture at P6 acupoint. \\
\hline Somri 2001 & Both P6 and CV13 acupoints used. \\
\hline Stein 1997 & Prevention of intraoperative nausea and vomiting. \\
\hline Weightman 1987 & No sham treatment group used. Control was defined as no acupuncture at P6 acupoint after induction of anaesthesia. \\
\hline White 2005 & $\begin{array}{l}\text { This study compared three prophylactic acu-stimulation treatments: preoperative, postoperative, and both preoperative and } \\
\text { postoperative. No sham treatment group used for both preoperative and postoperative acu-stimulation. }\end{array}$ \\
\hline Windle 2001 & $\begin{array}{l}\text { Quasi-experimental design. Randomization done on every third patient who agreed to participate and met study criteria. } \\
\text { Retrospective chart review was used to estimate the risk of vomiting. Risk of nausea and vomiting were not considered } \\
\text { separately, and results were not presented in the paper. }\end{array}$ \\
\hline Yentis 1991 & No sham treatment group used. Control was no acupuncture treatment at P6 acupoint. \\
\hline Yentis 1998 & $\begin{array}{l}\text { This study compared acupuncture given before induction, after induction and in the recovery room. No sham treatment or } \\
\text { antiemetic drug group for comparison. }\end{array}$ \\
\hline
\end{tabular}

